UNIVERSIDADE DE SÃO PAULO

ESCOLA DE ENFERMAGEM DE RIBEIRÃO PRETO

\title{
RECONSTRUINDO A TRAJETÓRIA DE MÃES DE CRIANÇAS QUE MORRERAM POR TÉTANO NEONATAL EM MINAS GERAIS
}

Lúcio José Vieira

Ribeirão Preto 2005 


\title{
Lúcio José Vieira
}

\section{RECONSTRUINDO A TRAJETÓRIA DE MÃES DE CRIANÇAS QUE MORRERAM POR TÉTANO NEONATAL EM MINAS GERAIS}

\begin{abstract}
Tese apresentada à Escola de Enfermagem de Ribeirão Preto, da Universidade de São Paulo, para a obtenção do Título de Doutor em Enfermagem de Saúde Pública. Trabalho inserido na linha de pesquisa Práticas, Saberes e Políticas de Saúde, do Programa de PósGraduação de Enfermagem em Saúde Pública, do Departamento de Enfermagem MaternoInfantil e Saúde Pública.
\end{abstract}

Orientadora: $\operatorname{Prof}^{\mathrm{a}} \operatorname{Dr}^{\mathrm{a}}$ Maria Helena Pessini de Oliveira

Ribeirão Preto 


\begin{abstract}
AUTORIZO A REPRODUÇÃO E DIVULGAÇÃO TOTAL OU PARCIAL DESTE TRABALHO POR QUALQUER MEIO CONVENCIONAL OU ELETRÔNICO, PARA FINS DE ESTUDO E PESQUISA, DESDE QUE CITADA A FONTE.
\end{abstract}

FICHA CATALOGRÁFICA

Vieira, Lúcio José

Reconstruindo a trajetória de mães de crianças que morreram por tétano neonatal em Minas Gerais. Ribeirão Preto, 2005.139 f. : il.

Tese de Doutorado, apresentada à Escola de Enfermagem de Ribeirão Preto/USP - Área de concentração: Enfermagem em Saúde Pública.

Orientadora: Oliveira, Maria Helena Pessini de.

1. Tétano. 2. Doenças do recém nascido. 3. Fatores de risco. 


\title{
FOLHA DE APROVAÇÃO
}

\author{
Lúcio José Vieira
}

\section{Reconstrução da trajetória de mães de crianças que morreram por tétano neonatal em Minas Gerais.}
Tese apresentada à Escola de Enfermagem de Ribeirão Preto, da Universidade de São Paulo, para a obtenção do Título de Doutor.
Área de concentração: Enfermagem em Saúde Pública

Aprovado em:

Banca Examinadora:

Prof $^{\mathrm{a}}$ Dr $^{\mathrm{a}}$ Maria Helena Pessini de Oliveira - Orientadora

Instituição: Escola de Enfermagem de Ribeirão Preto - USP

Assinatura:

Prof $^{\mathrm{a}} \mathrm{Dr}^{\mathrm{a}}$ Ione Carvalho Pinto

Instituição: Escola de Enfermagem de Ribeirão Preto - USP

Assinatura:

Prof $^{a}$ Dr $^{\mathrm{a}}$ Maria das Graças Bonfim de Carvalho

Instituição: Escola de Enfermagem de Ribeirão Preto - USP

Assinatura:

Prof. Dr. Fernando Lefèvre

Instituição: Faculdade de Saúde Pública - USP

Assinatura:

Prof. Dr. Romeu Gomes

Instituição: Instituto Fernandes Figueira - Fundação Oswaldo Cruz

Assinatura: 
Dedico este trabalho aos meus amores: Regina, Maria Alice e Rafael. 


\section{AGRADECIMENTOS}

A DEUS que me permitiu existir e me propiciou oportunidades de crescimento.

Aos meus pais, Antonio e Alice, que na sua simplicidade sempre estimularam o conhecimento e não mediram esforços para garantir minha formação universitária.

À Escola de Enfermagem da Universidade Federal de Minas Gerais, por intermédio do Departamento de Enfermagem Materno-Infantil e Saúde Pública, por ter-me possibilitado cursar este doutorado.

À Coordenação de Aperfeiçoamento de Pessoal de Nível Superior, pela concessão da bolsa do PICDT, a qual foi fundamental para a minha manutenção em Ribeirão Preto - SP.

À Professora $\mathrm{Dr}^{\mathrm{a}}$ Maria Helena Pessini de Oliveira, minha orientadora, que pacientemente me auxiliou nesta construção, respeitando meus limites e sempre me estimulando.

Às Professoras Dr ${ }^{\mathrm{a}}$ Ione Carvalho Pinto e $\mathrm{Dr}^{\mathrm{a}}$ Maria das Graças Bonfim de Carvalho, que participaram da banca de qualificação, pelas importantes contribuições na realização desta investigação.

Aos docentes e servidores do Departamento de Enfermagem Materno-Infantil e Saúde Pública, servidores da Seção de Pós-Graduação e demais servidores da Escola de Enfermagem de Ribeirão Preto - USP.

Aos alunos, colegas e amigos da Pós-Graduação da Escola de Enfermagem de Ribeirão Preto - USP.

À Deolinda e a Lourdes, pelo carinho, pela amizade e pelo apoio na localização dos periódicos, dissertações e teses.

Ao Programa de Aperfeiçoamento de Ensino da Universidade de São Paulo, pela oportunidade de aprimoramento docente. 
À Fundação de Amparo à Pesquisa do Estado de São Paulo, cujo apoio financeiro tornou viável a realização desta pesquisa.

À Dr ${ }^{\mathrm{a}}$ Valéria Melo Rodrigues de Oliveira, Superintendente de Epidemiologia da Secretaria de Estado da Saúde de Minas Gerais.

À Lea Dulce de Souza, Referência Técnica em Imunização da Secretaria de Estado da Saúde de Minas Gerais.

À Dr ${ }^{\mathrm{a}}$ Regina Coeli Magalhães Rodrigues, Referência Técnica de Tétano Acidental e Tétano Neonatal da Secretaria de Estado da Saúde de Minas Gerais.

Aos diretores e servidores das Diretorias de Ações Descentralizadas de Saúde; aos servidores e secretários municipais de saúde dos municípios de residência das mães entrevistadas.

À Prof ${ }^{\mathrm{a}}$ Dr $^{\mathrm{a}}$ Maria Rizoneide Negreiros de Araújo, Diretora da Atenção Básica/Programa Saúde da Família da Secretaria de Estado da Saúde de Minas Gerais.

À Dr ${ }^{\mathrm{a}}$ Márcia Rovena de Oliveira, Referência Técnica da Saúde da Mulher da Secretaria de Estado da Saúde de Minas Gerais.

Às mães entrevistadas, pela disponibilidade e confiança, sem as quais este trabalho não se concretizaria.

A todos que fizeram e fazem parte desta trajetória. 


\section{RESUMO}

\section{VIEIRA, L. J. Reconstruindo a trajetória de mães de crianças que morreram por tétano}

neonatal em Minas Gerais. 2005. 139f. Tese de Doutorado - Escola de Enfermagem de Ribeirão Preto, Universidade de São Paulo, Ribeirão Preto, 2005.

Trata-se de uma pesquisa com o objetivo de compreender o adoecimento pelo tétano neonatal, a partir da análise da trajetória de um grupo de 19 mães de crianças que morreram em conseqüência da doença no período compreendido entre 1997 e 2002, em municípios do Estado de Minas Gerais, Brasil. Para a análise, foram utilizadas Políticas de Assistência à Saúde da Mulher, Imunização e a Estratégia de Saúde da Família. Os dados foram obtidos em entrevistas semi-estruturadas e nos registros secundários do Cartão de Vacina e do Cartão da Gestante. A metodologia adotada foi de natureza quantitativa e qualitativa, com enfoque nas representações sociais sobre a experiência da doença e o risco de adoecimento. Para a análise das entrevistas, utilizou-se o instrumento do discurso do sujeito coletivo. As mulheres, em sua maioria, são multíparas em idade fértil, desconhecem a doença e seus mecanismos de prevenção, embora relatem as principais manifestações clínicas do tétano neonatal associando-o ao mal-de-sete-dias. São evidentes as práticas de tratamento inadequado do coto umbilical utilizadas pelas mulheres, sedimentadas no risco potencial para a doença, a irregularidade do pré-natal, a ausência ou a administração de doses insuficientes de vacina para a proteção do tétano neonatal e do tétano acidental, e procedimentos pós-parto domiciliar impróprios utilizados pelas parteiras ou curiosas. Observou-se, pelas falas das mães, a presença da crendice sobre os cuidados com o coto umbilical e a falha dos serviços no processo de educação para a saúde. Urge implementar esforços estratégicos específicos, direcionados à vigilância epidemiológica, à capacitação de parteiras e aos profissionais de saúde, incrementar serviços de pré-natal e ampliar a cobertura vacinal para as mulheres, principalmente nas regiões de onde provêm os casos da pesquisa, contribuindo, assim, para a eliminação da doença.

DESCRITORES: vacinação; cuidado pré-natal; tétano; recém-nascido; epidemiologia; fatores de risco. 


\section{RESUMEN}

VIEIRA, L. J. Recontruyendo la trayectoria de madres de niños que morieron portetanos neonatal en la provincia de Minas Gerais. 2005. 139f. Tesis Doctorado - Escuela de Enfermería de Ribeirão Preto, Universidad de São Paulo, Ribeirão Preto, 2005.

La finalidad de esta investigación es comprender el padecimiento por el tétano neonatal, a partir del análisis de la trayectoria de un grupo de 19 madres de niños que murieron debido a la enfermedad en el período entre 1997 y 2002, en municipios del Estado de Minas Gerais, Brasil. Para el análisis utilizamos Políticas de Atención a la Salud de la Mujer, Inmunización y la Estrategia de Salud de la Familia. La recopilación de datos fue mediante entrevistas semiestructuradas y en los registros secundarios de la Tarjeta de Vacuna y de la Tarjeta de la Mujer Embarazada. La metodología adoptada fue del tipo cuantitativo y cualitativo, con enfoque en las representaciones sociales acerca de la experiencia de la enfermedad y el riesgo de padecimiento. Para el análisis de las entrevistas, utilizamos el instrumento del discurso del sujeto colectivo. La mayoría de las mujeres son multíparas en edad fértil, desconocen la enfermedad y sus mecanismos de prevención, aunque relaten las principales manifestaciones clínicas del tétano neonatal asociándolo al "mal de los siete días. Se quedan evidentes las prácticas de tratamiento inadecuado del cordón umbilical utilizadas por las mujeres, sedimentadas en el riesgo potencial para la enfermedad, la irregularidad del prenatal, la ausencia o la administración de dosis insuficientes de vacuna para la protección del tétano neonatal y del tétano accidental, e procedimientos tras el parto domiciliario impropios utilizados por las parteras o comadres. Fue observado mediante las hablas de las madres la presencia de la creencia popular sobre los cuidados con el cordón umbilical y la deficiencia de los servicios en el proceso de educación para la salud. Urge implementar esfuerzos estratégicos específicos, dirigidos a la vigilancia epidemiológica, a la capacitación de parteras y profesionales de salud, incrementar servicios de prenatal y ampliar la cobertura vacunal para las mujeres, principalmente en las regiones de donde provienen los casos de la investigación, contribuyendo así para la eliminación de la enfermedad.

DESCRIPTORES: vacunación; atención prenatal; tétano; recién nacido; epidemiología; factores de riesgo. 


\begin{abstract}
VIEIRA, L. J. Rebuilding the experience of mothers of children who died due to neonatal tetanus in the state of Minas Gerais.2005. 139f. Doctoral Thesis - Ribeirão Preto College of Nursing, University of São Paulo, Ribeirão Preto, 2005.

This research aimed to understand the illness caused by neonatal tetanus, based on the analysis of a group of 19 mothers' histories involving children who died of the disease in communities located in the State of Minas Gerais, Brazil, between 1997 and 2002. The analysis was based on Women's Health Care and Immunization Policies and the Family Health Strategy. Data were collected through semistructured interviews and secondary records from the Vaccination Card and the Pregnant Woman's Card. A quantitative and qualitative methodology was adopted, focusing on the social representations about the disease experience and the risk of getting ill. The interviews were analyzed on the basis of collective subject discourse. Most women were of fertile age and multiparous and did not know about the disease and its prevention mechanisms, although they reported on the main clinical signs of neonatal tetanus, associating it with the "seven-day disease". This study revealed the women's use of inadequate practices for treating the umbilical cord stump, based on the potential risk of catching the disease, irregular antenatal treatment, the absence or administration of insufficient doses of the vaccine to protect against neonatal and accidental tetanus, and inappropriate post-home delivery procedures used by midwifes. The mothers' discourse revealed the presence of popular beliefs on care related to the umbilical cord stump and the services' deficiency in the health education process. There is an urgent need to implement specific strategic efforts, aimed at epidemiological supervision, the training of midwifes and health professionals, and to increase prenatal services and expand vaccination coverage for women, mainly in the research cases' regions of origin, thus contributing to the elimination of this disease.
\end{abstract}

DESCRIPTORS: vaccination; prenatal care; tetanus; newborn; epidemiology; risk factors. 


\section{LISTA DE FIGURAS}

Figura 1 - Distribuição das 27 Diretorias de Ações Descentralizadas de Saúde do Estado de Minas Gerais - 2004

Figura 2 - Recém-nascido filho de mãe adolescente do município de Governador Valadares - Minas Gerais - 2003

Figura 3 - Divisão territorial, segundo regiões administrativas do Estado de Minas Gerais - 2004

Figura 4 - Ilustração da obra de Rösslin, representando um parto de 1513

Figura 5 - Cartaz de divulgação da vacina dT para gestantes e mulheres em idade fértil

Figura 6 - Municípios de Minas Gerais por local de residência, dos 19 casos de óbito por tétano neonatal (1997-2002), cujas mães foram entrevistadas.

Figura 7 - Moradia típica das mães entrevistadas - Minas Gerais - 2004. 


\section{LISTA DE GRÁFICOS}

Gráfico 1 - Coeficiente de mortalidade materna por 100.000 nascidos vivos por triênio, no Brasil, entre 1980 e 2000.

Gráfico 2 - Casos de tétano neonatal confirmados por ano, no Brasil, entre 1986 e 2002

Gráfico 3 - Casos de tétano neonatal confirmados em Minas Gerais entre 1993 e 2004

Gráfico 4 - Número de equipes do Programa Saúde da Família e de municípios implantados em Minas Gerais entre 1995 e 2004 


\section{LISTA DE QUADROS}

Quadro 1 - Esquema de vacinação antitetânica para gestantes.................................

Quadro 2 - Algumas características da assistência pré-natal dos nascidos vivos nos últimos cinco anos anteriores da PNDS/96 


\section{LISTA DE TABELAS}

Tabela 1 - Situação das mães em relação à vacina dupla, tendo como referência o momento da ocorrência do caso de óbito por tétano neonatal (TNN) e no momento da entrevista - Minas Gerais - 1997 a 2002 ......................... 


\section{ABREVIATURAS E SIGLAS}

ACS

BCG

BNDES

CEME

CENEPI

CLAP

DADS

DATASUS

DPT

DRS

dT

FAPESP

FAT

FSESP

FUNASA

IBGE

IDH

MS

NOAS

OMS

ONGS

OPV

PAB

PACS

PAI

PAISM

PHPN

PNDS
Agente Comunitário de Saúde

Bacilo de Calmette Guérin - Vacina contra a tuberculose

Banco Nacional de Desenvolvimento Econômico e Social

Central de Medicamentos

Centro Nacional de Epidemiologia

Centro Latino Americano de Perinatologia e Desenvolvimento

Humano

Diretoria de Ações Descentralizadas de Saúde

Processamento de Dados do Sistema Único de Saúde

Difteria, Coqueluche (Pertusis) e Tétano - vacina tríplice bacteriana

Diretoria Regional de Saúde

Difteria e Tétano - vacina dupla uso adulto

Fundação de Amparo à Pesquisa do Estado de São Paulo

Fundo de Apoio ao Trabalhador

Fundação Serviços de Saúde Pública

Fundação Nacional de Saúde

Fundação Instituto Brasileiro de Geografia e Estatística

Índice de Desenvolvimento Humano

Ministério da Saúde

Norma Operacional da Assistência à Saúde

Organização Mundial da Saúde

Organizações Não Governamentais

Oportunidades Perdidas de Vacinação

Piso da Atenção Básica

Programa de Agentes Comunitários de Saúde

Programa Ampliado de Imunização

Programa de Assistência Integral à Saúde da Mulher

Programa de Humanização no Pré-natal e no Nascimento

Pesquisa Nacional de Demografia e Saúde 
PNI

PRONAN

PSF

$\mathrm{RN}$

SES-MG

SIA

SIAB

SIAPI

SIM

SINASC

SISHIPERDIA

SISPRENATAL

SNABS

SUS

TA

TNN

TT

UFMG

UNICEF

USP

WHO
Programa Nacional de Imunização

Programa Nacional de Alimentação e Nutrição

Programa Saúde da Família

Recém-nascido

Secretaria de Estado da Saúde de Minas Gerais

Sistema de Informações Ambulatoriais

Sistema de Informação da Atenção Básica

Sistema de Informação e Avaliação do Programa de Imunização

Sistema de Informação de Mortalidade

Sistema de Informação Sobre Nascidos Vivos

Sistema de Cadastramento e Acompanhamento de Hipertensos e

Diabéticos

Sistema de Acompanhamento de Pré-natal

Secretaria Nacional de Ações Básicas de Saúde

Sistema Único de Saúde

Tétano Acidental

Tétano Neonatal

Toxóide Tetânico

Universidade Federal de Minas Gerais

Fundo das Nações Unidas para a Infância

Universidade de São Paulo

World Health Organization 


\section{SUMÁRIO}

Capítulo 1 - DEFINIÇÃO DO OBJETO DA PESQUISA.

Capítulo 2 - QUADRO DE ANÁLISE..

2.1 A assistência pré-natal no contexto da saúde da mulher.

2.2 O Programa Nacional de Imunização e sua contribuição na prevenção do tétano neonatal

2.3 O Programa Saúde da Família: uma estratégia para a atenção primária de saúde......

Capítulo 3 - METODOLOGIA. 67

3.1 Bases do estudo.. 68

3.2 Método de análise. 74

Capítulo 4 - RESULTADOS E DISCUSSÃO

CONSIDERAÇÕES FINAIS

ANEXOS

ANEXO 1 - Implantação, número de equipes e cobertura do Programa de Saúde da Família nos municípios onde ocorreram óbitos por tétano neonatal em Minas Gerais, entre 1997 e 2002

ANEXO 2 - Parecer da Aprovação do Comitê de Ética em Pesquisa da

UFMG

ANEXO 3 - Freqüência de tétano neonatal em Minas Gerais, entre 1997 e 2002, por DADS/município/ano.

ANEXO 4 - Roteiro de entrevista.

ANEXO 5 - Termo de consentimento pós-informado.. 


\section{Capítulo 1}

\section{DEFINIÇÃO DO OBJETO DA PESQUISA}

Minha experiência profissional sempre esteve ligada à área de Saúde Pública. Logo depois da graduação, cursei a Habilitação e a Especialização em Saúde Pública, pois já me identificava profissionalmente com a área em questão. Comecei a trabalhar na Diretoria Regional de Saúde de Pouso Alegre da Secretaria Estadual de Saúde de Minas Gerais (SESMG) ${ }^{1}$ onde atuei como supervisor técnico de uma das cinco microrregiões constituídas por municípios com características predominantemente rurais, dando suporte técnico de enfermagem nas outras quatro microrregiões da diretoria.

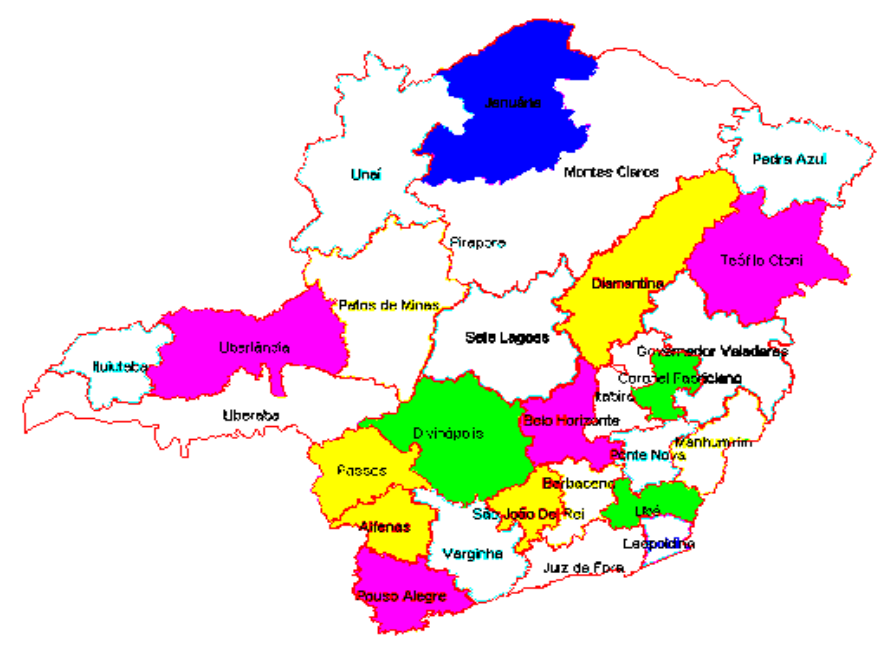

FIGURA 1 - Distribuição das 27 Diretorias de Ações Descentralizadas de Saúde do Estado de Minas Gerais - 2004.

\footnotetext{
${ }^{1}$ Na década de 1980 a Secretaria de Estado da Saúde de Minas Gerais era organizada em 23 Diretorias Regionais de Saúde (DRS), atendendo aos 756 municípios, sendo a DRS de Pouso Alegre responsável por 53 cidades, correspondendo a 7\% dos municípios mineiros. Atualmente são 27 Diretorias de Ações Descentralizadas de Saúde (DADS) no Estado, para um total de 853 municípios jurisdicionados.
} 
Atuo há 22 anos como docente da Escola de Enfermagem da UFMG, lecionando em disciplinas de saúde pública e saúde coletiva na graduação, especialização e na capacitação de auxiliares de enfermagem. Desenvolvo atividades relacionadas ao ensino, pesquisa e extensão em unidades básicas de saúde, ambulatórios e unidades de internação, entendendo que as atividades fins da Universidade devem estar sempre integradas e ser prioritariamente dirigidas para o bem-estar da população. Entre os conteúdos que leciono, incluem-se as doenças infecciosas, tratando-se de um dos temas mais polêmicos e desafiantes da saúde pública.

Durante as últimas décadas, se por um lado tive a oportunidade de acompanhar importantes conquistas no controle das doenças infecciosas, principalmente em relação às imunopreviníveis, deparei com a manutenção de muitas e o recrudescimento de outras, as quais já haviam sido controladas nos países desenvolvidos.

Por isso o tétano sempre foi para mim motivo de inquietação, por se tratar de uma doença infecciosa ainda presente no nosso país, para a qual existe o conhecimento para a sua prevenção e controle. Dentre suas duas modalidades, o tétano acidental (TA) e o tétano neonatal (TNN), ${ }^{2}$ esta última me inquietava mais ainda por sua elevada taxa de letalidade.

Em pleno século XXI, depois da erradicação da varíola, da poliomielite, do controle do sarampo e de outras doenças imunopreveníveis é uma contradição ainda deparar com a ocorrência de tétano neonatal no Brasil.

Isso me motivou a buscar esclarecimentos relacionados ao contexto do adoecimento, diante da possibilidade da prevenção por intermédio da vacina e da assistência pré-natal, o que resultou na dissertação de mestrado, intitulada Contribuição ao Estudo Epidemiológico do Tétano Neonatal no Estado de Minas Gerais de 1989 a 1996: um enfoque

\footnotetext{
${ }^{2}$ Tétano neonatal (TNN) é o acometimento de crianças até 28 dias, enquanto o tétano acidental (TA) é a denominação para as demais idades, ambos causados pelo mesmo agente bacteriano (Clostridium tetani).
} 
de risco (VIEIRA, 1998), que se trata de um estudo descritivo, analítico, horizontal e retrospectivo, utilizando o método epidemiológico clássico. Embora traga importantes contribuições, entre suas limitações apontamos a ausência da fala dos atores sociais que integram o cenário do problema, dentre os quais destacamos as mães das crianças que contraíram a doença.

Mesmo considerando as falhas no preenchimento dos registros, os resultados obtidos no estudo anterior revelaram a presença do tétano neonatal tanto em áreas rurais como urbanas, com predomínio de casos de procedência rural (59,4\%). Dos 70 casos estudados, ficou evidente o predomínio de casos e óbitos em municípios das Regiões Norte, Nordeste e do Jequitinhonha do Estado de Minas Gerais, áreas mais pobres e desprovidas de recursos, correspondendo a $63,5 \%$ do total. A maioria dos partos $(65,3 \%)$ ocorreu no domicílio e $60,8 \%$ foram assistidos por pessoa sem qualificação profissional, predominando as parteiras tradicionais, tendo $75,4 \%$ das mães informado não terem freqüentado o pré-natal.

Isso me despertou a curiosidade sobre as percepções das mães de crianças que contraíram tétano neonatal, por isso acredito que os depoimentos delas poderão trazer importantes contribuições para a melhor compreensão do problema e para o planejamento das ações para o controle da doença. A instigação me levou a continuar o processo de qualificação, agora, no doutorado do Programa de Pós-graduação de Enfermagem em Saúde Pública da Escola de Enfermagem de Ribeirão Preto - USP.

Tenho observado que apenas parte das gestantes e mulheres em idade fértil são vacinadas contra o tétano e que, apesar de dominar as estratégias de como vacinar e como fazer campanhas, as ações têm sido insuficientes para que as mães protejam seus filhos da doença por intermédio da vacinação.

Por um lado, podemos considerar que poucas gestantes procuram os postos de vacina e freqüentam o pré-natal, talvez em decorrência da dificuldade de acesso aos serviços 
de saúde, mas, por outro lado, muitas pessoas têm o conhecimento sobre a vacina, têm o acesso aos serviços, e, no entanto, negligenciam os modos de proteção à doença. Será que existe algo que influência na decisão da gestante de proteger-se da doença?

$\mathrm{Na}$ revisão bibliográfica realizada, os estudos sobre o tétano neonatal se relacionam à clínica e à epidemiologia clássica, não havendo pesquisas utilizando as representações sociais na temática.

Pressuponho que a possibilidade de o recém-nascido venha contrair tétano neonatal parece não fazer parte do cotidiano de muitas gestantes ou, quando está presente, aparece como distante, pois essas mulheres jamais pensaram na possibilidade de seus filhos adquirirem essa doença ou, se pensaram, a negligenciaram. "A vida cotidiana multiplica as ocasiões de risco por falta de atenção, negligência, desconhecimento de lugar, ou imperícia dos outros" (LE BRETON, 1995, p.7).

Neste estudo utilizo os conceitos de risco e fator de risco propostos pelo Centro Latino-Americano de Perinatologia e Desenvolvimento Humano (CLAP). Risco é a possibilidade de ocorrência de um resultado desfavorável, de um dano ou de um fenômeno indesejado. Dessa forma, estima-se o risco ou a probabilidade de que uma doença exista por meio dos coeficientes de incidência e prevalência. Considera-se fator de risco de um dano toda característica ou circunstância que acompanha um aumento da probabilidade de ocorrência do fator indesejado, sem que o dito fator tenha que intervir necessariamente em sua causalidade (CLAP, 1988).

Acredito que este estudo pode contribuir para o conhecimento sobre a doença, para melhoria das estratégias e medidas de controle relacionadas à obtenção de níveis adequados de cobertura pré-natal e vacinal, bem como apontar caminhos para que os profissionais de saúde e parteiras tradicionais participem efetivamente da prevenção individual e coletiva do tétano neonatal. 
A partir dessas considerações constitui objetivo do presente estudo: conhecer as representações sociais de mães de crianças que morreram por tétano neonatal, tendo como pano de fundo as políticas de assistência pré-natal e de imunizações.

Para isso, foi estabelecido um confronto entre essas representações sociais e as ações desses atores sociais, buscando:

1. identificar com as mães quais as possíveis medidas de proteção que elas utilizaram sobre a prevenção da doença;

2. categorizar os discursos das mães referente às possíveis medidas de proteção utilizadas na prevenção do tétano neonatal;

3. confrontar as representações sociais de mães de crianças que morreram por tétano neonatal com as políticas de assistência pré-natal e de imunizações.

O tétano neonatal é uma doença neurológica infecciosa aguda, caracterizada por espasmos e contrações musculares acompanhadas de convulsões, ocasionada por uma exotoxina do Clostridium tetani, potencialmente previnível, não contagiosa, de alta letalidade.

Nos países desenvolvidos, conseguiu-se controlar essa doença por meio da melhor atenção ao parto e puerpério e da cobertura universal com a vacinação antitetânica.

O médico François Gasse foi encarregado pela OMS, em 1986, de lançar uma campanha de erradicação do tétano neonatal no mundo em desenvolvimento. Juntamente com outros colegas de trabalho, produziu manuais de treinamento para capacitação de agentes de saúde para as ações de controle da doença e promoveu a criação de kits descartáveis para parteiras, contendo itens básicos de modo a proporcionar um parto mais seguro (OLA; D'AULAIRE, 2003).

A doença continua sendo um importante problema de saúde pública na maioria dos países subdesenvolvidos, sendo o tétano neonatal, em muitos países das Américas, 
responsável pela metade de todas as mortes neonatais e por $25 \%$ da mortalidade infantil (GALAZKA; STROH, 1986; BOLETIN DEL PAI, 1991; BRASIL, 1998b).

Depois do sarampo, o tétano neonatal é a doença imunoprevinível que determina o maior número de mortes, tendo sido estimados em 400 mil os óbitos causados pela doença em todo o mundo em 1992 (WHO, 1993).

Entre as diferentes medidas de prevenção, não há dúvida de que a imunização ativa é seguramente a mais eficaz e prática. O toxóide tetânico é uma das vacinas mais efetivas e seguras entre as de utilização rotineira, estimando-se o seu grau de proteção entre 85\% a 95\% (FOCACCIA; VERONESI, 1989; MIURA, 1994; BRASIL, 2001). Desse modo, havendo disponibilidade da vacina nos serviços de saúde, poder-se-ia considerar um contrasenso a existência do tétano em locais em que esses serviços existam e sejam acessíveis à população.

Apesar disso, a maioria dos estudos brasileiros indicam que o tétano neonatal é uma doença que acomete populações carentes, que não têm acesso aos serviços de saúde, incluindo os serviços obstétricos e de pré-natal (MENEGBEL et al., 1988; SCHRAMM; SANCHES; SZWARCWALD, 1996; VIEIRA, 1998). Assim, a morbidade e a mortalidade por tétano neonatal podem ser vistas como um indicador não apenas de diferenciais da situação de vida da população, mas também da acessibilidade, qualidade e utilização dos serviços de saúde materna e da extensão da cobertura pelo programa de vacinação.

A vacina antitetânica foi produzida pela primeira vez em 1923 por Ramon e tem sido submetida a vários aperfeiçoamentos quanto ao método de purificação da toxina e o aumento de sua capacidade antigênica pelo acréscimo de novos adjuvantes, particularmente os sais de alumínio (FOCACCIA; VERONESI, 1989). Excelentes resultados têm sido obtidos com a combinação do toxóide tetânico e outros antígenos, principalmente com o diftérico e o pertussis (Vacina Dupla - dT e Tríplice - DPT). 
O caso referente à foto da FIG. 2 a seguir é bastante ilustrativo da eficácia da vacina antitetânica, pois se trata de recém-nascido, filho de mãe adolescente que recebeu duas doses de dT, tendo feito pré-natal e sido orientada pelo Programa de Saúde da Família. Depois da alta hospitalar, por influência da bisavó e da avó, foi utilizada folha de mamona no coto umbilical dessa criança, a qual não adquiriu tétano possivelmente por ter recebido os anticorpos maternos.

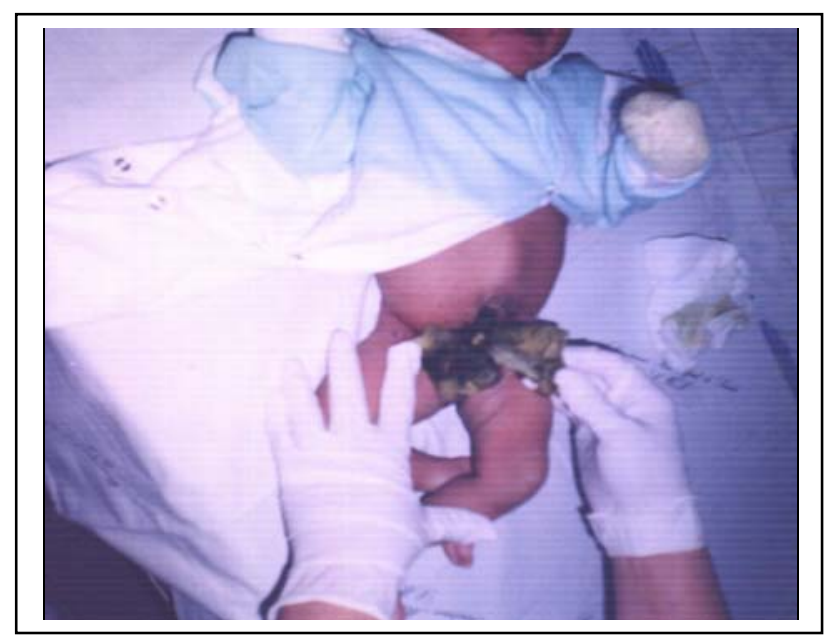

FIGURA 2 - Recém-nascido filho de mãe adolescente do município de Governador Valadares Minas Gerais - 2003.

O Manual de Normas de Vacinação do Ministério da Saúde (BRASIL, 2001) dispõe de orientações técnicas para a vacinação de mulheres em idade fértil e de gestantes em relação ao tétano, as quais sintetizo no QUADRO 1, a seguir: 


\section{QUADRO 1}

Esquema de vacinação antitetânica para gestantes

\begin{tabular}{l|l}
\hline \multicolumn{1}{c|}{ SITUAÇÃO VACINAL DA GESTANTE $^{3}$} & \multicolumn{1}{c}{ CONDUTA } \\
\hline $\begin{array}{l}\text { a) Não vacinada ou não sabe informar passado } \\
\text { vacinal. }\end{array}$ & $\begin{array}{l}\text { Três doses de TT ou dT com intervalos de oito } \\
\text { semanas, a serem aplicadas até o oitavo mês de } \\
\text { gestação. }\end{array}$ \\
$\begin{array}{l}\text { b) Com vacinação incompleta (tendo recebido } \\
\text { uma ou duas doses de DPT, dT ou TT). }\end{array}$ & $\begin{array}{l}\text { Completar o número de doses para três, } \\
\text { obedecendo ao intervalo de oito semanas e } \\
\text { aplicando até o oitavo mês de gestação. }\end{array}$ \\
$\begin{array}{l}\text { c) Vacinada com esquema completo. Última } \\
\text { dose há menos de cinco anos. }\end{array}$ & Nenhuma dose a aplicar. \\
$\begin{array}{l}\text { d) Vacinada com esquema completo. } \\
\text { Ultima dose há mais de cinco anos. }\end{array}$ & $\begin{array}{l}\text { Aplicar uma dose de reforço tão logo seja } \\
\text { possível. }\end{array}$ \\
\hline
\end{tabular}

Fonte: Manual de Normas de Vacinação do Ministério da Saúde, Brasil, 2001.

No caso de a atenção pré-natal ser iniciada em fase avançada da gestação, mas que permite a aplicação de duas doses com intervalos de oito semanas, o feto é considerado protegido, e a terceira dose deverá ser aplicada durante o puerpério, para completar a imunização da mulher. Se não houver tempo suficiente para fazer as duas doses, o intervalo poderá ser diminuído para um mínimo de quatro semanas e a terceira dose deverá ser aplicada durante o puerpério.

Caso seja possível aplicar uma única dose, não se poderá esperar a proteção contra o tétano neonatal nesta gestação, mas a mulher deverá continuar o esquema adotado para protegê-la contra tétano acidental e ao feto em futuras gestações.

No Brasil, embora se observe uma tendência ao declínio da taxa de incidência do tétano neonatal a partir de 1983, ainda se faz necessário implementar e intensificar as ações de

\footnotetext{
${ }^{3}$ As situações $a$ e $b$ se aplicam também às mulheres em idade fértil, sendo preconizado o reforço a cada dez anos, caso não estejam grávidas; se não estiverem grávidas, aplica-se a situação $d$ (DPT - vacina tríplice, $\mathrm{dT}$ vacina dupla adulto, TT - toxóide tetânico).
} 
controle preconizadas pela Organização Mundial de Saúde (OMS), pois essas taxas ainda são preocupantes, em razão da alta letalidade da doença, que se situa entre $50 \%$ a $80 \%$ (BRASIL, 1998b).

Supõe-se, também, que a subnotificação de casos, tanto por parte dos profissionais ligados formalmente ao sistema de saúde, como por parte de parteiras leigas e curiosas, e a subnotificação de óbitos, ocultados em cemitérios clandestinos estejam mascarando a real magnitude do problema (BRASIL, 1998b).

Considera-se que os fatores de risco para a doença estão associados a aspectos econômicos, sociais e culturais, às características dos serviços de saúde, acessíveis ou não aos indivíduos e que, de alguma forma, condicionaram o risco de doença, incapacidade e morte, assim como suas possibilidades de recuperação. Esses elementos devem ser levados em consideração ao se propor e adotar medidas de controle e prevenção como estratégias de Saúde Pública.

No estudo realizado por mim em 1998, analisando 70 casos de tétano neonatal em Minas Gerais de 1989 a 1996, por meio das fichas de investigação e dos atestados de óbitos, pude observar que $64,3 \%$ dos casos ocorreram em municípios das regiões norte, nordeste e do Vale do Jequitinhonha (FIG. 3), pertencentes às Diretorias Regionais de Saúde de Montes Claros, Governador Valadares, Diamantina e Teófilo Otôni, correspondendo a áreas em que há maior carência de recursos e maior dificuldade de acesso aos serviços de saúde. Do total de casos confirmados de tétano neonatal, verifiquei, nas fichas de investigação, que 59,4\% eram de origem rural, $72,1 \%$ filhos de mães multíparas e $68,6 \%$ utilizaram substâncias inapropriadas no coto umbilical, destacando-se o azeite e o fumo, isolado ou não. A maioria $(65,3 \%)$ dos partos ocorreu no domicílio; $75,4 \%$ das mães informaram que não fizeram prénatal; 80,5\% não receberam a imunização antitetânica; e 60,8 \% foram assistidas por pessoa sem qualificação profissional. Observei uma associação significativa entre a origem do caso e 
a sua evolução. As crianças com tétano neonatal da zona rural tiveram 3,9 vezes mais chance de morrer do que as da zona urbana (VIEIRA, 1998).

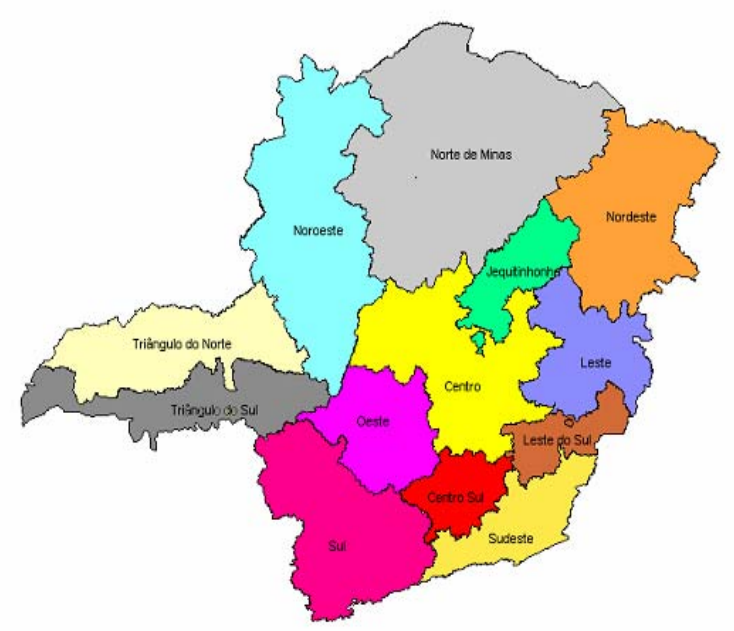

FIGURA 3 - Divisão territorial, segundo regiões administrativas do Estado de Minas Gerais - 2004.

Será que a eficácia, a disponibilidade e a funcionalidade da vacina não são suficientes para que as gestantes tomem a decisão de utilizá-la? O que faz as gestantes deixar de receber a vacina contra o tétano? Será que o pré-natal não é significante para que as gestantes tomem a decisão de freqüentá-lo? O que faz as gestantes deixar de freqüentar o prénatal? Será que existe algo que influencie na decisão da gestante de proteger-se do tétano? Como as representações sobre a doença e os limites de risco aos quais os indivíduos se colocam influenciam nessas decisões? Que risco é esse? Como ele é representado? Em que imaginário sociocultural ele está fundamentado? Em qual experiência social ele se inscreve?

A proposta de trabalho sobre o adoecer pelo tétano neonatal fundamenta-se na idéia de que as representações sociais são, pois, construídas nas interações entre as pessoas e de que cada pessoa as apreende na sua subjetividade. 
O termo "representação" possui várias conotações, sendo uma delas o "ato ou efeito de representar (se) [...] Reprodução daquilo que se pensa [...]” (FERREIRA, 1999, p.1747).

De acordo com Tavares e Teixeira (1998), o termo é polissêmico e utilizado como teoria e método em algumas correntes do pensamento, por exemplo, no materialismohistórico, na fenomenologia, na psicologia social e, mais recentemente na etnometodologia. Assim, buscaremos os fundamentos teórico-metodológicos nos autores que trabalham sobre as representações sociais, como forma de reflexão e análise sobre determinado objeto.

Para Durkheim (apud TAVARES; TEIXEIRA, 1988, p. 52), o conceito de representação coletiva significa "a especificidade e a primazia do pensamento social em relação ao pensamento individual”, quer dizer, as experiências humanas acontecem em sociedade e não se podem comparar as experiências vividas em coletividade com aquelas vividas individualmente.

Segundo Minayo (1994), "representações sociais" é uma expressão filosófica que significa a reprodução de uma percepção anterior ou do conteúdo do pensamento. Nas Ciências Sociais são definidas como categorias do pensamento, de ação e de sentimento que expressam a realidade, explicam-na, justificando-a ou questionando-a.

Neste estudo, utilizo o conceito de representações sociais apresentado por Minayo (1994, p.173) como "senso comum, idéias, imagens, concepções e visão de mundo que os atores sociais possuem sobre a realidade". Elas constituem material importante para a pesquisa social, pois se manifestam em condutas, hábitos e saberes.

Minayo (1994), com base na teoria de Gramsci, observa que as representações sociais podem ser mais bem compreendidas mediante o estudo com o senso comum e o bom senso, chamando a atenção para a solidez das crenças, em especial a religião, pelo seu potencial de produção de normas de conduta e conformismo. 
O senso comum não é uma concepção única, idêntica no tempo e no espaço; é o 'folclore' da filosofia e, como folclore, apresenta-se em inumeráveis formas; seu traço fundamental e mais característico é o de ser uma concepção desagregada, incoerente, inconseqüente, adequada à posição social e cultural das multidões, das quais ele é a filosofia (GRAMSCI, 1989, p.143).

Gramsci (1989) chama a atenção para a existência de uma multiplicidade de filosofias que estão em conflito e que não podem ser concebidas simplesmente como sistemas formais de pensamento, pelo contrário, ele iguala filosofia com concepção de mundo, uma vez que para ele "todos os homens são filósofos". De fato, ainda que de maneira inconsciente, em qualquer atividade intelectual que desenvolvemos está contida uma determinada concepção de mundo; é o que ele chama de "filosofia espontânea". Para ele, ser filósofo é ter uma concepção de mundo criticamente coerente.

Sendo assim, o pensamento de uma coletividade é o conjunto ou um estoque de representações presentes numa dada formação sociocultural, num dado momento histórico, das quais as pessoas que vivem nessa sociedade e nessa cultura lançam mão para se comunicar.

Dessa forma, é a mãe que tem uma forma própria de perceber a saúde e a doença, e essa percepção lhe permite fazer o que ela acredita ser certo.

Por outro lado, comumente se admite que o profissional de saúde tenha um conhecimento maior, "mais desenvolvido", do que o senso comum das mães, ou seja, o profissional de saúde teria o que Gramsci chama de "bom senso" entendido como um conhecimento mais elaborado e, às vezes, de maior valor, mas ao mesmo tempo, esse bom senso é originário do senso comum, como forma primária de conhecimento, segundo Gramsci (1984, p. 33), “a parte sadia do senso comum [...]; concepção de mundo, com ética adequada à sua estrutura". 
Para compreender as questões relacionadas ao adoecer pelo tétano neonatal, além dos fatores objetivos relacionados à doença e já estudados por Leroy e Garenne (1991), Melgaard et al (1988), Meneghel et al (1988), Tavares (1985), Veronesi et al (1991), dentre outros, faz-se necessário refletir sobre questões socioculturais que se incluem no comportamento das gestantes para proteger ou não o recém-nascido do risco de adoecimento.

Concordando que as representações são construções sociais intermediadas pela linguagem, busco compreender o risco de adoecer pelo tétano neonatal analisando o discurso das pessoas que viveram a experiência do adoecimento, o que me remete a uma abordagem qualitativa de análise.

Consideramos nessa abordagem que as características físicas e sociais do meio fixam nos indivíduos atributos que são desvelados à luz dos significados que o sujeito estabelece, explicitando o comportamento humano no contexto ao qual ele está inserido, evitando falsas interpretações ou generalizações equivocadas (TRIVIÑOS, 1987).

Nesse sentido Bogdan e Biklen, citados por Ludke e André (1986, p.13), destacam com muita propriedade algumas características básicas que configuram esse tipo de estudo:

1. 'A pesquisa qualitativa tem o ambiente natural como sua fonte direta de dados e o pesquisador como seu principal instrumento'. Supõe-se, neste caso, o contato direto do pesquisador com o contexto investigado.

2. 'Os dados coletados são predominantemente descritivos'. Além das transcrições de entrevistas e depoimentos, citações são freqüentemente usadas para subsidiar uma afirmação ou esclarecer um ponto de vista; todos os dados da realidade são importantes, e o investigador deve atentar-se para o maior número de informações presentes na situação investigada.

3. 'O significado que as pessoas dão às coisas e a sua vida são focos de atenção especial pelo pesquisador'. Nesses estudos, há sempre uma tentativa de captar a maneira como os sujeitos encaram as questões que estão sendo focalizadas.

4. 'A análise dos dados tende a seguir um processo indutivo'. Os pesquisadores não se preocupam com evidências que comprovem hipóteses definidas a priori. 
Considerando essas características, utilizei neste estudo a pesquisa qualitativa, para a compreensão do processo de adoecimento pelo tétano neonatal. 


\section{Capítulo 2}

\section{QUADRO DE ANÁLISE}

O objeto deste estudo pode ter mais visibilidade por meio de uma avaliação das políticas do Programa de Assistência Integral a Saúde da Mulher, com enfoque na atenção pré-natal, e no Programa Nacional de Imunização, com ênfase na vacinação antitetânica. Creio que pode ser importante também para a melhor compreensão do estudo uma visão do Programa de Saúde da Família como estratégia de Atenção Primária de Saúde.

\subsection{ASSISTÊNCIA PRÉ-NATAL NO CONTEXTO DA SAÚDE DA MULHER}

O Programa de Assistência Materno-Infantil, lançado por volta de 1974 pelo Ministério da Saúde, teve como ênfase os programas de prevenção à gravidez de alto risco e de suplementação alimentar às gestantes e às puérperas de baixa renda, por intermédio do Programa Nacional de Alimentação e Nutrição - PRONAN (BRASIL, 1974).

Entre 1974 e 1982, as políticas públicas de atenção à saúde da mulher encontravam-se associadas à atenção à sua prole, por intermédio do Programa MaternoInfantil, restringindo-se ao período de gestação, com o intuito de garantir a saúde das mães e de seus filhos. Nesse período, portanto, o enfoque central dos vários programas de saúde materno-infantil procurava intervir sobre os corpos das mulheres-mães, de maneira a 
assegurar que os corpos dos filhos fossem adequados às necessidades da reprodução social (OSIS, 1998).

Assim, até a década de 1980 a saúde pública brasileira, no que diz respeito à saúde da mulher, enfatizava os aspectos da maternidade. O debate predominante na sociedade se dava entre aqueles que defendiam o controle da natalidade tradicional, de um lado, e os simpatizantes das concepções neomalthusianas, de outro. A partir dessa década e contribuindo para o processo de democratização do País, o movimento de mulheres passou a intervir nas discussões sobre planejamento familiar, criticando a ausência de responsabilidade do governo brasileiro quanto à contracepção e aos abusos cometidos por instituições privadas como a Sociedade Civil de Bem-Estar Social (BENFAN) e outras que atuavam nessa área sem nenhum tipo de fiscalização. Outros setores da sociedade que também participavam desse debate eram os dos profissionais de saúde, integrantes do movimento de sanitaristas, demógrafos, cientistas sociais e militantes de partidos políticos.

Em 1983, o Ministério da Saúde estabeleceu base de ação programática para a Assistência Integral à Saúde da Mulher, com o objetivo de incluir a assistência da mulher desde a adolescência até a terceira idade, visando à incorporação da própria mulher como sujeito ativo no cuidado à saúde.

A existência do Programa de Assistência à Saúde Integral da Mulher (PAISM) deve-se, em parte, à participação dos movimentos de mulheres que sustentavam o princípio de que as decisões na esfera reprodutiva devem ser orientadas pelo livre-arbítrio dos indivíduos, em especial das mulheres, já que a reprodução biológica se viabiliza no corpo feminino. E ao Estado caberia assumir o seu papel de criar uma política ampla de saúde reprodutiva. 
O programa contempla, em suas linhas de ação e estratégias, um modelo assistencial em cujo contexto a integralidade e a eqüidade se incluem, e no qual se aborda a saúde da mulher de maneira global em todas as etapas da vida.

O PAISM tem como objetivo geral reduzir a morbimortalidade da mulher, garantindo à população feminina, de acordo com suas necessidades, o acesso aos serviços de saúde de diferentes complexidades, a partir da unidade sanitária local. Como parte de seus objetivos específicos, constam "a ampliação da cobertura e melhoria da qualidade das ações de pré-natal, parto e puerpério" e a "realização de ações de educação participativa em todas as atividades desenvolvidas". Esse programa especificou um conjunto de atividades básicas e simplificadas de prevenção, diagnóstico e terapêutica, referente ao pré-natal, atendimento ao parto, acompanhamento pós-parto, à ginecologia preventiva e patológica, à regulação da fertilidade e tratamento da esterilidade, ao controle do câncer ginecológico e de mama e das doenças sexualmente transmissíveis (BRASIL, 1984).

Em 1987, a Conferência Internacional sobre Maternidade Segura, realizada em Nairobi, no Quênia, colocou pela primeira vez em nível internacional a discussão sobre o problema da morte de mulheres por complicações ligadas à gestação, ao parto e ao puerpério. Para o UNICEF, o segundo momento importante em que se discutiu essa questão foi em 1990, por ocasião da Conferência da Infância. Nessa reunião, os países presentes - inclusive o Brasil - foram signatários da Declaração e Plano de Ação para a redução em $50 \%$ de suas taxas de mortalidade materna. ${ }^{4}$ Essa meta foi reenfatizada em 1994, na Conferência Internacional sobre População e Desenvolvimento ocorrida no Cairo, e em 1995, na $4^{a}$ Conferência Mundial sobre a Mulher, em Beijing, China (UNICEF, 1997).

\footnotetext{
${ }^{4}$ É a taxa ou coeficiente que mede as mortes maternas, ou seja, aquelas ocorridas durante a gestação ou dentro de um período de 42 dias após o término da gestação independentemente de duração ou localização da gravidez, devida a qualquer causa relacionada com ou agravada pela gravidez (WHO, 1992).
} 
A assistência pré-natal é definida pelo Programa de Assistência Integral de Saúde da Mulher como "os cuidados de saúde dispensados à mulher visando assegurar a higidez de seu organismo, e o crescimento e desenvolvimento adequados de seu concepto, reduzindo assim a morbimortalidade materna e perinatal". Ela deve ser organizada para atender às reais necessidades da população de gestantes, por meio de ações de saúde que devem estar voltadas para a cobertura de toda a população - alvo da área de abrangência da unidade de saúde, assegurando continuidade no atendimento, acompanhamento e avaliação dessas ações sobre a saúde materno-perinatal (BRASIL, 1997a).

O Ministério da Saúde recomenda o início da assistência pré-natal até o quarto mês da gestação e um número mínimo de seis consultas de acompanhamento, sendo, preferencialmente, uma no primeiro trimestre, duas no segundo e três no terceiro trimestre da gestação, e uma consulta no puerpério, até 42 dias depois do nascimento (BRASIL, 2000).

O principal objetivo da assistência pré-natal é acolher a mulher desde o início da gravidez. A adesão das mulheres ao pré-natal está relacionada com a qualidade da assistência prestada pelo serviço e pelos profissionais de saúde, o que será essencial para a redução dos elevados índices de mortalidade materno-perinatal verificados no Brasil. No que se relaciona especificamente ao acompanhamento da gestante, deve-se ter como objetivos:

- captar gestantes não inscritas no pré-natal;

- reconduzir faltosas ao pré-natal, especialmente as de alto risco;

- acompanhar a evolução em alguns aspectos da gestação;

- completar trabalho educativo com a gestante e seu grupo familiar;

- reavaliar, dar seguimento ou reorientar as pessoas visitadas sobre outras ações desenvolvidas pela Unidade de Saúde. 
Formiga (1999, p.155) afirma:

O PAISM tem na sua formulação teórica o marco de sua força, representando um modelo de política pública de saúde que, adequadamente estabelecido, segundo o processo de descentralização do Sistema Único de Saúde (SUS), tem, na área federal, a responsabilidade técnico-normativa que, desenvolvendo estratégias conjuntas, resultaria na melhoria da execução da assistência, sob a égide das secretarias estaduais e municipais de saúde.

A avaliação mais recente apresentada pelo Ministério da Saúde data de 1990 e se encontra no Relatório de Atividades 1990 da Divisão Nacional de Saúde Materno-Infantil. Em supervisão feita em 16 Estados com um total de 147 unidades de saúde visitadas para avaliar o grau de implantação das ações de assistência nos programas em relação ao pré-natal, observou-se que $64 \%$ estavam implantadas, $16 \%$ parcialmente implantadas e $20 \%$ não implantadas. Percebeu-se ainda que, de um modo geral, houve um avanço na qualidade da assistência prestada nos serviços da rede básica. Entretanto, não foi satisfatório o resultado pesquisado no item captação precoce de gestantes e busca das que não compareceram ao prénatal (BRASIL, 1990).

Em 1992, baseando-se nesse mesmo levantamento do MS, a Comissão de Cidadania e Reprodução, em sua primeira atividade de impacto, faz uma avaliação do estado de implementação do PAISM em âmbito nacional. Verificou-se que não se apresentava, então, qualquer impacto de melhoria nesse período. "No que diz respeito aos aspectos reprodutivos, não houve qualquer melhora: os coeficientes de mortalidade materna seguem elevados aproximando o Brasil aos países mais atrasados do mundo" (COSTA, 1992).

A Coordenação de Saúde da Mulher do Ministério da Saúde informou que não existem dados atualizados relativos à implantação do PAISM. Em 1996 foi solicitado às Secretarias Estaduais de Saúde que voltassem a aplicar o instrumento de avaliação, mas, em decorrência da insuficiência de dados, não foi possível consolidar os resultados obtidos. 
O cruzamento de dados sobre os registros de mortes maternas do DATASUS e o número de nascidos vivos do IBGE de 1980 a 2000 permite visualizá-los em uma série histórica (GRAF. 1), na qual se pôde observar que desde 1985 os coeficientes de morte materna no Brasil praticamente não vêm mostrando alteração, mantendo-se ao redor de 55 por mil nascidos vivos.

GRÁFICO 1 - Coeficiente de mortalidade materna por 100.000 nascidos vivos por triênio no Brasil, entre 1980 e 2000.

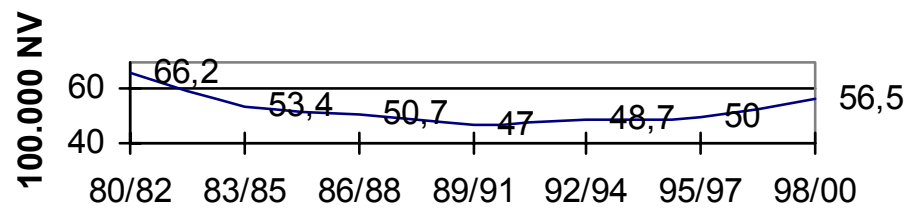

Anos

Fonte: DATABUS, IBGE.

A morte materna é a mais subnotificada, isso quer dizer, é a morte que é omitida com maior freqüência, em razão de ser decorrente de complicações na gestação, parto ou puerpério. O problema da subnotificação ocorre em quase todos os países do mundo, mas nos países em desenvolvimento essa situação é ainda pior, pois, além da subnotificação, ocorre também o sub-registro de óbitos.

No Brasil, não existem pesquisas para dimensionar a magnitude da mortalidade materna em cada Estado. Apenas alguns estudos locais têm sido utilizados para estimar os coeficientes de morte materna no País e por região, aplicando-se fatores de correção para diminuir o impacto da subnotificação desses óbitos maternos. $\mathrm{O}$ fator de correção da 
subnotificação da morte materna para o Brasil é de duas vezes, isto é, estima-se que para cada morte declarada como materna existe uma que não foi declarada (TANAKA; MITSUIKI, 1999).

Dessa forma, se os dados atuais indicam que no Brasil, em 1997, a taxa de mortalidade materna foi de 55,1 por 100 mil nascidos vivos, ela, na realidade deve estar, no ano referido, muito próxima de 110 por 100 mil nascidos vivos. Esse valor nos aproxima dos países mais pobres da América Latina.

Embora os dados indiquem tendência decrescente na taxa de mortalidade materna, as estimativas ainda são extremamente preocupantes, em comparação aos países desenvolvidos, onde elas estão abaixo de 10 óbitos por 100 mil nascidos vivos.

A assistência institucional ao parto no País teve como média, no período de 1992 a 1996, o percentual de 91,5\% estimando-se para 1997 um índice superior a 95\%, sendo para $95,9 \%$ na área urbana e 78,2\% na área rural. Portanto, $21,8 \%$ dos partos da área rural foram domiciliares. Ainda no mesmo período, a assistência médica ao parto foi de 87,5\% (FORMIGA, 1999).

No QUADRO 2, a seguir, observa-se que nesse mesmo período a percentagem de gestantes que tiveram pelo menos uma consulta de pré-natal foi de $84 \%$, apenas $51,1 \%$ tinham o cartão de gestante, mas somente $45,3 \%$ receberam as duas doses de vacinação antitetânica necessárias para proteger o recém-nascido (BRASIL, 1999b). 


\section{QUADRO 2}

Algumas características da assistência pré-natal dos nascidos vivos nos últimos cinco anos anteriores da PNDS/96.

\begin{tabular}{cr|lr|lr}
\hline \multicolumn{2}{c|}{\begin{tabular}{c} 
NÚMERO DE CONSULTAS \\
\multicolumn{2}{c|}{ DE PRÉ-NATAL }
\end{tabular}} & \multicolumn{2}{c|}{$\begin{array}{c}\text { PERÍODO DE GESTAÇÃO } \\
\text { PRIMEIRA CONSULTA } \\
\end{array}$} & & \multicolumn{2}{c}{$\begin{array}{r}\text { VACINAÇÃO } \\
\text { ANTTETANICA }\end{array}$} \\
\hline Nenhuma & 14,3 & Sem pré-natal & 14,3 & Nenhuma & 36,5 \\
$1-3$ consultas & 8,1 & $0-3$ meses & 66,0 & 1 dose & 13,2 \\
$4-6$ consultas & 28,4 & $4-6$ meses & 17,8 & 2 doses & 45,3 \\
7 consultas & 47,5 & $7-9$ meses & 1,5 & Sem resposta & 5,0 \\
Sem resposta & 1,7 & Sem resposta & 0,4 & Com cartão de Pré-natal 51,1 \\
\hline
\end{tabular}

Fonte: MINISTÉRIO DA SAÚDE. Fiocruz. Radis/Tema: 17, fev.1999.

Uma das maneiras de avaliar a qualidade do controle pré-natal é o grau de cobertura da vacinação antitetânica e o uso e posse do cartão da gestante devidamente preenchido. Observa-se no quadro anterior que mais de um terço das gestantes não recebeu nenhuma dose da vacina antitetânica. Quanto ao cartão, 48,9\% das gestantes não o possuíam. Segundo a Pesquisa Nacional de Demografia e Saúde (PNDS 1996) esses percentuais são mais elevados na zona rural e entre as gestantes do Norte e Nordeste (BENFAN, 1997).

Valores semelhantes a esses indicadores da rede pública devem ser encontrados em relação às gestantes atendidas por serviços privados, quer sejam pagos diretamente pela cliente ou mediante convênios via empresas e planos de saúde.

A mortalidade infantil de 48 por 1.000 nascidos vivos, segundo a PNDS 1996, pode ter variações importantes, em que pese à carência de qualidade na assistência pré-natal e institucional ao parto. Para crianças cujas mães não tiveram atendimento pré-natal e no parto, a taxa alcança 207 por 1.000 nascidos vivos, sofrendo redução para 63 por 1.000 nascidos vivos, quando da atenção pré-natal ou parto, e ainda para 20 por 1.000 nascidos vivos, se a gestação é seguida de pré-natal e parto institucional (BENFAN, 1997). 
É evidente que a resolução desses problemas de saúde depende da freqüência e da qualidade da assistência ao parto. Em estudo realizado por Tanaka e Mitsuiki (1999) em 15 cidades brasileiras, as autoras verificaram que entre os óbitos por causas obstétricas diretas, $64,3 \%$ das mulheres haviam feito o exame pré-natal, $7,1 \%$ não o realizaram e em $28,6 \%$ a situação era ignorada. Entre os óbitos por causas obstétricas indiretas, 57,1\% realizaram o exame e 14,3\% não o fizeram. Das mulheres que faleceram após 42 dias do parto (morte materna tardia), nenhuma havia realizado o exame pré-natal. Portanto, a qualidade da assistência ao pré-natal e ao parto depende tanto da instituição de saúde como do profissional que presta o atendimento.

Considerando que para 1996 o universo de atenção à saúde era de 157.079.573 habitantes, sendo 79.632.032 mulheres, das quais 40.839.714 estavam em idade fértil, de acordo com o DATASUS foram realizados 2.933 .428 partos assistidos pelo sistema (BRASIL, 1997b). Podemos inferir que o número de partos domiciliares e partos sem assistência médica no Brasil, principalmente em áreas rurais, deve ser bastante significativo.

No sentido de solucionar esses problemas, o Ministério da Saúde instituiu em 2000 o Programa de Humanização no Pré-natal e Nascimento (PHPN) por intermédio das Portarias GM 569, 570, 571 e 572, cujo objetivo é assegurar acesso e a qualidade do acompanhamento pré-natal, da assistência ao parto e puerpério e da assistência neonatal. As ações essenciais do Programa são:

- garantir a primeira consulta do pré-natal até o $4^{\circ}$ mês de gestação;

- garantir os seguintes procedimentos:

1. realizar no mínimo seis consultas de acompanhamento pré-natal, sendo, preferencialmente, uma no primeiro trimestre, duas no segundo trimestre e três no terceiro trimestre de gestação; 
2. realizar uma consulta no puerpério, até 42 dias após o nascimento;

3. realizar exames laboratoriais que fazem parte do protocolo.

4. aplicar vacina antitetânica/dose imunizante (2 doses), segundo o esquema recomendado, ou dose de reforço em mulheres já imunizadas.

Para estimular a implantação do PHPN, o Ministério da Saúde estipulou o pagamento de incentivos aos municípios, de modo que as ações desenvolvidas deverão ser informadas mensalmente por intermédio do sistema de informação, o SISPRENATAL.

De acordo com Serruya et al (2004), embora se observe no País um incremento de $20 \%$ no acesso ao pré-natal, elevando a média de consultas por mulher que faz o parto no SUS de 3,4 em 1999 para 4,4 em 2002, não se pode afirmar que esse incremento seja devido ao PHPN. Mais importante que uma avaliação quantitativa é a avaliação qualitativa, para que se possa perceber se o Programa está incluindo justamente as mulheres em maior desvantagem social por causa do local de residência, região, escolaridade, raça/etnia ou renda.

Em Minas Gerais, dos 853 municípios, 718 já aderiram ao PHPN, com portaria publicada pelo Ministério da Saúde, representando 84\% do total de municípios do Estado. Até março de 2004, de 304.266 gestantes, já haviam sido cadastradas 195.677 gestantes, porém para apenas 12.101 delas tinha sido informada a conclusão da assistência. Esses dados indicam uma situação não desejável, com baixa cobertura e qualidade inadequada no prénatal, falta de informação do SISPRENATAL e perda considerável de recursos financeiros dos incentivos do Programa.

Em muitos lugares no Brasil o acesso a hospitais, médicos, profissionais e postos de saúde é dificultado pela distância, más condições de transporte e comunicação. A assistência ao parto domiciliar por parteiras tradicionais faz parte do cotidiano de 
comunidades extrativistas, rurais, ribeirinhas e indígenas do País. Segundo o Ministério da Saúde, existem cerca de 60 mil parteiras responsáveis por $15 \%$ dos nascimentos registrados anualmente, atuando no Brasil, das quais 40 mil nas Regiões Norte e Nordeste, o que representa cerca de 400 mil partos domiciliares (AS PARTEIRAS DA FLORESTA, 1998).

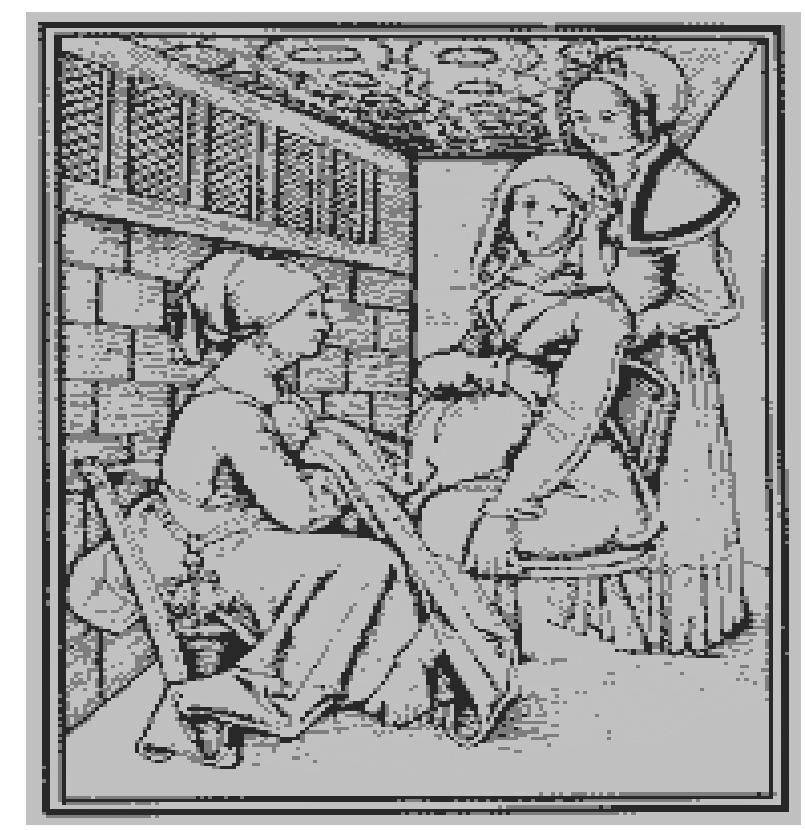

FIGURA 4 - Ilustração da obra de Rösslin, representando um parto de 1513.

Iniciativas pioneiras estão sendo desenvolvidas, de modo que os Estados do Amapá e de Pernambuco, ambos com o financiamento do Fundo de Apoio ao Trabalhador FAT, UNICEF e ONGs -, em 1995 e 1991, respectivamente, implementaram o Projeto Parteiras Tradicionais com o objetivo de resgatar, valorizar e legitimar o trabalho, ao mesmo tempo de possibilitar a ampliação de conhecimentos. As parteiras recebem a capacitação e treinamento, e entre os temas discutidos consta gravidez de alto risco, complicações na gravidez e no parto, encaminhamento da parturiente para o pré-natal realizando exames e vacinação de rotina, higiene do bebê, tétano neonatal, amamentação e vacinação infantil. Recebem também um kit contendo panela de pressão, tesoura, escovinha para limpar as 
unhas, saboneteira, lanterna, toalha, balança, linha zero e plástico para cobrir a área de parto. Todas as profissionais cadastradas possuem, ainda, crachás, que lhes dão acesso aos hospitais públicos e permitem que acompanhem os partos de suas pacientes. Muitas já estão recebendo salário ou o pagamento previsto pelo SUS para o parto domiciliar repassado pelas Secretarias Municipais de Saúde. As parteiras cadastradas preenchem uma ficha do Ministério da Saúde, na qual descrevem a realização de cada parto. Essas fichas contribuem para o acompanhamento e aferição dos índices de morbimortalidade materna e infantil, os quais têm apresentado queda expressiva nesses dois estados (CARVALHO et al, 1998; POLIS, 2002).

O Projeto Parteiras Tradicionais do Amapá foi uma das 20 experiências premiadas no Ciclo de Premiação de 1998 do Programa de Gestão Pública e Cidadania, iniciativa conjunta da Fundação Getúlio Vargas, da Fundação FORD e do BNDES, de modo que iniciativas como estas deveriam ser implementadas em outros Estados brasileiros.

Em 2000, depois de 11 anos de experiência com capacitação de parteiras, a ONG Grupo Curumim - Gestação e Parto elaborou um guia: o Livro da Parteira, e reeditou seu manual, Trabalhando com Parteiras Tradicionais, revisados, com a participação de vários profissionais e organizações, e publicados pelo Ministério da Saúde. O propósito dessas publicações é contribuir com uma proposta de conteúdo unificado para a capacitação de parteiras tradicionais e, ao mesmo tempo, para que Estados e Municípios possam estruturar equipes de instrutores. Outro objetivo é divulgar estratégias para a educação continuada, com uma metodologia lúdica, vivencial, que se tem mostrado eficaz na atividade de capacitação de parteiras tradicionais (JUCÁ; MOULIN, 2002).

A integração entre as parteiras tradicionais e os serviços de saúde pode trazer benefícios valiosos para a saúde pública e abrir caminho para um número de atividades relacionadas com a promoção da saúde, contribuindo, conseqüentemente, para um declínio 
gradual da morbimortalidade materna e infantil, inclusive para a eliminação do tétano neonatal.

No Brasil, o parto domiciliar ainda é uma realidade, pois, segundo a Pesquisa Nacional de Demografia e Saúde (PNDS), realizada em 1996, existe uma incidência de 20\% de partos domiciliares nas áreas rurais, onde são maiores as dificuldades de acesso aos serviços de saúde. Esses partos, na sua maioria, foram atendidos por parteiras tradicionais. A referida pesquisa indicou que, no meio rural:

- das gestantes, $32 \%$ não tiveram nenhum atendimento pré-natal;

- o acesso ao parto hospitalar foi menor, sobretudo entre as mulheres com nenhum estudo ou poucos anos de estudo e entre aquelas que não tiveram assistência prénatal;

- a taxa de mortalidade infantil entre os filhos das mulheres de áreas urbanas que não tiveram nenhuma assistência pré-natal e no parto foi de 42 por 1.000 nascidos vivos e nas mulheres de áreas rurais chega a 65 por 1.000 nascidos vivos;

- o Norte e o Nordeste apresentam indicadores que revelam maior carência de serviços de saúde.

Considerando a diversidade socioeconômica, cultural e geográfica do País, é fundamental a articulação do trabalho da parteira tradicional ao sistema de saúde, com vista a melhorar a assistência ao parto domiciliar e reduzir a morbimortalidade materna e perinatal. Portanto, são responsabilidades do Sistema Único de Saúde:

- fazer o levantamento situacional da assistência ao parto domiciliar, incluindo um levantamento das dificuldades enfrentadas pelas parteiras; 
- realizar o cadastramento das parteiras e o seu recadastramento a cada cinco anos;

- articular o trabalho das parteiras com o Programa Saúde da Família (PSF) e o Programa de Agentes Comunitários de Saúde (PACS), sistematizando um acompanhamento e avaliação permanente desse trabalho;

- promover a sensibilização e a capacitação de profissionais de saúde para que atuem com as parteiras;

- realizar capacitações e manter um processo de educação permanente para as parteiras;

- melhorar o registro de informações referentes ao parto domiciliar, para alimentação do SINASC e do SIM;

- elaborar e distribuir materiais educativos;

- propiciar apoio logístico para as gestações e partos com risco obstétrico.

Foi considerando essa realidade e as responsabilidades acima, que em março de 2000 foi iniciado o Programa Trabalhando com Parteiras Tradicionais, a partir de uma parceria entre a Área Técnica de Saúde da Mulher do Ministério da Saúde e a ONG feminista Grupo Curumim. Nesse trabalho, envolveram-se e agregaram-se secretarias estaduais e municipais de saúde, a Fundação Nacional de Saúde (FUNASA) e outras instituições e organizações sociais. O objetivo do Programa consiste em sensibilizar gestores estaduais e municipais e profissionais de saúde a desenvolver ações para melhorar a assistência ao parto domiciliar.

Em Minas Gerais a primeira experiência organizada de treinamento com parteiras ocorreu em Montes Claros, em 1989, por iniciativa de docentes do Departamento de 
Enfermagem Materno-Infantil e Saúde Pública da Escola de Enfermagem da UFMG, no qual foram treinadas cerca de 60 parteiras leigas do norte do Estado. Essa experiência já apontava a recomendação de que os serviços de saúde se empenhassem no Programa de Assistência à Mulher e à Criança e que aproveitassem esse elemento da comunidade - a parteira - trazendoa para os Centros e Postos de Saúde, treinando-a no sentido de melhorar o sistema de referência e contra-referência, com o propósito de diminuir os riscos de morbimortalidade materna e neonatal (MENDES; CAVALCANTI, 1989).

No Estado de Minas, atualmente, 5\% dos partos não ocorrem em instituições, sendo, portanto, domiciliares, totalizando cerca de 15 mil por ano. O Programa "Trabalhando com Parteiras Tradicionais" teve início, no Estado, em 2001. Depois da verificação de maior concentração de parteiras nas Diretorias Regionais de Diamantina, Montes Claros, Teófilo Otôni e Pedra Azul, realizou-se, em parceria com o Ministério da Saúde e a Diretoria Regional de Saúde de Diamantina, em novembro de 2001, uma capacitação de multiplicadores para profissionais de saúde dessas regiões. Na ocasião foram treinados 33 médicos e enfermeiros do "Programa de Saúde da Família", como multiplicadores da capacitação das parteiras, o mais próximo possível do local de residência delas.

A primeira capacitação de parteiras do Programa ocorreu em maio de 2002, no município de Chapada do Norte - região de Diamantina -, quando também participaram do treinamento médicos e enfermeiros do PSF, para apoiá-las e acompanhar o trabalho delas, oferecendo-lhes a retaguarda necessária para os casos encaminhados. De lá para cá, já foram treinadas 207 parteiras e estima-se que ainda haja cerca de 100 para treinar. O último treinamento ocorreu no período de 27/9 a 1\%/10/04, em Teófilo Otôni. Foram treinadas 12 parteiras e já está sendo programado um treinamento para parteiras de reservas indígenas do Estado. Além do treinamento específico, as parteiras recebem um kit contendo material 
adequado para a assistência ao parto domiciliar, com garantia de reposição e esterilização dos materiais pelas secretarias municipais de saúde.

Segundo avaliação da Dra. Márcia Rovena de Oliveira, Referência Técnica de Saúde da Mulher da Secretaria de Estado da Saúde de Minas Gerais, o trabalho tem dado visibilidade aos partos domiciliares no Estado, possibilitando a aproximação das parteiras ao sistema institucional de saúde, e pode ser uma importante estratégia para melhorar os indicadores de saúde observados em regiões com baixos Índices de Desenvolvimento Humano (IDH) $)^{5}$ e altas taxas de morbimortalidade materna e neonatal.

\subsection{O PROGRAMA NACIONAL DE IMUNIZAÇÃO E SUA CONTRIBUIÇÃO NA PREVENÇÃO DO TÉTANO NEONATAL}

O Programa Nacional de Imunizações (PNI) foi formulado em 1973, por determinação do então ministro da Saúde, Mário Machado Lemos, como parte de conjunto de medidas que se destinavam a redirecionar a atuação governamental no setor. Até então, as ações de imunização no país, se caracterizavam pela descontinuidade, pelo caráter episódico e pela reduzida área de cobertura. Essas ações eram conduzidas por programas especiais, a exemplo das que se destinavam à erradicação da varíola e ao controle da tuberculose (BRASIL, 1989).

As atividades vinham sendo desenvolvidas por iniciativa de governos estaduais, carecendo, pois, de normatização e de coordenação central que lhes proporcionasse

\footnotetext{
${ }^{5}$ Criado em 1990 por iniciativa da Organização das Nações Unidas, o IDH reflete as condições de três variáveis básicas para uma qualidade de vida digna: a expectativa de vida ao nascer, a escolaridade e o produto interno bruto per capta. Disponível em: www.idhnaweb.rg3.net
} 
homogeneidade das condutas no desenvolvimento das atividades durante a sua operacionalização.

A proposta básica para o programa, constante de documento elaborado por técnicos do Departamento Nacional de Profilaxia e Controle de Doenças (Ministério da Saúde) e da Central de Medicamentos (CEME), foi aprovada em reunião realizada em Brasília, no dia 18 de setembro de 1973, presidida pelo próprio ministro e que contou com a participação de renomados sanitaristas e infectologistas, bem como de representantes de diversas instituições.

O PNI foi institucionalizado em 1975, na gestão do ministro Paulo de Almeida Machado, tendo como principal objetivo controlar e erradicar doenças como a poliomielite, o sarampo, a difteria, o tétano, a coqueluche, a febre amarela, a hepatite $\mathrm{B}$, a rubéola congênita e as formas graves de tuberculose, mediante a imunização sistemática da população (BRASIL, 1989).

A institucionalização do PNI foi resultante da soma de fatores, de âmbito nacional e internacional, que convergiam para estimular e expandir a utilização de agentes imunizantes no País, destacando-se os seguintes:

- O término da Campanha de Erradicação da Varíola no Brasil, em 1973, após haver sido certificado o desaparecimento da doença, por comissão de peritos enviada pela Organização Mundial de Saúde (OMS). A Campanha de Erradicação da Varíola legou à saúde pública brasileira notável experiência prática no campo da imunização e da vigilância epidemiológica, além de uma estrutura técnico-operacional vinculada a órgãos federais e estaduais. Essa estrutura já vinha sendo mobilizada, desde 1971, para a implementação de programas, como o Plano Nacional de Controle da Poliomielite, e a realização de algumas 
experiências locais com a aplicação simultânea de vacinas, incluindo-se a recém-introduzida vacina contra o sarampo.

- A atuação da Central de Medicamentos (CEME), criada em 1971 e que se voltava para a organização de um sistema de produção nacional e de suprimento de medicamentos essenciais à rede de serviços públicos de saúde. Tal sistema incluía os produtos imunobiológicos, o que demandava a necessidade de definição de um programa de imunizações logisticamente integrado e abrangendo todo o País.

- As recomendações do Plano Decenal de Saúde para as Américas, aprovado na III Reunião de Ministros da Saúde, realizada no Chile em setembro de 1972, que enfatizaram a necessidade da coordenação de esforços para controlar, no continente, as doenças evitáveis por imunização.

Essas circunstâncias fizeram com que o Ministério da Saúde, ao instituir o PNI, buscasse a integralidade das ações de imunização realizadas no País, que eram, então, fortemente marcadas pela atuação de programas nacionais de controle de doenças específicas. O PNI passou a coordenar, assim, as atividades de imunização desenvolvidas rotineiramente na rede de serviços e, para tanto, traçou diretrizes pautadas na experiência da Fundação Serviços de Saúde Pública (FSESP), com a prestação de serviços integrais de saúde por intermédio de sua rede própria.

A legislação específica sobre imunizações e vigilância epidemiológica (Lei n. 6.259 de 30/10/1975 e Decreto n. 78.231 de 30/12/71976) deu ênfase às atividades permanentes de vacinação e contribuiu para fortalecer institucionalmente o programa.

Depois de sua formulação, em 1973, e institucionalização, em 1975, coordenadas pela Divisão Nacional de Epidemiologia e Estatística de Saúde, do Departamento Nacional de 
Profilaxia e Controle de Doenças do Ministério da Saúde, o PNI teve o seguinte histórico institucional (BRASIL, 1998a):

- 1974 a 1979 - coordenado pela Fundação Serviços de Saúde Pública (FSESP), por delegação do Ministério da Saúde;

- 1980 a 1990 - responsabilidade da Divisão Nacional de Epidemiologia da Secretaria Nacional de Ações Básicas de Saúde (SNABS), do Ministério da Saúde;

- 1990 - transferido para a Fundação Nacional de Saúde (FNS), e localizado na Coordenação de Imunizações e Auto-Suficiência em Imunobiológicos do Departamento de Operações;

- 1994 - transferido do Departamento de Operações para o Centro Nacional de Epidemiologia (CENEPI), da Fundação Nacional de Saúde.

O desenvolvimento do programa é orientado por normas técnicas estabelecidas com a participação das secretarias estaduais e municipais de saúde, contando, também, na sua operacionalização, com outras instituições, de modo a assegurar a aceitação e uniformidade de uso em todo o território nacional.

O PNI tem como objetivos prioritários:

- contribuir para a manutenção do estado de erradicação da poliomielite;

- contribuir para o controle ou erradicação do sarampo, da difteria, do tétano neonatal e acidental, da coqueluche, das formas graves de tuberculose, da rubéola - em particular a congênita - da caxumba, da hepatite B e da febre amarela;

- contribuir para o controle de outros agravos, coordenando o suprimento e a administração de imunobiológicos indicados para situações ou grupos populacionais específicos. 
A meta operacional básica do programa é a vacinação de $100 \%$ das crianças menores de um ano, com todas as vacinas indicadas no esquema básico. Nesses 30 anos, o PNI tem preconizado como estratégia básica para o alcance dessa meta a vacinação rotineira na rede de serviços de saúde. Ocorre que, embora tenha havido grandes investimentos na estruturação e expansão dessa rede, a sua deficiente cobertura tem sido apontada como fator determinante dos baixos índices de vacinação.

A vacinação oferecida no dia-a-dia da prestação de serviços de saúde é a estratégia básica para o alcance da meta de imunizar 100\% das crianças que nascem a cada ano no País, tendo como grupo prioritário os menores de um ano para aplicação do esquema básico.

As coberturas vacinais nesse grupo, nos últimos 22 anos - 1975 a 1997 -, sofreram oscilações com leves tendências de incremento ao longo período, mas, quase sempre, mantiveram-se abaixo dos percentuais desejados, à exceção da BCG, cujos índices são crescentes e chegam a 100\% nos últimos três anos e da vacina contra o sarampo em 1997.

Cabe destacar o desafio representado pela intensificação ou incorporação à rotina dos serviços de saúde, nos últimos cinco anos, da vacina dupla adulto (dT), preconizada, inclusive, para todas as mulheres em idade fértil (FIG. 5), da tríplice viral, da vacina contra a hepatite B e contra a febre amarela nas áreas endêmicas. 


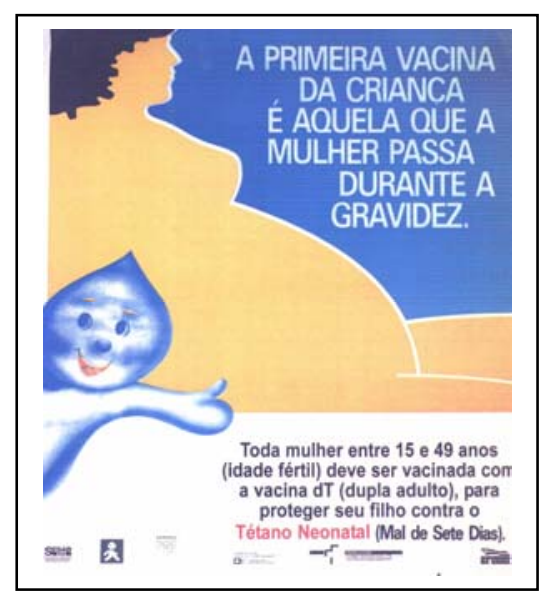

FIGURA 5 - Cartaz de divulgação da vacina dT para gestantes e mulheres em idade fértil. Fonte: MINISTÉRIO DA SAÚDE, Brasil.

Por esse motivo, ao longo do tempo têm sido adotadas diferentes estratégias, na tentativa de viabilizar, em curto prazo, o controle das doenças imunopreviníveis. Essas estratégias incluem:

• Dias Nacionais de Vacinação - Instituídos em 1980 e mantidos até o momento, constituem o exemplo mais positivo e de resultado mais significativo, considerando a ocorrência do último caso de poliomielite em 1989 e a obtenção, pelo Brasil, em 1994, do Certificado Internacional de Erradicação da Transmissão Autóctone do Poliovírus Selvagem. Os dias nacionais de vacinação vêm sendo realizados durante 24 anos consecutivos (19802004), em um só dia, duas vezes ao ano, visando à vacinação discriminada da população de zero a quatro anos completos.

• Multivacinação - Embora haja dificuldades inerentes à administração das vacinas injetáveis em campanhas extensivas e sistemáticas, como nos dias nacionais de vacinação contra a poliomielite, as iniciativas têm demonstrado, a despeito de opiniões contrárias e de experiências negativas, que a multivacinação, além de não comprometer as 
coberturas contra a poliomielite, tem permitido uma recuperação dos índices para as demais vacinas. Estados e Municípios continuam aproveitando os dias nacionais de vacinação para oferecer outras vacinas, inclusive para grupos diferenciados, o que tem contribuído de forma decisiva para possibilitar o acesso a outros imunobiológicos.

口 Vacinação contra o Sarampo - Com iniciativas implementadas a partir de 1986, em 1992 foi realizada a Campanha Nacional de Vacinação contra o Sarampo, entre 25 de abril e 22 de maio, quando foram vacinadas mais de 48 milhões de crianças de forma indiscriminada: $96 \%$ da população entre 9 meses e 14 anos de idade, sendo que $68 \%$ dos Municípios atingiram coberturas iguais ou maiores que 95\%. Porém, como nos anos seguintes somente $32 \%$ dos Municípios, em média, atingiam coberturas satisfatórias na vacinação de rotina $-95 \%$ dos menores de um ano -, os demais $(68 \%)$ vinham acumulando grupos de crianças suscetíveis à doença, de modo que em junho de 1997 a epidemia se expandiu rapidamente de São Paulo para as demais regiões.

Em vista disso foram realizadas campanhas indiscriminadas para o grupo de 6 meses a 5 anos, indicando-se a vacinação seletiva para a população de 5 a 14 anos nas escolas e para profissionais de saúde.

- Estratégias para outras vacinas - A vacinação com a tríplice viral - contra o sarampo, a caxumba e a rubéola, foi implementada, a partir de 1992, em São Paulo e, a seguir, em outras unidades federadas. A vacinação contra a febre amarela começou a ser implementada na rede de serviços de saúde, na região endêmica, a partir de 1991, e cuja responsabilidade direta passa em 1994 para o PNI, em articulação com o Programa de Controle da Febre Amarela e Dengue. Quanto à vacina contra a hepatite B, a partir de 1991, consolidou-se em grupos de risco, especialmente em profissionais de saúde, e da população menor de 15 anos na área endêmica, tendo sido ampliada, em 1997, para todo o País a 
vacinação de menores de um ano, com perspectiva de implementar essa oferta para os menores de 15 anos. A vacinação de idosos foi implementada a partir de 1999, Ano Internacional do Idoso, com a vacina contra o vírus Influenza. A campanha é feita, anualmente, com a oferta de outras vacinas preconizadas, como a dupla tipo adulto (dT).

As tendências do comportamento epidemiológico das doenças evitáveis pelas vacinas, objeto do PNI, são acompanhadas mediante notificação semanal de casos ao Centro Nacional de Epidemiologia (CENEPI). Esses dados são complementados por informes específicos, cujo detalhamento varia de acordo com o estágio de controle de cada doença.

As principais metas estabelecidas, e que também representam compromissos internacionais, são as seguintes:

$>$ manter a interrupção da circulação de poliovírus selvagens no país;

$>$ alcançar a eliminação do sarampo até o ano 2000;

$\rightarrow$ alcançar a eliminação do tétano neonatal até o ano 2003;

> implementar o controle do tétano acidental em todo o país;

> implementar o controle da rubéola congênita em todo o país;

$>$ implementar o controle da difteria em todo o país;

$\rightarrow$ pesquisar os sorotipos prevalentes de Bordetella pertussis para o controle da coqueluche;

> implementar o sistema de vigilância epidemiológica das hepatites virais e implementar a vacinação universal dos menores de um ano contra a hepatite B;

> implementar o sistema de vigilância epidemiológica das meningites. 
A seguir, para fins deste trabalho, destacaremos a situação epidemiológica do tétano neonatal no País e no Estado, cuja meta de eliminação até 2003 não foi alcançada.

A notificação do tétano neonatal e acidental, separadamente foi iniciada a partir de 1982, observando-se um declínio na incidência de casos notificados até 1997, com redução dos coeficientes de incidência de 1,8 por 100 mil, para 0,02 por 100 mil, respectivamente. Esses índices não refletem as variações regionais, com altas taxas nas regiões Norte, Nordeste e Vale do Jequitinhonha, onde são patentes as dificuldades de acesso.

O tétano acidental vem se deslocando para faixas etárias mais avançadas, havendo necessidade de incentivar a vacinação nesses grupos, evitando-se a perda em anos de vida numa etapa produtiva.

No Brasil, o tétano acidental apresentou, no período de 1982 a 1998, uma tendência contínua à redução tanto do número de casos notificados, que passou de 2.226 para 661, quanto da sua taxa de incidência, que era de 1,8 por 100 mil habitantes, em 1982, e que caiu para 0,4 por 100 mil habitantes, em 1998, o que corresponde a uma redução percentual em torno de $75 \%$. Contudo, a letalidade da doença ainda é muito elevada, sendo, em média, 33\%, no período compreendido entre 1982 a 1997, enquanto nos países desenvolvidos situase na faixa de $10 \%$ a $17 \%$ (BRASIL, 1999a).

Podemos observar no País uma evidente tendência ao decréscimo do tétano neonatal (GRAF. 2). Em 1982, foram notificados 584, casos o que correspondeu a uma taxa de incidência de 0,15 por 1.000 menores de um ano. Esses valores, em 1991, passaram, respectivamente, para 267 e 0,08 por 1.000 menores de um ano, o que significou uma redução em torno de $45 \%$ na taxa de incidência. Entre 1992, quando se deu a implantação do Plano de Eliminação do Tétano Neonatal, e 2002, o número de notificações decresceu de 233 para 33 casos, ou seja, houve um declínio em torno de $86 \%$, sendo a taxa de incidência neste último 
ano de 0,02 por 1.000 menores de um ano. Entretanto a letalidade média, nesse mesmo período, foi superior a $61 \%$.

GRÁFICO 2 - Casos de tétano neonatal confirmados por ano no Brasil, entre 1986 e 2002.

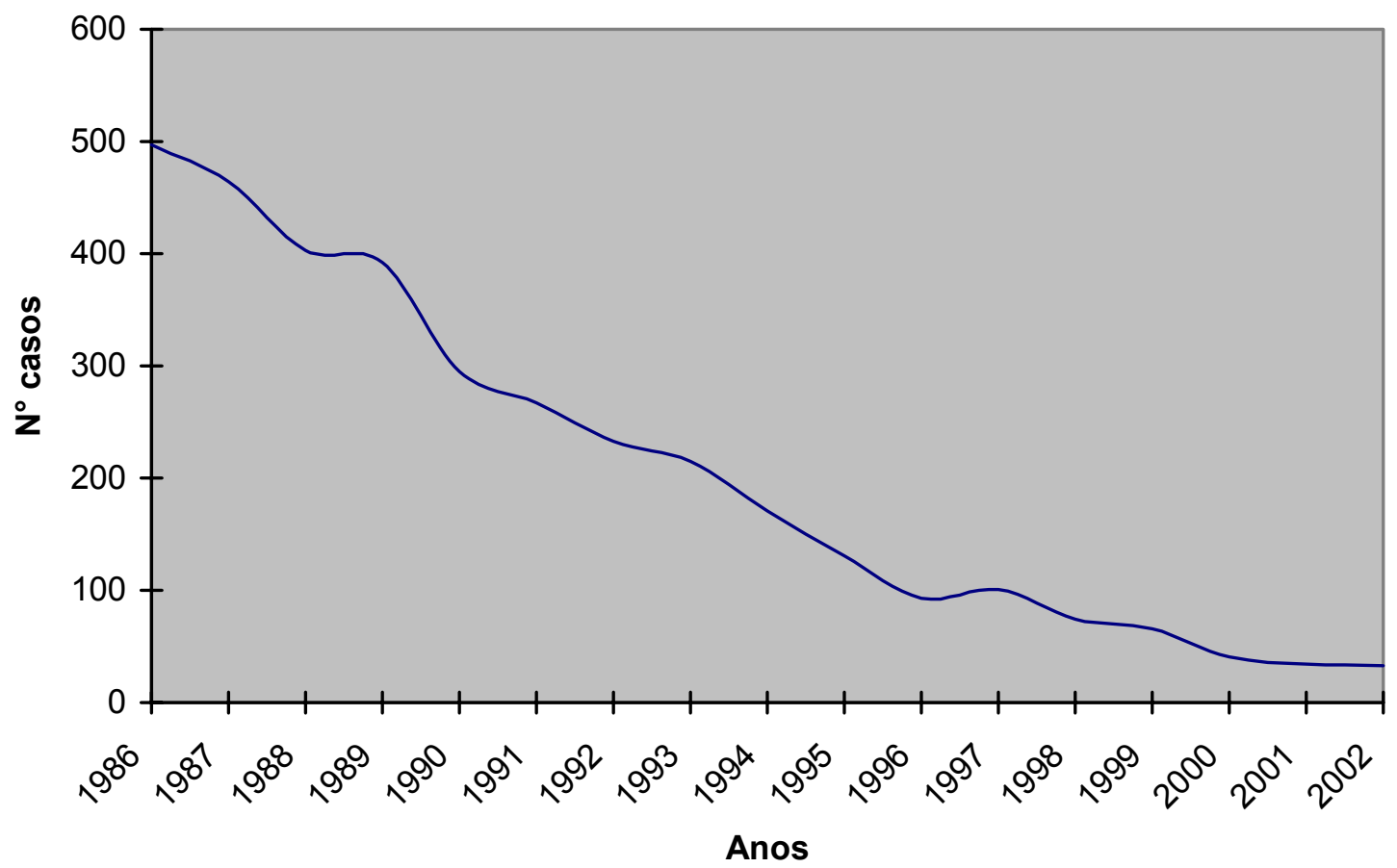

\begin{tabular}{|c|c|c|c|c|c|c|c|c|c|c|c|c|c|c|c|c|}
\hline 1986 & 1987 & 1988 & 1989 & 1990 & 1991 & 1992 & 1993 & 1994 & 1995 & 1996 & 1997 & 1998 & 1999 & 2000 & 2001 & 2002 \\
\hline 497 & 464 & 403 & 392 & 295 & 267 & 233 & 215 & 171 & 131 & 93 & 101 & 74 & 66 & 41 & 34 & 33 \\
\hline
\end{tabular}

Fonte: GT-Tétano/CNDI/CENEPI/FNS/MS.

As regiões com maiores taxas de incidência têm sido a Norte, a Nordeste e a Centro-Oeste. Na primeira, foram observados sempre os maiores riscos de adoecer, mas é no Nordeste que se encontra o maior número de casos, correspondente a, aproximadamente, $50 \%$ dos 1.459 casos confirmados no País, entre 1991 e 2002, sendo a Bahia, Ceará, Alagoas e Pernambuco os Estados que mais contribuíram para que isso acontecesse. No Centro-Oeste, Goiás destaca-se por apresentar maior número de casos. Na região Sudeste, o número de 
casos confirmados variou de 25, em 1995, a 3, em 2002; São Paulo registrou o último caso em 1999 e Minas Gerais apresenta-se como a Unidade Federada que exige maior atenção, por concentrar mais de $60 \%$ dos casos nessa região. No Sul, desde o início do período apontado, o número de registros de tétano neonatal é relativamente pequeno (93 casos de 1991 a 2002), quando comparado às outras regiões do País; entretanto, em alguns anos, a taxa de incidência da região mostra-se discretamente superior à da Região Sudeste (BRASIL, 1999a; BRASIL, 2004).

Em Minas Gerais, segundo dados da Coordenação de Doenças Transmissíveis e Imunização, observamos que, embora o número de casos venha diminuindo (GRAF. 3) e a taxa de incidência por tétano neonatal venha apresentando também uma queda ao longo dos anos, essa taxa ainda está bastante acima dos valores ideais para o País. Para 1998, essa taxa de incidência no Estado é de 1.85, índice próximo ao de 1982 no País, enquanto para 1998 a taxa era de 0.4 para 100 mil habitantes (MINAS GERAIS, 1999; LEMOS; RODRIGUES, 2003).

GRÁFICO 3 - Casos de tétano neonatal confirmados em Minas Gerais, entre 1993 e 2004.

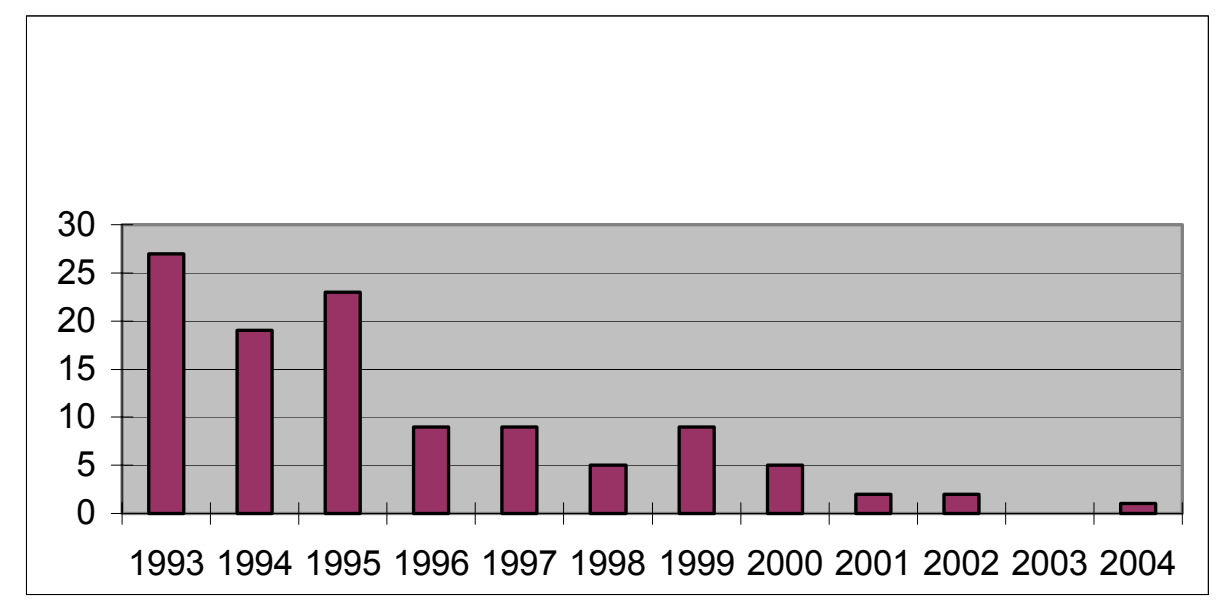

Fonte: Coordenação de Doenças Transmissíveis e Imunização/DVE/SE/SES-MG 
Fatores como o sucesso do Programa Nacional de Imunização, que completa 30 anos de implantação, melhoria da cobertura da assistência pré-natal, os treinamentos das parteiras tradicionais, como parte das ações do Programa de Assistência Integral à Saúde da Mulher, e a expansão do Programa Saúde da Família, estão certamente contribuindo para o Plano de Eliminação do Tétano Neonatal em Minas Gerais.

Há necessidade, porém, de implementar esforços estratégicos específicos, direcionados para a vigilância epidemiológica, capacitação de parteiras leigas, incremento dos serviços de pré-natal e ampliação de coberturas de vacinação para mulheres em idade fértil, principalmente nos municípios silenciosos e naqueles em que ocorreram os casos de tétano neonatal, o que poderá produzir um grande impacto epidemiológico e contribuir para a eliminação da doença.

Outro aspecto importante a ser considerado refere-se às Oportunidades Perdidas de Vacinação (OPVs). Segundo Brasil (1991), as OPVs consideradas consistem naquela “circunstância na qual uma pessoa que pertence a um grupo de risco, e encontra-se disposta a receber o benefício da vacinação", comparece a uma unidade de saúde e "não é vacinada".

As seguintes situações caracterizam as OPVs:

[...] - quando a vacinação não é realizada em qualquer contato que ocorra entre mulheres, crianças e o serviço de saúde;

- quando a vacinação é negada por falsas contra-indicações feitas por profissionais de saúde desatualizados quanto às normas do Programa Nacional de Imunizações;

- quando apenas uma vacina é aplicada e a indicação seria de duas ou mais, conforme estado vacinal e idade da criança;

- quando as mães, irmãs maiores ou outras responsáveis não são vacinadas com toxóide antitetânico, na hora que trazem uma criança ao serviço de saúde por qualquer motivo (BRASIL, 1991).

Como bem observou Gera (1998) em pesquisa realizada em Ribeirão Preto - SP, numa unidade básica de saúde, a vacinação não foi abordada na recepção, no agendamento e 
na aplicação de medicamentos. Nas consultas médicas, foi abordada em 34,4\% dos atendimentos. No "teste do pezinho" foi verificado o estado vacinal em todos os atendimentos, e na pós-consulta, na maior parte deles. Se na atenção à criança, a qual é tida como um dos programas prioritários do Ministério da Saúde, encontra-se uma elevada taxa de OPVs, o que se pode esperar desse indicador em relação aos programas de atenção a mulher e de modo particular em relação à vacinação antitetânica nas mulheres em idade fértil?

Ao considerarmos que o Brasil conseguiu erradicar a varíola e a poliomielite, bem como controlar o sarampo, torna-se perfeitamente viável a erradicação do tétano neonatal se houver decisão política e esforços nesse sentido.

Espera-se que por intermédio da Norma Operacional de Assistência à Saúde NOAS/SUS 01/02 -, que estabelece o processo de regionalização como estratégia de hierarquização dos serviços de saúde e de busca de maior eqüidade, seja implementado, no âmbito de estados e municípios, o Plano Diretor Regionalizado. Esse plano deverá garantir o acesso dos cidadãos, o mais próximo possível de sua residência, a um conjunto de ações e serviços que incluem, dentre outros: a) cobertura universal do esquema preconizado pelo Programa Nacional de Imunizações, para todas as faixas etárias; b) acompanhamento do crescimento e desenvolvimento infantil; c) a assistência pré-natal, parto e puerpério. 


\subsection{O PROGRAMA DE SAÚdE DA FAMíliA: UMA ESTRATÉGia PARA ATENÇÃO PRIMÁRIA DE SAÚDE}

A estratégia do Programa de Saúde da Família (PSF) foi iniciada no País em junho de 1991, com a implantação do Programa de Agentes Comunitários de Saúde (PACS). O PACS surgiu a partir de experiências exitosas, especialmente do Estado do Ceará, com o Programa de Agentes de Saúde, e hoje é compreendido como estratégia transitória para o PSF (MARQUES, 2001). Em janeiro de 1994, formaram-se as primeiras equipes de Saúde da Família, incorporando e ampliando a atuação dos agentes comunitários.

De acordo com dados do Departamento de Atenção Básica do Ministério da Saúde, em 2000 foram implantadas 8.604 equipes de Saúde da Família; em 2001 esse número saltou para 13.168; em 2002 para 16.698; em 2003 para 18.016. Até abril de 2004 são 19.943 equipes atuando em 4.565 municípios atingindo quase 60 milhões de pessoas, ou seja, 37,7\% da população brasileira (MACHADO, 2004).

O Programa de Saúde da Família como estratégia prioritária de operacionalização da implementação da atenção básica é compreendido como um mecanismo no processo de reorganização dos sistemas municipais de saúde, com a garantia de financiamento específico para a sua execução. A estratégia do PSF prioriza as ações de prevenção, promoção e recuperação da saúde das pessoas, de forma integral e contínua. O atendimento é prestado pelos profissionais que compõem as equipes de Saúde da Família na unidade básica de saúde ou no domicílio. Assim, esses profissionais e a população acompanhada criam vínculos de coresponsabilidade, o que facilita a identificação e o atendimento aos problemas de saúde da comunidade (BRASIL, 1994). 
Cada equipe do PSF é integrada por um médico, um enfermeiro, um auxiliar de enfermagem e agentes comunitários de saúde, que assumem a responsabilidade sanitária por determinada população a ela vinculada em um território onde vivem no mínimo 2.400 e no máximo 4.500 pessoas. O quantitativo de agentes varia de acordo com a população coberta pela equipe, tendo-se como parâmetro que cada agente poderá cobrir, no mínimo, 400 e, no máximo, 750 pessoas em uma microárea. Outros profissionais - a exemplo de dentistas, assistentes sociais e psicólogos - poderão ser incorporados às equipes ou formar equipes de apoio, de acordo com as necessidades e possibilidades locais. A Unidade de Saúde da Família pode atuar com uma ou mais equipes, dependendo da concentração de famílias no território sob sua responsabilidade.

A Unidade de Saúde da Família está inserida no primeiro nível de ações e serviços do sistema local de assistência, denominado atenção básica. Deve estar vinculada à rede de serviços, de forma que se garanta atenção integral aos indivíduos e famílias e que sejam asseguradas a referência e a contra-referência para clínicas e serviços de maior complexidade, sempre que o estado de saúde da pessoa assim exigir.

O acompanhamento das ações e os resultados das atividades realizadas pelas equipes do PACS/PSF são monitorados pelo Sistema de Informação de Atenção Básica (SIAB). Criado em 1998, é instrumento gerencial dos Sistemas Locais de Saúde, adotando como conceitos básicos território, problema e responsabilidade sanitária, completamente inserido no contexto de reorganização do SUS no País, o que fez com que assumisse características distintas dos demais sistemas existentes. Tais características significaram avanços concretos no campo da informação em saúde. Dentre elas, destacamos:

- microespacialização de problemas de saúde e de avaliação de intervenções;

- utilização mais ágil e oportuna da informação; 
- produção de indicadores capazes de cobrir todo o ciclo de organização das ações de saúde a partir da identificação de problemas;

- consolidação progressiva da informação partindo de níveis menos agregados para mais agregados.

O SIAB é um sistema de informação territorializado, cujos dados são gerados por profissionais de saúde das equipes de saúde da família, coletados em âmbito domiciliar e em unidades básicas nas áreas cobertas pelo PACS/PSF. O fato de a coleta de dados se referir a populações bem delimitadas tem possibilitado a construção de indicadores populacionais referentes às áreas de abrangência do Programa, que podem ser agregadas em diversos níveis.

A agregação dos dados confere grande agilidade ao Sistema, gerando uma informação oportuna no processo de decisão em saúde, o que tem sido apontado com uma de suas vantagens. Aliada a essa característica, o seu grande nível de desagregação favorece sua utilização como instrumento de planejamento e gestão local. Entre os diversos Sistemas de Informação em Saúde, é o que trabalha com o nível de desagregação das microáreas. O SIAB possui um amplo elenco de indicadores, permitindo a caracterização da situação sociossanitária e do perfil epidemiológico e o acompanhamento das ações de saúde desenvolvidas. Vale destacar que se trata do único sistema de informação de saúde que disponibiliza indicadores sociais, permitindo aos gestores municipais monitorar condições sociodemográficas das áreas cobertas, que só estão disponíveis nesse nível de desagregação nos anos censitários.

Os principais instrumentos de coleta do SIAB são: 
- ficha de cadastro das famílias e levantamento de dados sócio-sanitários, preenchida pelo agente comunitário de saúde (ACS) no momento do cadastramento das famílias, sendo atualizada permanentemente;

- fichas de acompanhamento de grupos de risco e de problemas de saúde prioritários, preenchidas mensalmente pelos agentes comunitários de saúde, no momento de realização das visitas domiciliares;

- fichas de registro de atividades, procedimentos e notificações, produzidas mensalmente por todos os profissionais das equipes de saúde.

Os dados gerados mediante fichas de coleta são, em grande parte, agregados, e alguns deles são consolidados antes de ser lançados no programa informatizado. Uma vez processados os dados, são produzidos os relatórios de indicadores do SIAB. São eles:

- Consolidado de famílias cadastradas - apresenta os indicadores demográficos e sociosanitários por microárea, área, segmento territorial, zona (urbana/rural), Município, Estado e Região;

- Relatório de Situação de Saúde e Acompanhamento das Famílias - que consolida mensalmente as informações sobre situação de saúde das famílias acompanhadas por área, segmento territorial, zona (urbana e rural), Município, Estado e Região;

- Relatório de Produção e Marcadores para Avaliação - que consolida mensalmente as informações sobre produção de serviços e a ocorrência de doenças e/ou situações consideradas como marcadoras por área, segmento territorial, zona (urbana e rural), Município, Estado e Região. 
Desde 2001, considerando os limites do SIAB, bem como a necessidade de racionalizar a coleta de dados no nível local e o número de sistemas e aplicativos, o MS vem trabalhando na perspectiva de disponibilizar um sistema de informação que amplie seu escopo e extrapole os limites do PACS/PSF. Ampliando o conceito da atenção básica e das atribuições desse nível de atenção, atualmente vem elegendo o que seria objeto de monitoramento a ser contemplado pelo sistema, de acordo também com a Política de Informação e Informática para o SUS.

As discussões avançaram no sentido do SIAB estar incorporando variáveis e indicadores essenciais para o monitoramento da atenção básica do SISPRENATAL, SISHIPERDIA, SIAPI, SIA e Sistema Bolsa-Alimentação além da integração com o Sistema Cartão Nacional de Saúde, Sistema do Cadastro Nacional de Estabelecimento de Saúde e Sistema do Cadastro Nacional de Usuários e Domicílios.

Inova ao trazer para o contexto do monitoramento as ações voltadas para a vigilância e a promoção da saúde. Nesse sentido, as discussões e definições têm passado por todas as áreas que têm interface com a atenção básica, garantindo os avanços do SIAB atual, já referidos anteriormente.

A etapa final de reformulação do SIAB está prevista para o primeiro semestre de 2004. A proposta que vem sendo desenhada e o acompanhamento nas secretarias estaduais e municipais de saúde integra a política de institucionalização da avaliação na atenção básica, contribuindo para a reorganização da atenção à saúde.

Ao completar dez anos de existência do Programa de Saúde da Família, durante os trabalhos da $2^{a}$ Mostra Nacional de Saúde da Família, realizada em Brasília de $1^{\circ}$ a 3 de junho de 2004, constatou-se que há muitos nós a desatar e arestas a aparar para uma execução plena, eficiente e eficaz do Saúde da Família. Dois pontos críticos foram destacados: 
primeiro, os recursos humanos, com a "desprecarização" do trabalho e a formação profissional adequada ao PSF; depois a avaliação e o monitoramento, pois ainda não há um processo de avaliação como instrumento efetivo (MACHADO, 2004).

$\mathrm{Na}$ avaliação do Ministério da Saúde dos casos de tétano neonatal ocorridos no País em 2002, sobre a existência de PSF/PACS na área de residência das mães, pode-se concluir que dos 31 casos ocorridos ( 1 caso em cada município), em 24 municípios os locais de residência estavam cobertos pelo PSF/PACS, apenas 4 localidades estavam descobertas e em 3 não foi possível obter essas informações (BRASIL, 2003).

Isso comprova a necessidade de que as equipes de Saúde da Família revejam suas estratégias de trabalho, avaliem as atividades realizadas e as que precisam ser implementadas em nível de cada município. Um dos passos fundamentais é a captação precoce de gestantes para o pré-natal e vacinação antitetânica, bem como a realização de visitas domiciliares para orientação e acompanhamento dos cuidados ao recém-nascido.

Em 1994, Minas Gerais iniciou a implantação do PSF, quando 12 municípios foram contemplados com recursos financeiros do Ministério da Saúde. A partir de 1998, o Estado passou também a trabalhar com o PACS como forma de o município iniciar o cadastramento das famílias, levantamento de problemas, estabelecimento de vínculo da população com o serviço de saúde para posteriormente transformá-lo em PSF.

Minas Gerais é o Estado com maior atuação do Programa de Saúde da Família (PSF) no Brasil. Em meados de 2004, 49\% da população mineira já era beneficiada com as ações do programa voltadas para a atenção básica. Eram 2.793 equipes espalhadas em 743 municípios. E a intenção da SES-MG é aumentar ainda mais a área de cobertura do programa. Em 2006, já com o nome de Saúde em Casa, o programa vai beneficiar cerca de $70 \%$ da população mineira (AMORIM, ARAÚJO, 2004). 
O PSF e o PACS constituem importantes estratégias e partes integrantes e fundamentais do SUS, que, embora venham avançando na atenção primária de saúde, não o fazem de modo uniforme em todos os municípios do Estado. Encontram diversos desafios, dentre os quais as dificuldades de financiamento, diferentes modalidades de contratação, carência e rotatividade de profissionais, falta de capacitação de pessoal e diferentes concepções do processo saúde-doença.

Pelo GRAF. 4 pode-se observar a evolução da implantação do PSF em Minas Gerais, ano a ano e por números de municípios:

GRÁFICO 4 - Número de equipes do Programa Saúde da Família e de municípios implantados em Minas Gerais, entre 1995 e 2004.

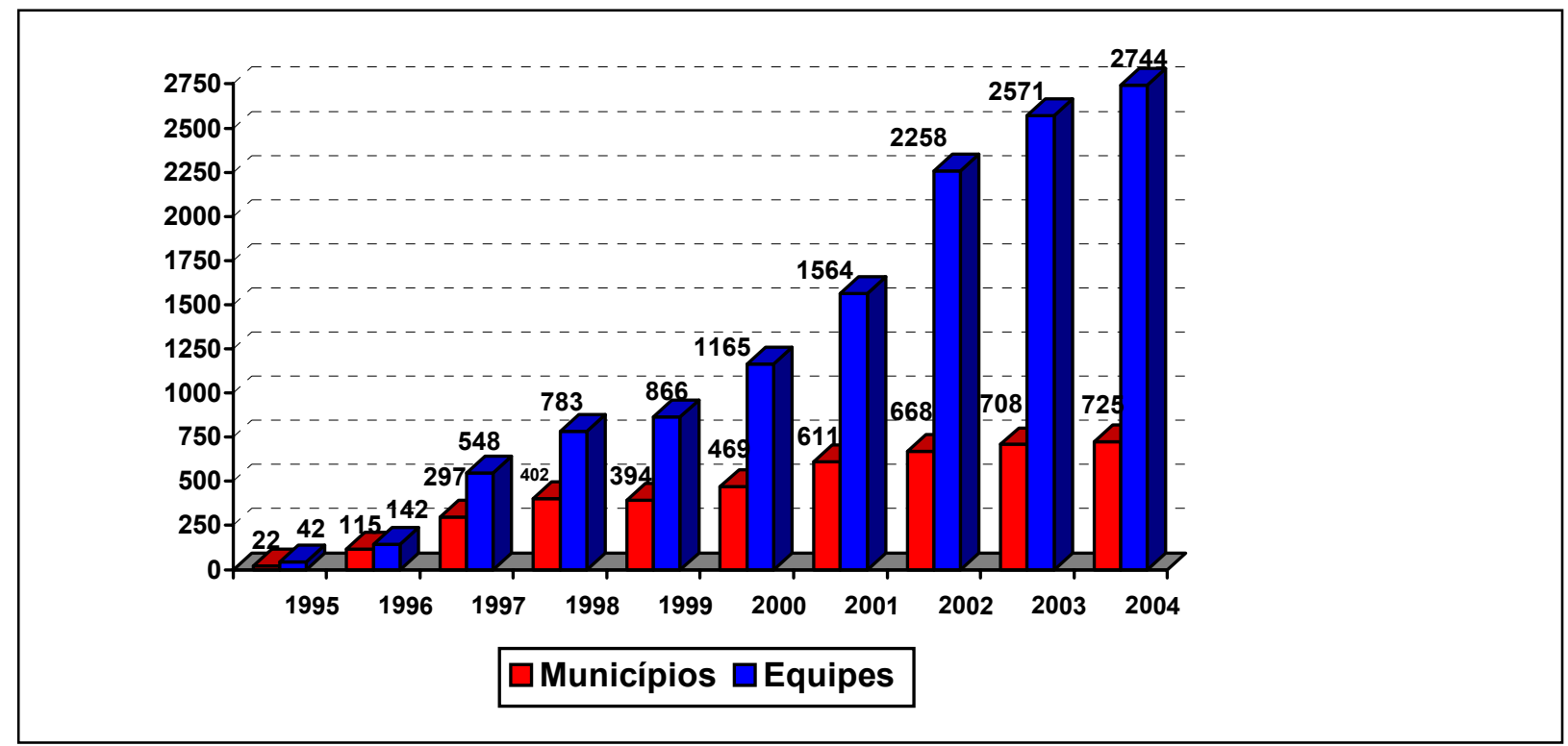

Pelos dados disponibilizados pela Coordenação do PSF em Minas Gerais, em dezembro de 2004 existiam 2.744 equipes com a participação de 17.352 Agentes Comunitários de Saúde (ACS). Já o Programa de Agentes Comunitários de Saúde estava presente em 76 municípios com 133 equipes e 2.258 ACS. 
Implantado em 725 municípios, o PSF está com uma cobertura de 55\%, pois para uma população de 17.109.579 habitantes residentes nestas áreas, pelo número de pessoas atendidas pelas equipes conforme dados contidos no Sistema de Informação da Atenção Básica (SIAB), verifica-se que 9.410.268 pessoas estão sendo contempladas com ações de saúde realizadas pelas equipes do PSF. Já o Programa de Agentes Comunitários de Saúde contempla 1.298 .350 pessoas, o que corresponde a $20 \%$ de cobertura para uma população de 6.488.364 habitantes.

Em depoimento, a Dra. Maria Rizoneide Negreiros de Araújo, Diretora da Atenção Básica/Programa Saúde da Família da Secretaria de Estado da Saúde de Minas Gerais, afirma:

Com a implantação das equipes de saúde da família, não resta dúvida que, houve um aumento significativo do número de consultas de pré-natal e puerpério, melhoria da cobertura vacinal antitetânica e nas orientações para a saúde do bebê. Porém não podemos dizer que houve uma melhoria na qualidade, porque as causas de morte ainda perduram, a exemplo da eclampsia, das infecções e das hemorragias. Isso demonstra a falta de capacitação técnica dos profissionais e também as dificuldades para referenciar para outros níveis de complexidade.

E complementa:

Em Minas Gerais apesar de ter uma boa cobertura vacinal da população materna, não há uma boa homogeneização, isto é, nem todos os municípios atingem os patamares desejáveis, acarretando alguns eventos indesejáveis, como a confirmação de casos de tétano neonatal, que marcam negativamente, a qualidade da atenção prestada pelas equipes da Atenção Básica/PSF.

Dos 22 municípios onde ocorreram óbitos por tétano neonatal de 1997 a 2002 (ANEXO 1), em 9 já havia o PSF quando o óbito ocorreu, em 12 a implantação ocorreu depois do caso e em 1 ainda não havia sido implantado o PSF. Independentemente da 
existência ou não do PSF no município e de equipe atuando na área onde ocorreu o caso de tétano neonatal, por se tratar de uma família de risco, a equipe de saúde deveria desencadear as ações previstas pela vigilância epidemiológica, dentre elas a vacinação de bloqueio nas imediações do domicílio. 


\section{Capítulo 3}

\section{METODOLOGIA}

Realizamos um estudo de caso do tipo quantitativo e qualitativo, no qual os dados quantitativos foram obtidos por intermédio das fichas de notificação, cadernetas de vacinação e cartões das gestantes e trouxeram importantes elementos para a visualização do cenário da pesquisa e a melhor compreensão das falas das mães.

Concordando com Minayo, acreditamos que,

[...] incluindo os dados operacionalizáveis e junto com o conhecimento técnico, qualquer ação de tratamento, e prevenção ou de planejamento deveria estar atenta aos valores, atitudes e crenças dos grupos a quem a ação se dirige. É preciso entender que, ao ampliar suas bases conceituais, as ciências sociais da saúde não se tornam menos científicas, pelo contrário, elas se aproximam com maior luminosidade dos contornos reais dos fenômenos que abarcam. MINAYO (1994, p.16).

Por isso, escolhemos trabalhar com as representações sociais sobre o adoecimento a partir da reconstrução da trajetória de mães de crianças que morreram por tétano neonatal.

Entendemos a nossa pesquisa como uma forma de indagar a realidade das mães com as suas representações sociais sobre o adoecer pelo tétano neonatal, de modo a compreender melhor esse problema e trazer contribuições para o controle da doença.

Nosso trabalho constituiu num estudo descritivo e exploratório, baseando-se em dados quantitativos e qualitativos.

Segundo Victóra (2000), os métodos quantitativos e qualitativos de pesquisa são diferentes, porém não são excludentes porque, na verdade, colocam-se questões diversas 
baseadas em construções teórico-metodológicas com princípios diferenciados. Portanto, é possível trabalhar de forma complementar com as duas metodologias, no sentido de que o resultado de uma questão, colocada a partir de princípios teórico-metodológicos quantitativos, suscite novas questões que só possam ser avaliadas sob princípios qualitativos, ou vice-versa.

Colaborando com o entendimento do princípio acima, Minayo afirma:

[...] Frente à problemática da quantidade e da qualidade a dialética assume que a qualidade dos fatos e das relações sociais são suas propriedades inerentes, e que quantidade e qualidade são inseparáveis e interdependentes, ensejando-se assim a dissolução das dicotomias quantitativo/qualitativo, macro/micro, interioridade e exterioridade com que se debatem as diversas correntes sociológicas (MINAYO, 1994, p.11-12).

Portanto, a dicotomia que se estabelece entre quantitativo/qualitativo, de um lado, deixa à margem relevâncias e informações que não podem estar contidas em números e, de outro lado, às vezes contempla apenas os significados subjetivos, omitindo a realidade estruturada.

\subsection{BASES DO ESTUDO}

Essa investigação seguiu o desenho metodológico de uma "Pesquisa Estratégica" por mostrar-se mais adequado ao alcance de nossos objetivos. Essa modalidade de pesquisa descrita por Minayo (1994), segundo a classificação alternativa de Bulmer, baseia-se nas teorias das ciências sociais e visa lançar luz sobre determinados aspectos da realidade, mesmo que estes não ofereçam soluções práticas para os problemas evidenciados. A pesquisa estratégica utiliza instrumentos teóricos e metodológicos da pesquisa básica, mas a sua 
finalidade é a ação. Por apresentar estas características "essa modalidade seria a mais apropriada para o conhecimento e avaliação de Políticas, e segundo nosso ponto de vista, particularmente adequado para as investigações sobre Saúde” (MINAYO, 1994, p.26).

A convite da Dra. Valéria Melo Rodrigues de Oliveira, superintendente de epidemiologia da SES-MG, em março de 2003 participei de reunião do Colegiado de Epidemiologia, com a finalidade de apresentar a proposta desta pesquisa para os coordenadores de epidemiologia das DADS. Na ocasião falei sobre o projeto e solicitei a colaboração dos coordenadores para o trabalho de campo.

Esta pesquisa foi submetida à apreciação do Comitê de Ética em Pesquisa da Universidade Federal de Minas Gerais (ANEXO 2), de acordo com as normas do Conselho Nacional de Saúde - Resolução n. 196, de 10 de outubro de 1996 - que regulamentam a pesquisa com seres humanos.

A pesquisa foi realizada em municípios das Diretorias de Ações Descentralizadas de Saúde de Minas Gerais, área onde se encontram 60\% dos casos notificados de tétanoneonatal da Região Sudeste, considerando ainda: o apoio técnico das diretorias de ações descentralizadas de saúde onde ocorreram os casos e a facilidade de acesso às fichas de notificação e atestados de óbitos, no sentido de favorecer a localização dos sujeitos para as entrevistas.

Para fazer parte da pesquisa, foram selecionadas mães cujas crianças morreram de tétano neonatal entre 1997 e 2002 (ANEXO 3), pois os depoimentos dessas pessoas poderão trazer as representações sociais sobre o adoecimento e a morte, permitindo construir uma trajetória que confronte o imaginário com a prática social.

Para o período 1997-2002 dispúnhamos de 26 casos notificados de crianças que evoluíram para óbito por tétano neonatal. O número de entrevistadas não foi definido a priori, 
e o critério de encerramento da coleta de informações foi pautado pela saturação dos dados, quando novos depoimentos não mais foram incluídos.

Os depoimentos foram colhidos por ordem cronologicamente inversa, ou seja, dos anos mais recentes para os anos mais distantes, pela menor possibilidade de mudança de endereço e também por questões relacionadas à memória da mãe. Foram entrevistadas 19 mães, pois 6 mães não foram localizadas em decorrência do paradeiro ignorado, e 1 criança não havia evoluído para óbito, ao contrário do que constava na ficha de notificação, e estava completando 5 anos por ocasião da entrevista. Essa constatação reforça o que Vieira (1998) já havia registrado em seu trabalho quanto à precariedade no preenchimento das fichas de notificação, apontando a necessidade de treinamento dos profissionais para essa atividade tão importante para a vigilância epidemiológica.

A coleta de informações foi feita mediante entrevista semi-estruturada, realizada individualmente, constando de cinco questões abertas norteadoras sobre o assunto. Sabe-se que esse tipo de instrumento proporciona ao entrevistado a livre expressão de suas representações (TRIVIÑOS, 1987).

Para isso, é necessário que o entrevistador proporcione tranqüilidade quanto aos objetivos da entrevista, de modo que o entrevistado se sinta à vontade e confortável para dar seus depoimentos (GARRET, 1981).

Assim propusemos como questões norteadoras:

1. Fale-me a respeito das suas gravidezes e dos seus partos.

2. O que você fez durante as gestações para que a senhora e seus bebês não tivessem problemas?

3. Alguma das suas crianças morreu? Fale-me a respeito.

4. O que a senhora fazia com o umbigo de seus bebês? 
5. A senhora sabe o que é o "mal-de-sete-dias" (tétano neonatal)?

Essas questões fizeram parte de um roteiro de entrevista no qual estão contidos também dados de identificação e alguns dados secundários (ANEXO 4). Foi realizado o teste piloto do roteiro de entrevista, o qual foi posteriormente avaliado pelo pesquisador, por Fernando Lefèvre e pela orientadora com a realização de alguns ajustes.

Os contatos iniciais foram realizados pelo pesquisador e por Lea Dulce de Souza, técnica em imunização da SES-MG, os quais acionaram as DADS, que por sua vez estabeleceram os contatos com as secretarias municipais onde residiam as mães que seriam entrevistadas.

Para a localização e o agendamento com as mães, contamos com a colaboração do agente comunitário de saúde, auxiliar de enfermagem, técnico de enfermagem ou enfermeiro, cujo contato com as entrevistadas foi fundamental no sentido de esclarecê-las e auxiliar na quebra de um possível estranhamento por ocasião das entrevistas.

Sempre fomos acompanhados de um agente comunitário de saúde, auxiliar de enfermagem, técnico de enfermagem ou enfermeiro, na maioria das vezes do sexo feminino, o qual já conhecia a mãe, o que foi fundamental tanto para a localização das residências, a maioria em áreas rurais longínquas e de difícil acesso, quanto para diminuir a estranheza quanto ao pesquisador, por ser do sexo masculino.

Um dos problemas metodológicos enfrentados foi a variação significativa da distância cronológica entre o evento pesquisado - o óbito da criança - e a fala das mães sobre ele, o que pode ter interferido na natureza de algumas informações prestadas ora próximas da emoção, ora distantes o suficiente para que pudessem ser elaboradas racionalmente. Assim, o 
tempo transcorrido entre o óbito e a entrevista em 7 casos foi maior de cinco anos, em 11 casos foi em torno de três anos e em 1 caso foi de um ano.

$\mathrm{Na}$ tentativa de contornar o problema, na realização das entrevistas, foram levadas em consideração as diferentes distâncias cronológicas do fenômeno pesquisado, prestando-se atenção nas duas possibilidades de equívoco na interpretação: de um lado, o viés do esquecimento; de outro, o viés da emoção diante da proximidade do evento. Para isso (minimizar este problema), foi fundamental a coleta de alguns dados secundários relativos ao caso.

Antes da realização das entrevistas, o objetivo do estudo e a importância da contribuição, ao participar da pesquisa, foram explicados às mães e familiares presentes. Além disso, foram esclarecidas quanto ao anonimato da participação, bem como quanto à liberdade de decidir em participar ou não da pesquisa. Todas as mães concordaram com a participação, registrando-a no termo de consentimento pré-informado e receberam sua via devidamente assinada pelo pesquisador (ANEXOS 5 e 6), preparado para esta finalidade, de modo a atender ao disposto na Resolução n. 196/96, do Conselho Nacional de Saúde.

Para o registro das entrevistas, com a aquiescência das entrevistadas, utilizou-se um microgravador com fitas magnéticas de 60 minutos cada.

As entrevistas foram realizadas por mim, no período de maio/2003 a agosto/2004, sendo feitas no domicílio da mãe, em dia e horário acertados previamente. Apenas uma mãe foi entrevistada fora do domicílio, na escola mais próxima de sua residência, pois no dia da entrevista chovia demais e o deslocamento só era possível a cavalo.

As recomendações de Alberti (1989) para a realização de entrevistas - “ambientes reservados, confortáveis e silenciosos" - não foram seguidas pela situação de pobreza, desconforto, falta de privacidade e falta de espaço em que viviam as mães entrevistadas. 
O tempo gasto para a realização do trabalho de coleta dos dados é explicado em razão dos 13.950 quilômetros percorridos, sendo aproximadamente 2.200 quilômetros em estradas não pavimentadas, para o deslocamento até os 18 municípios de residência das mães, já que duas mães residiam no mesmo município (FIG. 6). Em decorrência da intensidade e do longo período de chuvas foi necessário, na maioria das vezes, um motorista experiente e veículo com tração nas quatro rodas para se chegar às localidades rurais onde residiam as 19 mães. Essas localidades situavam-se entre 10 a 40 quilômetros do posto de saúde mais próximo, cujas vias de acesso ficam intransitáveis nos períodos de chuva, de modo que até o transporte escolar e o recolhimento de leite é interrompido.

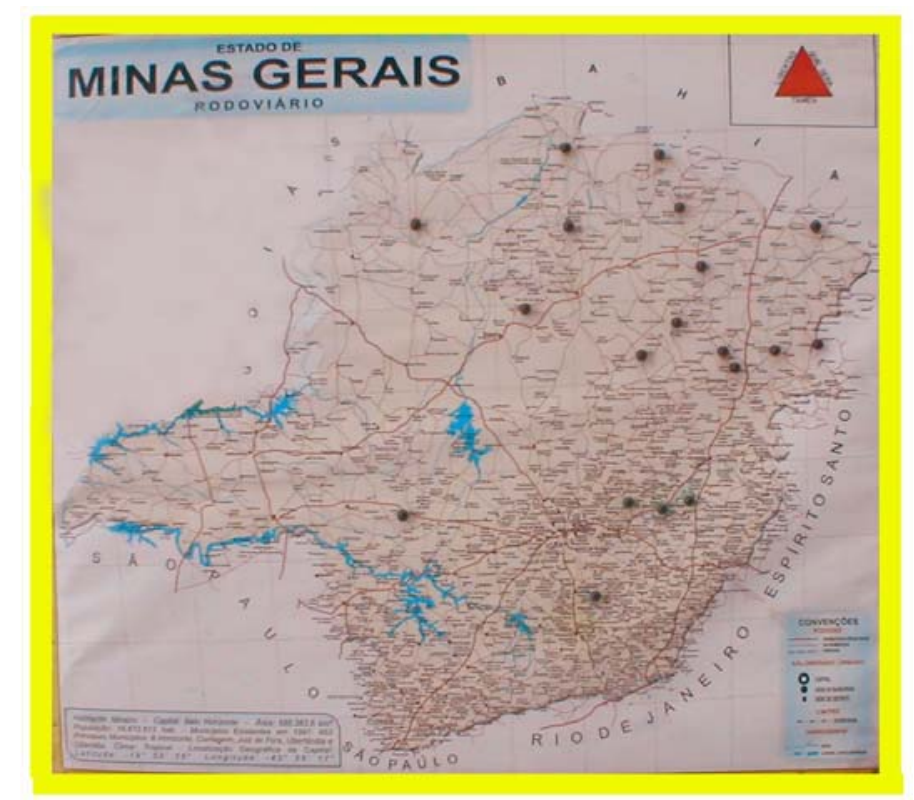

FIGURA 6 - Municípios de Minas Gerais por local de residência, dos 19 casos de óbito por tétano neonatal (1997-2002), cujas mães foram entrevistadas.

Observando o mapa acima e o ANEXO 3, chama atenção a forte concentração dos casos de TNN localizados nas regiões norte e nordeste do Estado, sendo oito deles na DADS 
de Montes Claros e quatro na DADS de Teófilo Otôni. Chama também atenção a ocorrência de casos da doença em DADS nas proximidades da Região Metropolitana de Belo Horizonte.

Não observamos nenhum tipo de constrangimento ou inibição por parte das mães entrevistadas. Acreditamos que o modo tranqüilo como os contatos e o agendamento foram feitos e a presença, por ocasião da entrevista, de um agente comunitário de saúde ou outro profissional de saúde que já as conhecia permitiam-lhes segurança e tranqüilidade para os depoimentos.

\subsection{MÉTODO DE ANÁLISE}

Antes de começar a transcrição dos dados, as fitas foram ouvidas várias vezes, para que se tivesse uma idéia panorâmica, visando à melhor compreensão das falas. Com os discursos gravados em fitas, procedeu-se à transcrição literal de todos os depoimentos orais. Cada uma das entrevistas recebeu um código (E), ficando assim denominadas: E1 = entrevista 1, E2 = entrevista 2, e assim sucessivamente, até E19 = entrevista 19.

Utilizou-se para a organização dos dados a proposta metodológica do Discurso do Sujeito Coletivo (DSC), uma nova abordagem na pesquisa qualitativa formulada por Lefèvre e Lefèvre (2000).

Esses autores afirmam que, qualquer que seja a técnica utilizada pelo investigador, uma vez que se trata de pesquisa qualitativa, os depoimentos são discursos que devem permanecer inalterados, isto é como qualidades, durante e depois do processamento. Processar depoimentos significa agrupar ou agregar elementos em conjuntos, ou seja, somar qualidades, 
qualitativamente. Portanto, a soma de discursos individuais dá como resultado um ou vários discursos do sujeito coletivo. Acrescenta-se, ainda, que o pensamento coletivo não está ligado ao somatório dos pensamentos individuais, portanto, a uma representação numérica percentual, mas ao discurso da coletividade, ao imaginário social, às representações sociais, ao pensamento preexistente.

O DSC visa, antes de tudo, fazer as devidas correlações que a coletividade traz nos seus discursos, que carregam valores intrínsecos, próprios da cultura, presentes no cotidiano dos sujeitos sociais.

A proposta implica a utilização de quatro figuras metodológicas, elaboradas para ajudar a organizar e tabular depoimentos e demais discursos, condição prévia e indispensável para uma boa análise e interpretação dos depoimentos.

As figuras são: as expressões-chave, a idéia central, a ancoragem e o discurso do sujeito coletivo.

- Expressões-chave - As expressões-chave (ECH) são pedaços, trechos ou transcrições literais do discurso, que devem ser sublinhados, iluminados, coloridos pelo pesquisador e que revelam a essência do discurso ou a teoria subjacente.

Busca-se, aqui, o resgate da literalidade do depoimento, elemento fundamental, pois, por meio dele o leitor é capaz - comparando um trecho selecionado do depoimento com a integralidade do discurso e com as afirmativas reconstruídas sob a forma de idéias centrais e ancoragens - de julgar a pertinência ou não da seleção e da tradução dos depoimentos. Portanto, as expressões-chave constituem uma espécie de "prova discursivo-empírica" da "verdade" das idéias centrais e das ancoragens, e vice-versa. 
Para Lefèvre e Lefèvre (2000), as expressões-chave são fundamentais para a confecção do DSC, portanto, é necessário que sejam coletadas com rigor e observação. Elas representam a veracidade do depoimento oral entre um trecho selecionado e as afirmativas reconstruídas, devendo-se julgar pertinente ou não a forma de traduzir discursivamente a ancoragem ou a idéia central.

- Idéia central - A idéia central (IC) é uma expressão lingüística que revela e descreve da maneira mais sintética, precisa e fidedigna possível o sentido de cada um dos discursos analisados e de cada conjunto homogêneo de $\mathrm{ECH}$, que vai dar nascimento, posteriormente, ao DSC.

É importante assinalar que a IC não é uma interpretação, mas uma descrição do sentido de um depoimento ou de um conjunto de depoimentos.

As ICs podem ser resgatadas mediante descrições diretas do sentido do depoimento, revelando "o que foi dito", ou por meio de descrições indiretas ou mediatas, que revelam o tema do depoimento ou "sobre o que" o sujeito enunciador está falando. Neste último caso, será preciso, depois da identificação do tema, delimitar a ou as IC(s) correspondentes.

Para efeito de análise dos depoimentos, Lefèvre e Lefèvre (2000) afirmam que a IC poderia ser entendida como a "síntese do conteúdo discursivo verbalizado pelos sujeitos". As afirmações, negações, e dúvidas a respeito da realidade presente, bem como os juízos de valor do cotidiano dos depoentes.

- Ancoragem - Algumas ECH remetem não apenas a uma IC correspondente, mas, também, a uma figura metodológica, que, sob a inspiração da teoria da representação 
social, os autores denominam ancoragem (AC), que é a manifestação lingüística explícita de uma dada teoria, ou ideologia, ou crença que o autor do discurso professa e que, na qualidade de afirmação genérica, está sendo usada pelo enunciador para "enquadrar" uma situação específica. É importante observar que todo depoimento tem uma ou várias ICs, mas apenas alguns apresentam, de maneira explícita, as marcas discursivas da ancoragem.

- Discurso do sujeito coletivo - O discurso do sujeito coletivo (DSC) é um discurso-síntese redigido na primeira pessoa do singular e composto pelas ECHs, que se originam de uma mesma IC ou AC.

Com o DSC, os discursos não se anulam ou se reduzem a uma categoria comum unificadora, já que o que se busca fazer é precisamente o inverso, ou seja, reconstruir, com pedaços de discursos individuais, como em um quebra-cabeça, tantos discursos-sínteses quantos se julgue necessário para expressar uma dada "figura", ou seja, um dado pensar ou representação social sobre um fenômeno.

O DSC é, assim, uma estratégia metodológica com vista a tornar mais clara dada representação social e o conjunto das representações que conforma um dado imaginário.

Nesse sentido, a proposta tem como finalidade analisar o material verbal coletado extraindo-se de cada um dos depoimentos orais as idéias centrais (IC) e as suas respectivas expressões-chave (ECH), e com essas duas, compor um ou vários discursos-síntese, que Lefèvre e Lefèvre (2000) denominam de discurso do sujeito coletivo (DSC). Parte-se dos discursos em estado bruto, que são submetidos a um trabalho analítico inicial de decomposição que consiste, basicamente, na seleção das principais ancoragens e/ou idéias centrais presentes em cada um dos discursos individuais e em todos eles reunidos, e que 
termina de forma sintética, na qual se busca a reconstituição discursiva da representação social. 


\section{Capítulo 4}

\section{RESULTADOS E DISCUSSÃO}

As informações registradas na primeira parte do Roteiro de Entrevista (ANEXO 3), principalmente em relação ao número de filhos, antes e depois da criança que morreu por tétano neonatal, situação vacinal antitetânica aferida no cartão de vacina da mãe e assistência pré-natal aferida no cartão da gestante foram fundamentais para a melhor compreensão das falas das entrevistadas.

Provavelmente em razão da baixa escolaridade, as mães tiveram dificuldades no fornecimento dos dados referentes ao número de consultas de pré-natal, doses de vacina e mesmo em relação à própria idade.

Das 19 mães entrevistadas, 6 não tinham nenhuma escolaridade, 11 estudaram entre 1 e 4 anos e 2 estudaram entre 5 e 8 anos. Do total das entrevistadas, 14 residem na zona rural e 5 na zona urbana.

Quanto ao número de gravidezes, apenas uma mãe era primípara, tendo como referência a época do nascimento da criança, que morreu por tétano neonatal (TNN), sendo as demais mães multíparas. A média atual de filhos é de 4,8 e a idade média das mães é de 33 anos. Uma das mães tinha 51 anos e a outra havia feito laqueadura, portanto uma população em idade fértil para a procriação.

Com relação à formação escolar, podemos afirmar que o nível de escolaridade das mães é muito baixo, realidade que condiz com o contexto em que vivem: qualidade de vida rural subdesenvolvida, onde predominam precários níveis socioeconômicos. 
Em estudo realizado por Medic (1999) sobre nascidos vivos que não tiveram assistência pré-natal ou cujo parto foi realizado no domicílio, segundo o nível de escolaridade da mãe, verificou-se que, para mulheres sem escolaridade, os percentuais alcançados nessas duas variáveis são próximos de $45 \%$ e $25 \%$, respectivamente, ao passo que, para mulheres com mais de 12 anos de estudo, o percentual cai para zero nas duas variáveis.

Quanto à profissão, 11 mães exerciam atividades do lar, além de cuidar de pequenos animais e da agricultura de subsistência, sendo o excedente da produção trocado por outras mercadorias para a sobrevivência da família. Uma das mães, além de ser do lar, exerce também a atividade de catadora de papel. As outras sete mães, além de serem do lar trabalhavam como diarista, sendo seis trabalhadoras rurais principalmente no plantio e na colheita da cana-de-açúcar, feijão e do café e uma ajudante de carvoaria. As mães que trabalham como diaristas relataram receber em torno de $\mathrm{R} \$ 8,00$ por dia, ao passo que os homens recebem $\mathrm{R} \$ 12,00$, o que mostra como o trabalho feminino é desqualificado em relação ao masculino. Não existe nenhum contrato formal de trabalho, de modo que a falta ao serviço por qualquer motivo significa perda do dia.

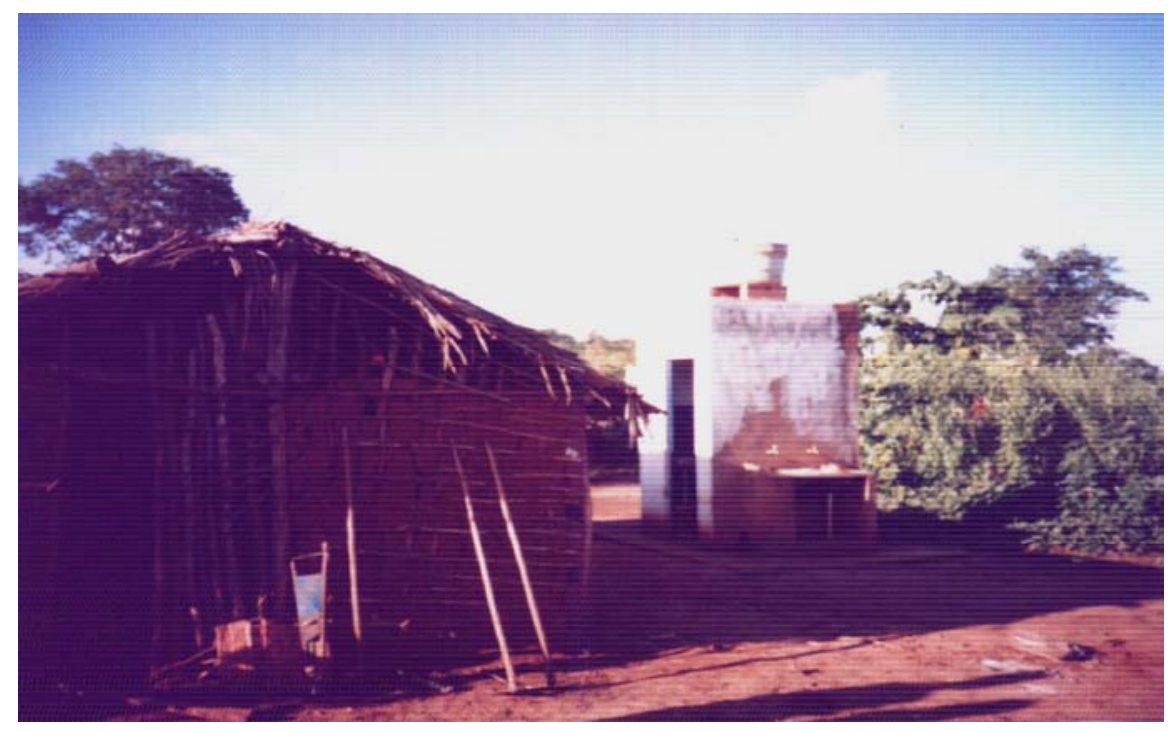

FIGURA 7 - Moradia típica das mães entrevistadas - Minas Gerais - 2004 
Em razão de o trabalho rural ser sazonal, acontecendo somente na época de colheita e plantio, as famílias ficam alguns meses sem a possibilidade de ganho financeiro nessa atividade. Os homens e até algumas mulheres costumam ir temporariamente para outras localidades distantes de casa, inclusive em outros estados, para conseguir trabalho no plantio ou colheita, onde permanecem por vários meses. Durante esse período, os pais costumam deixar seus filhos sob os cuidados de tias, avós ou outros parentes.

De modo geral, a renda familiar das entrevistadas gira em torno de um salário mínimo, de modo que as condições econômicas são bastante precárias, predominando moradias semelhantes à exemplificada na FIG. 7.

Apenas duas mães possuíam o cartão da gestante relativo ao pré-natal da criança que morreu por tétano neonatal, sendo que em ambos só constava o registro de uma consulta entre o sexto e o oitavo mês. Uma das mães afirmou ter queimado o cartão da gestante com todos os documentos da criança e que consultou apenas uma vez.

Em estudo realizado pelo Ministério da Saúde sobre os 64 casos de tétano neonatal ocorridos no País em 2001 e 2002, com referência ao número de consultas de prénatal das mães das crianças, verificou-se que 49 mulheres não realizaram nenhuma consulta, 2 mulheres realizaram uma consulta, 5 realizaram duas consultas, 1 realizou três consultas e somente 6 referiram quatro consultas e mais (BRASIL, 2003).

A situação vacinal das mulheres entrevistadas no momento da ocorrência do caso de tétano neonatal demonstrou que 11 mães não haviam tomado nenhuma dose da vacina dupla adulto (dT) e 3 tomaram apenas uma dose, insuficiente para proteger o $\mathrm{RN}$ contra o tétano neonatal. Duas mães tomaram duas doses de Dupla Adulto e 3 mães tomaram três doses, dado que pode estar relacionado ao rigor exigido com a conservação, ou seja, a cadeia de frio, ou quanto à validade das vacinas, técnica da aplicação, situação que pode 
comprometer o processo de imunidade. Outro ponto a ser destacado é que até o momento da realização da entrevista 4 mães permaneciam sem vacinar, 3 mães haviam tomado somente uma dose de Dupla Adulto e 5 permaneciam com as vacinas irregulares, ou seja, sem proteção para futuras gestações em relação ao tétano neonatal. Lembramos que a maioria da população entrevistada apresenta idade fértil, trabalha em atividade rural, expondo-se também ao risco do tétano acidental. Os dados apontam para a ocorrência de oportunidades perdidas de vacinação (OPV), pois a maioria das mulheres é multípara e provavelmente teve contato com os serviços de saúde em algum momento anterior, conforme se verifica na TAB. 1, a seguir:

\section{TABELA 1}

Situação das mães em relação à vacina dupla, tendo como referência o momento da ocorrência do caso de óbito por tétano neonatal (TNN) e no momento da entrevista - Minas Gerais - 1997 a 2002.

\begin{tabular}{l|c|c}
\multicolumn{1}{c|}{$\begin{array}{c}\text { NÚMERO } \\
\text { DE DOSES }\end{array}$} & $\begin{array}{c}\text { NO MOMENTO DA } \\
\text { OCORRÊNCIA DO CASO } \\
\text { DE ÓBITO POR TNN }\end{array}$ & $\begin{array}{c}\text { NO MOMENTO DA } \\
\text { ENTREVISTA }\end{array}$ \\
\hline 1 dose & 3 & 3 \\
\hline 2 doses & $2^{(*)}$ & 5 \\
\hline 3 doses & $3^{(*)}$ & 7 \\
\hline Nenhuma dose & 11 & 4 \\
\hline TOTAL & 19 & 19 \\
\hline
\end{tabular}

(*) Possibilidade de problema na cadeia de frio ou na técnica de aplicação da vacina dT. Fonte: Cartão de vacina das mães entrevistadas.

Reportando ao mesmo estudo do Ministério da Saúde, na análise dos 64 casos de tétano neonatal ocorridos no País de 2001 e 2002, 46 mulheres nunca foram vacinadas contra tétano, 9 receberam apenas uma dose válida e 5 receberam três doses e mais. Das 6 mães que fizeram 4 consultas e mais de pré-natal, 5 não receberam nenhuma dose da vacina e 1 mãe recebeu apenas uma dose (BRASIL, 2003). 
Neste trabalho, aponta-se, também, elevado número de mães cujos filhos adoeceram por tétano neonatal, embora tivessem tomado a vacina dupla, bem como algumas que receberam número de doses insuficientes e algumas que, embora tenham recebido número de doses suficientes e o processo de imunização foi comprometido, talvez, em decorrência de problema na cadeia de frio ou da técnica de aplicação. Aqui também é aplicável o conceito de oportunidades perdidas de vacinação (OPV).

A seguir, serão referidas as representações sociais das entrevistadas, tendo como instrumento a descrição das "idéias centrais" e as "expressões-chave" para cada resposta diante da pergunta formulada.

Foram listadas, em um único instrumento de análise de discurso (IAD2) todas as idéias centrais e todas as expressões-chave para cada um dos sujeitos, relativo às mesmas respostas para cada uma das cinco perguntas da entrevista, com total resgate da literalidade dos sujeitos em questão. A localização das expressões-chave demandou várias releituras das entrevistas, tendo em vista que, em muitas ocasiões, pensamentos que respondiam determinadas questões estavam nas falas das mães. O passo seguinte foi reunir em torno de uma ou mais "idéias centrais" esses pensamentos expressos, buscando sempre preservar a fidelidade deles. 
Desenvolvimento do Instrumento de Análise de Discurso - 2 (IAD-2)

\section{Fale-me a respeito das suas gravidezes e dos seus partos}

\section{A Parto atendido por parteira e realizado em casa}

\begin{tabular}{|l|}
\hline \multicolumn{1}{|c|}{ Idéia central } \\
\hline Quem fez o parto da criança que morreu foi a dona que \\
morava aqui. Em todas as gravidezes e em todos os \\
partos eu fui bem. Ganhei todos os meninos em casa. \\
Sempre quem me atendeu foi a minha mãe, porém ela \\
está muito velha e não atende mais.
\end{tabular}

E.1 Bem nas minhas gravidez eu fui bem. Nos partos, também, eu ganhei os meninos tudo aqui. [...] Eu não ganhei no hospital, foi em casa. Todas as gravidez chegaram até o final. Sempre quem me atendeu era a minha mãe. Minha mãe [...] me ajudava muito bem. Da que morreu quem fez o parto foi uma dona que morava aqui [...] não foi a minha mãe, não. [...] Ela não mexe com isto mais não, e ela é velha demais também.

Dessa criança foi meu marido quem fez o parto, porque a parteira não morava mais aqui. Mas não foi por isso que ela morreu. Eu tive todos eles aqui, e quem fez os outros partos foi uma mulher que mora lá.

Foi a minha sogra que me socorreu e fez o meu parto. Não deu tempo de eu ir para o hospital. Foi tudo normal. Ela já fez muitos partos e nunca houve problema.

E.5 [...] De todos esses menino eu ganhei eles tudo aqui, do mesmo modo que da outra. [...] Quem fez os parto foi uma mulhé que mora lá. Foi, só foi dessa outra que foi Dalvino, porque num tinha gente. Que a mulhé num tava mais aqui. Num achô. [...] Mas num foi por isso que ela morreu não. Foi porque deu mal-de-sete-dia mesmo.

E.7 Foi a minha sogra. Ela... Num deu tempo e ai ele foi buscá. [...] Mas quando ele ia chegando com a mãe dele, já tava quase nascendo a criança. [...] Aí ela me socorreu e também fez o meu parto. E foi tudo normal, tudo certinho, tudo em orde. [...] E ela já fez de muitas crianças e todos, Graças a Deus, foi muito feliz. Nunca deu poblema não.

Foi a minha mãe que pegou todos os meus filhos. Ela era a parteira velha. Deus ajudou que deu certo aqui em casa mesmo. Só um filho meu que nasceu atendido por médico.

Foi a minha mãe que acompanhou os partos, depois que a minha avó morreu. Foi tudo normal. Eu ganhei quase todos na roça; apenas a mais velha foi na cidade.

Foi a parteira que fez o parto do menino que morreu. Eu acho que não cortou o umbigo dele direito. Em todas as gravidezes correu tudo bem.

Foi meu marido que fez o parto desse filho que morreu, porque a parteira estava viajando e não veio cuidar dele. Mas não foi por isso que ele morreu. Ele usou a tesoura da casa para cortar o umbigo. Nunca tive meus filhos em hospital. Todos nasceram em casa. A parteira sempre fez tudo certinho.
E.8 [...] Mas Deus me ajudou que deu certo aqui em casa mesmo. É a minha mãe. Que ela era, era a parteira velha. Esses filho tudo meu foi a minha mãe que pegava. Só um filho que eu tenho que passô na mão de doutô.

E.10 [...] Eu ganhei eles tudo foi na roça, só da mais velha que foi em Taiobeiras. Foi normal, bom, né? Foi tudo normal. Foi a minha mãe. É que foi a minha vó. Depois que a minha vó morreu, foi a minha mãe que acompanhava.

E.11 Sempre minhas gravidez foi ótimo. É assim... Nunca teve nada, e também é, os parto foi tudo normal, Graças a Deus. Quem fez os meus parto? Foi as enfermeiras ... Ah, os médicos lá de Coração de Jesus, lá do hospital mesmo. Do menino que morreu foi Dona Maria. Foi Dona Maria de Oliveira. Foi ela que fez o meu parto, dele. Eu acho que num cortô o umbigo dele direite. Num queimô, eu acho? [...] Ela sempre fazia, né?. E num dava poblema nenhum assim não.

E.12 [...] A parteira veio e cuidô em casa. Não precisô deu ir nada, pra ganhá na rua, né? [...] Fez tudo certinho! [...] E esse que morreu ela não veio cuidar. A parteira num tava em casa. A parteira tava viajando, né? [...] Foi meu marido que fez o parto. Ele usô tesoura, né? Usô tesoura da casa. Passô, ele passô álcool nela todinha. [...] Nunca ganhei em hospital não. Foi tudo em casa. 


\begin{tabular}{|l|l|}
\hline \multicolumn{1}{|c|}{ Idéia central } & \multicolumn{1}{|c|}{ Expressões-chave } \\
\hline $\begin{array}{l}\text { Não havia hospital perto de casa para acudir a gente. } \\
\text { Então, foi a minha tia que fez os partos; ela é como } \\
\text { uma enfermeira. Todos os partos foram normais. }\end{array}$ & $\begin{array}{l}\text { E.13 Assim quando é... quando eu fui, tava espe... } \\
\text { sentindo dor pra ganhar o menino? Não, quem tava } \\
\text { mais eu era a minha tia, Tia Conceição. [...] Num tinha } \\
\text { assim hospital assim perto pa, pa gente acudir né? Os } \\
\text { parto assim pa, foi normal. [...] Foi a minha tia. Ela é } \\
\text { igual uma enfermeira mesmo (Risos). [...] O que morreu } \\
\text { eu ganhei foi em casa, né? Um eu ganhei no Pavão, o } \\
\text { outro eu ganhei no hospital. }\end{array}$ \\
\hline $\begin{array}{l}\text { Foi Marilene que apanhou o menino. A parteira } \\
\text { Leonarda era quase como uma médica. Em todas as } \\
\text { gravidezes correu tudo bem. As gravidezes foram } \\
\text { normais. Só um parto foi no hospital. Os outros foram } \\
\text { parteiras que fizeram. }\end{array}$ & $\begin{array}{l}\text { E.14 As minhas gravidez, tudo foi normal né? Tudo foi } \\
\text { normal. A primeira gravidez foi uma mulherzinha } \\
\text { chamada Delminda né? [...] E a terceira, segunda, foi } \\
\text { Leonarda, uma parteira lá, que era muito entendida, } \\
\text { era tipo quase que uma médica. E a terceira foi a Dona } \\
\text { Dercília, que mora ali. E o outro foi uma mulhé que } \\
\text { morava nessa casa aqui, oh! A mãe da Vaininha, a } \\
\text { Marilene, ela é que panhô o menino. E esse aqui eu } \\
\text { ganhei no hospital, em Maxacalis. }\end{array}$ \\
\hline $\begin{array}{l}\text { Foi minha cunhada quem fez o parto desse que morreu } \\
\text { com tétano. Foi falta de responsabilidade dela, pois, } \\
\text { segundo meus filhos, ela cortou o umbigo com uma } \\
\text { faca. Só três eu ganhei no hospital; os outros foram em } \\
\text { casa. }\end{array}$ & $\begin{array}{l}\text { E.17 Foram tudo bom. É não teve problema. [...] Só } \\
\text { treis que eu ganhei no hospital; o resto foi tudo em } \\
\text { casa. A minha mãe protegeu bastante na gestação, na } \\
\text { gravidez, depois que eu ganhei, né? Ela cortava com a } \\
\text { tesoura. [...] Esse que tô falando que morreu de tétano, } \\
\text { esse foi falta de responsabilidade da minha cunhada, } \\
\text { né? [...] Ia dizendo os meus meninos que viu ela } \\
\text { cortando com uma faca. }\end{array}$ \\
\hline
\end{tabular}

Das idéias centrais agrupadas, resultantes das falas muito heterogêneas das mulheres que compõem o grupo cujo parto foi realizado em casa e atendido por parteira, obtivemos os seguintes "discursos dos sujeitos coletivos":

1 - Quem fez o parto da criança que morreu foi a dona que morava aqui. Em todas as gravidezes e em todos os partos eu fui bem. Ganhei todos os meninos em casa. Sempre quem me atendeu foi a minha mãe, porém ela está muito velha e não atende mais.

2 - Foi a parteira que fez o parto do menino que morreu. Eu acho que ela não cortou o umbigo dele direito. Em todas as gravidezes correu tudo bem.

3 - Foi a minha mãe que acompanhou os partos, depois que a minha avó morreu. Foi tudo normal. Eu ganhei quase todos na roça; apenas a mais velha foi na cidade. 
4 - Foi a minha sogra que me socorreu e fez o meu parto. Não deu tempo de eu ir para o hospital. Foi tudo normal. Ela já fez muitos partos e, graças a Deus, nunca deu problema.

5 - Não havia hospital perto de casa para acudir a gente. Então, foi a minha tia que fez os partos; ela é como uma enfermeira. Todos os partos foram normais.

6 - Foi meu marido que fez o parto desse filho que morreu, porque a parteira estava viajando e não veio cuidar dele. Mas não foi por isso que ele morreu. Ele usou a tesoura da casa para cortar o umbigo. Nunca tive meus filhos em hospital. Todos nasceram em casa. A parteira sempre fez tudo certinho.

7 - Foi minha cunhada quem fez o parto desse que morreu com tétano. Foi falta de responsabilidade dela, pois, segundo meus filhos, ela cortou o umbigo com uma faca. Só três eu ganhei no hospital; os outros foram em casa.

A gravidez e o nascimento são percebidos pela mulher da zona rural com naturalidade, talvez pelas repetidas vezes em que os partos foram realizados em casa por parteiras, pela oportunidade de estar acompanhando mais de perto outros nascimentos nos domicílios vizinhos e até mesmo pelo maior contato com a natureza, onde os animais também lhes permitem ver o nascimento como um processo fisiológico.

A parteira geralmente vive o dia-a-dia de maneira semelhante ao das outras mulheres, compartilha as mesmas inquietações e assume papéis semelhantes na comunidade, participando do mesmo sistema religioso e cultural das mulheres assistidas, portanto há uma identidade concreta entre ambas (mulher/parteira). As entrevistadas comparam a competência das parteiras à dos médicos e enfermeiros.

Para a mulher que reside na zona rural, principalmente aquela que mora em lugares mais distantes, a única opção é o parto domiciliar realizado pelas parteiras. No 
entanto, nem sempre a família da parturiente consegue contatar a tempo uma parteira experiente, de modo que, dependendo da situação, alguma parente ou amiga faz o parto. Se obtiver êxito, fica conhecida na região como parteira e, a partir daí, passa a ser requisitada com freqüência. Algumas vezes o próprio esposo, por ter acompanhado algum dos partos anteriores e por não conseguir contatar uma parteira, vê-se na situação de ter que "apanhar" a criança.

Desse modo o acompanhamento do parto nas zonas rurais é ainda executado por parteiras e também por elementos do próprio grupo familiar. São, na maioria, mulheres leigas, que aprenderam o ofício ${ }^{5}$ acompanhando as avós, ou as mães, ou sozinhas, impelidas pela necessidade. A atuação das parteiras concentra-se, principalmente, nas regiões do Estado que têm os mais baixos índices de desenvolvimento humano (IDH) ${ }^{6}$ e altas taxas de mortalidade materno-infantil, quadro este que vem melhorando em Minas Gerais com o início em 2002 do processo de capacitação de parteiras tradicionais.

A experiência com capacitação das parteiras se baseia no guia, o Livro da Parteira e no manual Trabalhando com Parteiras Tradicionais, ambos revisados com a participação de vários profissionais e organizações, e publicados pelo Ministério da Saúde mediante proposta de conteúdo unificado e de estratégias para a educação continuada, com uma metodologia lúdica e vivencial (JUCÁ; MOULIN, 2002).

De acordo com Loyola, devemos fazer uma distinção entre as parteiras e as curiosas. As curiosas são simples auxiliares sem verdadeira competência, às quais as parteiras pedem ajuda em casos mais difíceis ou quando estão impossibilitas de atender a algum chamado (LOYOLA, 1984, p. 118). De modo que quando as curiosas, sem ter acompanhado

\footnotetext{
${ }^{5}$ Segundo Ferreira, ofício é a ocupação manual ou mecânica a qual supõe certo grau de habilidade que é útil ou necessária a sociedade (FERREIRA,1999)

${ }^{6}$ Criado em 1990 por iniciativa da Organização das Nações Unidas (ONU), o Índice de Desenvolvimento Humano (IDH) é um número que reflete as condições de três variáveis básicas para uma qualidade de vida digna, a expectativa de vida ao nascer, a escolaridade e o produto interno bruto per capta. Maiores informações em: www.idhnaweb.rg3.net.
} 
as parteiras, portanto ainda inexperientes, resolvem fazer um parto, há o risco de ocorrer algum tipo de problema.

Para Dias (2002), quando as parteiras atribuem valor econômico ao serviço prestado - embora seja raro acontecer -, esse valor não é baseado nas dificuldades encontradas, na carga de trabalho, na sua própria condição financeira e de saúde. Ao contrário, o critério de valor é a situação econômica da família envolvida no nascimento, em que as relações do cuidado se baseiam em valores morais, religiosos e afetivos, assim como no companheirismo, no acolhimento, na solidariedade e nas relações de parentesco, que são compartilhadas pela parteira e pela própria comunidade da qual faz parte, gerando maior confiança e credibilidade.

\section{B Parto atendido por profissional de saúde e realizado em hospital}

\begin{tabular}{|c|c|}
\hline Idéia central & Expressões-chave \\
\hline $\begin{array}{l}\text { Do que morreu, eu estava muito ruim, por isso eu tive } \\
\text { de ir para o hospital. Tive eclampsia. Ele não tinha } \\
\text { problema nenhum. }\end{array}$ & $\begin{array}{l}\text { E.2 [...] Igual eles fala, esse que morreu totalmente foi } \\
\text { no Siderúrgica. [...] desse que morreu eu fui muito, eu } \\
\text { tava muito ruim, eu fui obrigado a ir, ir pro Siderúrgica } \\
\text { porque que o poblema, meu poblema era clampis que } \\
\text { deu em mim né? [...] Aquele menino, eu já ganhei ele, } \\
\text { [...] ele num tinha poblema nenhum. [...] tô boba até } \\
\text { hoje com o negócio daquele menino. }\end{array}$ \\
\hline $\begin{array}{l}\text { Foi o médico que fez o parto. Correu tudo bem. O pré- } \\
\text { natal e o parto das duas crianças foram com o mesmo } \\
\text { médico. }\end{array}$ & $\begin{array}{l}\text { E.3 Num teve perigo não e o parto também correu tudo } \\
\text { bem.[...] E no parto correu tudo bem, correu tudo bem } \\
\text { no parto. [...] O tratamento e a gravidez foi tudo com } \\
\text { um médico só e correu tudo bem das duas. }\end{array}$ \\
\hline $\begin{array}{l}\text { Foi uma médica que fez meu parto. Os partos foram } \\
\text { normais, só que a médica não cuidou dele direito. }\end{array}$ & $\begin{array}{l}\text { E.4 Uai, foi bom. Eu tive duas filha. Os parto foi } \\
\text { normal, normal. [...] Agora a médica num olhô direito. } \\
\text { Mas só que eu num tenho nenhuma comigo. Deus levô } \\
\text { todas as duas. [...] Agora também eu tô grávida de } \\
\text { novo. Eu tô fazendo as consulta já. Pra vê se não dá } \\
\text { poblema, né? Igual teve com as outras. }\end{array}$ \\
\hline $\begin{array}{l}\text { Eu não sei o nome da enfermeira que fez meu parto. } \\
\text { Uma parte foi em São João da Ponte e a outra foi em } \\
\text { Montes Claros. Os partos foram normais. }\end{array}$ & $\begin{array}{l}\text { E.6 Ah, os que eu tive foi normale. [...] Um cado foi ai } \\
\text { na Ponte e um cado foi em Montes Claros. A menininha } \\
\text { foi em Montes Claros. Ela nasceu foi em Montes Claros. } \\
{[\ldots] \text { Eu num sei nem mesmo como a enfermeira chama. }}\end{array}$ \\
\hline
\end{tabular}




\begin{tabular}{|c|c|}
\hline Idéia central & Expressões-chave \\
\hline $\begin{array}{l}\text { Eu nem me lembro mais do nome do médico que fez } \\
\text { meu parto. Eu senti muitas dores, mas o parto foi } \\
\text { normal. Eu estou impressionada até hoje com a morte } \\
\text { desse meu filho. }\end{array}$ & $\begin{array}{l}\text { E.9 Dele é, passei muitas dores, que eu não consegui } \\
\text { ganhar em casa. Tive de ir pra cidade. O parto foi } \\
\text { normal. O parto foi normal. Eu nem me lembro mais } \\
\text { quem era o Doutô não. }\end{array}$ \\
\hline $\begin{array}{l}\text { Eu acho que quem fez meus partos foi enfermeira. Os } \\
\text { partos foram ótimos. Eu ganhei todos os meus filhos } \\
\text { no hospital. }\end{array}$ & $\begin{array}{l}\text { E.15 Meus partos foi... Um foi bom. Aliás dois partos foi } \\
\text { ótimo. Só que um que teve complicação. [...] Que eu } \\
\text { ganhei eles tudo foi no hospital, foi no hospital. [...] Eu } \\
\text { acho quem que fez meu parto foi enfermeira. Fez meu } \\
\text { parto foi enfermeira. [...] Aí num fala o nome? }\end{array}$ \\
\hline $\begin{array}{l}\text { Todos os meus filhos nasceram no hospital. Na } \\
\text { segunda gravidez eu perdi líquido, então a criança } \\
\text { nasceu fraca e teve parada cardíaca. }\end{array}$ & $\begin{array}{l}\text { E.16 Do primeiro até foi até normal meu parto, sentia } \\
\text { bem, não sentia nada, mas da, dessa que igual eu te } \\
\text { falei que eu perdi, a segunda, aí eu senti assim sabe? Eu } \\
\text { num sabia, tava perdendo líquido, então pra mim era } \\
\text { normal, então eu fiquei em casa, num procurei, um erro } \\
\text { meu que eu num procurei, eu não falei pro médico. Ai } \\
\text { então aconteceu, que ela nasceu fraca e com } 18 \text { dias de } \\
\text { vida, então ela deu parada cardíaca. No terceiro foi } \\
\text { normal também. [...] Todos meus } 3 \text { filhos nasceu no } \\
\text { hospital. }\end{array}$ \\
\hline $\begin{array}{l}\text { Foi a enfermeira que fez meu parto Foi tudo normal. } \\
\text { Porém, perdi dois meninos e a menina que teve tétano. } \\
\text { Estou grávida e me sinto bem. }\end{array}$ & $\begin{array}{l}\text { E.18 Uai, de todos foi normal né? Quando chegou nos } \\
\text { três deu poblema, perdi os dois meninos e a menina que } \\
\text { deu esse poblema de teto. Quando passou disso, com os } \\
\text { outros não correu risco em nada. Foi tudo normal, não } \\
\text { teve nada não. Eu tô grávida e tô sentindo bem. Não } \\
\text { sinto nada. [...] Quem fez meus partos foi essas } \\
\text { enfermeira que tem em Santa Maria, mesmo aí. } \\
\text { Mariinha de Maria Alves né? A que morreu também foi } \\
\text { essas meninas mesmo. }\end{array}$ \\
\hline $\begin{array}{l}\text { Os dois foram por meio de cesariana. O segundo foi } \\
\text { mais complicado: quase morreu dentro da minha } \\
\text { barriga. }\end{array}$ & $\begin{array}{l}\text { E.19 Uai é, o primeiro foi até tranqüilo né! O primeiro } \\
\text { que eu tive, mas o segundo num foi muito tranqüilo não, } \\
\text { porque foi mais complicado né? Que ele quaise morreu } \\
\text { dentro da minha barriga né? Ai, o meu é cesáreo, todos } \\
\text { os dois foi cesariana. }\end{array}$ \\
\hline
\end{tabular}

Em relação ao parto realizado em hospital e atendido por profissional de saúde, foram identificados os seguintes "discursos dos sujeitos coletivos":

1. Do que morreu, eu estava muito ruim, por isso tive de ir para o hospital. Tive eclampsia. Ele não tinha problema nenhum. Eu estou impressionada até hoje com a morte desse meu filho.

2. O pré-natal e o parto foram com o mesmo médico. Não houve perigo, e o parto

foi normal. 
3. Os partos foram normais, porém a médica não cuidou dele direito. Aconteceu que Deus levou todas as duas.

4. O parto foi feito por médico, só que não me lembro do nome dele. Eu senti muitas dores, mas o parto foi normal.

5. Foi a enfermeira que fez o parto, só que eu não sei o nome dela. Eu ganhei todos os meus filhos no hospital, e os partos foram ótimos.

6. Os dois foram por meio de cesariana. O segundo foi mais complicado: quase morreu dentro da minha barriga.

Ao contrário das mulheres cujos partos foram atendidos por parteiras ou familiares, no caso dos partos hospitalares, percebemos que, embora as mulheres também façam menção à normalidade do parto, elas não sinalizam uma relação de vínculo com o profissional que a atendeu. Na maioria das vezes, nem lembram o nome desse profissional.

Para alguns autores como Dias (2002) e Domingues, Santos e Leal (2004), diante da presença do profissional médico durante o parto, símbolo do poder, cientificidade e alívio da dor, a parturiente assume passiva e incondicionalmente o papel de paciente, submetendo-se às condutas oferecidas por profissionais cuja prática se baseia na crescente especialização e incorporação acrítica de tecnologias. Desse modo, retiram a capacidade da mulher de ser sujeito ativo do processo, distanciando-se cada vez mais da concepção de nascimento como um processo fisiológico e sociocultural, como ocorre quando o parto é realizado por parteira em domicílio.

Observamos a ausência de fala, por meio da qual ficasse implícito o recebimento de alguma orientação quanto aos cuidados a ser ministrados à criança no domicílio, ou que a mãe viesse a procurar ou receber a atenção dos profissionais da rede básica de saúde durante o puerpério. 
Desenvolvimento do Instrumento de Análise de Discurso - 2 (IAD-2)

2 Desenvolvimento do Instrumento de Análise de Discurso - 2 (IAD-2)

O que foi feito durante as gravidezes para que senhora e seus bebês não tivessem problema?

\section{A Gravidez sem acompanhamento de pré-natal}

\begin{tabular}{|c|c|}
\hline Idéia central & Expressões-chave \\
\hline $\begin{array}{l}\text { Eu nunca fiz pré-natal de nenhum deles. A dificuldade } \\
\text { é por causa da distância e das nossas condições. }\end{array}$ & $\begin{array}{l}\text { E.1 Uai, eu protegia igual eu protegia os outros tudo, } \\
\text { né? Eu nasci pra trabalhar; trabalhava mesmo, assim } \\
\text { direto. Quase não consultava porque é muito difícil. } \\
\text { Nunca fiz pré-natal de nenhum deles. [...] A } \\
\text { dificuldade é por causa de condições, né? que é muito } \\
\text { difícil. Ademais que o lugar mais perto é Carbonita e } \\
\text { Diamantina né, e pra gente que é pobre fica difícil. }\end{array}$ \\
\hline $\begin{array}{l}\text { Eu só fiz uma consulta e não cheguei a tomar nenhuma } \\
\text { vacina. A distância até o posto de saúde é muito } \\
\text { grande e não há condução. }\end{array}$ & $\begin{array}{l}\text { E.4 [...] da segunda eu só fiz uma consulta, né? Eu } \\
\text { num cheguei a tomá nenhuma vacina. O posto é em } \\
\text { Joanésia. A gente vai de a pé, né? Treis hora de } \\
\text { viagem. Um lugar longe. Num tem condução pra } \\
\text { gente ir lá pro enquanto. }\end{array}$ \\
\hline $\begin{array}{l}\text { Eu fui saber de pré-natal este ano. Quando fui tomar } \\
\text { vacina, disseram que eu não precisava. }\end{array}$ & $\begin{array}{l}\text { E.5 O que eu fiz foi limpação de roça. Foi. Se eu num } \\
\text { quetasse quase na hora, eu tava aí trabalhando na } \\
\text { roça. [...] Já vi falá de pré-natal, mas foi esse ano } \\
\text { agora (risos). [...] Ué, eu fui lá pra tomá vacina. Cabô } \\
\text { que as mulhé disse lá que num era pra eu tomá. }\end{array}$ \\
\hline $\begin{array}{l}\text { Lá no posto, eles aplicaram a vacina conforme está } \\
\text { marcado no cartão. Ir ao posto de saúde é muito difícil } \\
\text { e ele sempre está muito cheio. Eu ficava pensando: } \\
\text { "Vai chegar a hora de eu ganhar esta menina e eu não } \\
\text { fiz nem uma consulta". }\end{array}$ & $\begin{array}{l}\text { E.6 Se ele deu vacina lá? Deu e deu os coisa, os } \\
\text { cartão. Conforme tá marcado no cartão. Eu acho que } \\
\text { tem o cartão dela }{ }^{(1)} \text {. Meu eles num deram não.. Eles } \\
\text { num falô não. Tem vez que a gente vai no ônibus que } \\
\text { faz a linha. Dá um trabalho. Lá é muito difícil. Tem } \\
\text { vez que vai e dá trabalho. [...] Quando chegava lá } \\
\text { tava tudo cheio. Aí, meu Deus, vai chega ao ponto } \\
\text { deu ganhá esta menina, e eu num fiz nem uma } \\
\text { consulta. }\end{array}$ \\
\hline $\begin{array}{l}\text { Eu não tomei vacina porque eu tinha medo de agulha. } \\
\text { Agora é que resolvi tomar. }\end{array}$ & $\begin{array}{l}\text { E.7 Como eu ia falando, dos primeiros menino que é } \\
\text { o mais velho, e o outro segundo que é o que morreu, } \\
\text { dessas eu num tomei não. Dai pra cá é que lá no } \\
\text { hospital que a médica falô: Agora você passa, que } \\
\text { você num tomô as vacinas não. Aí eu falei assim: Não } \\
\text { poquê eu tinha medo de agulha. [...] Como de fato } \\
\text { tem esse cartão aqui, eu estou retornando com a } \\
\text { vacina de novo. }{ }^{(2)}\end{array}$ \\
\hline $\begin{array}{l}\text { Eu não fiz pré-natal da criança que morreu. Era muito } \\
\text { difícil para nós aqui da roça. Eu apenas tomei a vacina, } \\
\text { mas não me lembro pra que era. }\end{array}$ & $\begin{array}{l}\text { E.9 Desse eu fiz o pré, do outro não. Que era na roça, } \\
\text { né? Que era muito difícil, né? E dinheiro era muito } \\
\text { difícil também. Pra nós pôde ir. Num fiz não. O que } \\
\text { eu tomei foi as vacina só. }{ }^{(2)} \text { Lá em casa era muito } \\
\text { difícil. Num alembro pra quê que era as vacina não. } \\
\text { [...] Eles também num falô pra quê que era a vacina } \\
\text { não. }\end{array}$ \\
\hline
\end{tabular}




\begin{tabular}{|c|c|}
\hline Idéia central & Expressões-chave \\
\hline $\begin{array}{l}\text { Eu ia ao médico pra ver se o neném estava bem. Do } \\
\text { que morreu eu não tomei vacina. Eles falaram que não } \\
\text { precisava. }\end{array}$ & $\begin{array}{l}\text { E.11 Não. No caso dele num aconteceu nada não. } \\
\text { Tava lá beleza. [...] Só que dele eu num tomei as } \\
\text { vacina não. Que eles falô que num precisava. Que eu } \\
\text { tinha tomado da primeira (3). Que dele eu num } \\
\text { precisava tomá não. Aí, eu num tomei não. Só ficava } \\
\text { indo no médico pra vê como é que tava o neném e } \\
\text { tudo. Pra vê se tava ótimo, né? }\end{array}$ \\
\hline $\begin{array}{l}\text { Eu não quis fazer o pré-natal da criança. Mas tomei as } \\
\text { vacinas. }\end{array}$ & $\begin{array}{l}\text { E.12 Eu fiquei grávida logo, logo. Mas eu num quis, } \\
\text { eu num quis fazê o pré-natal da criança, né? Aí, a } \\
\text { criança assim nasceu doente, viu?[...] Dele eu tomei. } \\
\text { O cartão tá lá em casa. }{ }^{(4)} \text { O cartãozinho que eu } \\
\text { tomava, que eu tomo valcina, tá lá em casa. O cartão } \\
\text { deles também. Tá tudo lá em casa também. }\end{array}$ \\
\hline $\begin{array}{l}\text { Eu só fiz o pré-natal de um. Não foi do que morreu. Eu } \\
\text { tomei as vacinas, mas me esqueci para que servem. }\end{array}$ & $\begin{array}{l}\text { E.13 O pré-natal eu só fiz de um só. Eu valcinava. } \\
\text { Todo mês eu valcinava }{ }^{(4)} \text {. [...] Eu inté esqueci que } \\
\text { doença que ela falô, da doença que com a gente } \\
\text { valcina, pra gente vaciná, pra quando a gente tá } \\
\text { esperando, pra num pegá no menino, de doença. }\end{array}$ \\
\hline $\begin{array}{l}\text { Eu cuidei de mim direitinho, mas antigamente aqui não } \\
\text { havia vacina. Só recentemente tomei vacina. }\end{array}$ & $\begin{array}{l}\text { E.14 Eu fiz o que deve fazer, né? Eu fiz assim... Eu } \\
\text { alimentava bastante e cuidava direitinho. Mas, aqui } \\
\text { de primeiro não tinha esse negócio de vacina, né? } \\
\text { Esses três menino meu, desses quatro menino meu, de } \\
\text { nenhum eu tomei vacina. Só desse aqui pra cá é que } \\
\text { eu vim tomá vacina. }\end{array}$ \\
\hline $\begin{array}{l}\text { Somente fiz pré-natal das que nasceram no hospital, } \\
\text { mas não me orientaram. Eu não consultei quando tive } \\
\text { esse que morreu, nem tomei vacina nenhuma vez, } \\
\text { porque eu morava na roça. }\end{array}$ & $\begin{array}{l}\text { E.17 Tive acompanhamento do médico das que } \\
\text { nasceu no hospital. [...] Eu cheguei no hospital, soube } \\
\text { me cuidar direitinho e todo mundo olhando } \\
\text { direitinho, não teve problema não. Durante as } \\
\text { consulta também foi, eu consegui bom também. Não } \\
\text { falou nada pra mim não sobe como cuidar do imbigo, } \\
\text { não ensinou nada pra mim não. [...] Do que morreu } \\
\text { não fiz consulta nenhuma porque eu tava na roça, lá } \\
\text { perto de Garapoavas. As vacinas foi tudo bom } \\
\text { também. De dois eu tomei, que foi desse aqui e dessa } \\
\text { outra ai. }{ }^{(I)} \text { Só que eu não lembro assim, eu não } \\
\text { lembro não. Uma foi contra o tétano e as outras eu } \\
\text { não lembro não. }\end{array}$ \\
\hline $\begin{array}{l}\text { A gente passava muita dificuldade nessa época, por } \\
\text { isso eu não fazia pré-natal. Quando tive esse menino } \\
\text { que morreu, não tomei nenhuma vacina, mas elas é que } \\
\text { são culpadas porque não passaram. }\end{array}$ & $\begin{array}{l}\text { E.18 [...] a gente passava muita dificuldade, né? Nóis } \\
\text { passava muita dificuldade nesse tempo. [...] Do } \\
\text { menino eu acho que não tomei nenhuma vacina. [...] } \\
\text { Mas elas lá é que é culpada, não é eu, né? Se elas } \\
\text { não passo valcina, como é que eu ia toma, né? }\end{array}$ \\
\hline
\end{tabular}

(1) Registro de apenas 1 dose de dupla (2) Registro de 2 dose de dupla posterior ao óbito

(3) Não havia registro em cartão de vacina (4) Registro de 3 doses de dupla 
Das idéias centrais agrupadas, resultantes das falas muito heterogêneas das mulheres que compõem o grupo que não teve acompanhamento de pré-natal, obtivemos os seguintes "discursos dos sujeitos coletivos":

1. Eu nunca fiz pré-natal de nenhum dos meus filhos. Não tomei nenhuma vacina. A dificuldade é por causa da distância e das nossas condições. Para gente que é pobre, fica muito difícil se deslocar, mas eu cuidava muito bem de mim.

2. Eu não fazia pré-natal porque passava muita dificuldade nessa época. Do menino que morreu, não tomei nenhuma vacina, mas elas lá do posto é que são culpadas porque não passaram.

3. Eu fui saber de pré-natal este ano. Na gravidez do meu filho que morreu, quando fui tomar vacina, disseram que não precisava. Eu trabalhava na roça até na hora de ganhar a criança.

4. Eu não tomei vacina porque eu tinha medo de agulha. Antigamente aqui não havia vacina. Só recentemente é que comecei a tomar, inclusive estou com o retorno marcado.

5. Eu ia ao médico para ver se o neném estava bem. Do que morreu, eu não tomei vacina. Disseram que eu não precisava tomar. Eu me esqueci para que serve a vacina.

6. Eu só fiz uma consulta e não cheguei a tomar nenhuma vacina. A distância até o posto de saúde é muito grande e não há condução.

7. Eu não quis fazer o pré-natal da criança. Mas tomei as vacinas.

A dificuldade de deslocamento por causa da distância e a falta de recursos é apontada pelas mulheres como a razão principal da ausência ao pré-natal. Existem mulheres que optaram por não fazer o pré-natal e outras que conheceram essa atividade recentemente. Há também mulheres que dizem não ter tomado a vacina por terem medo de agulha. 
Embora as condições socioeconômicas constituam fator determinante no processo de decisão atribuída pelas mulheres do estudo quanto à procura da assistência do pré-natal, estudos anteriores demonstram a importância do acesso e da qualidade da assistência na melhoria dos principais indicadores de saúde do País, mesmo nos momentos de crise econômica, desemprego ou subemprego, acompanhados de inadequadas condições ambientais e de moradia de grande parcela da população (MONTEIRO et al, 2000a; MONTEIRO et al, 2000b).

Segundo Bessa e Ferreira (1999), a escassez de recursos, a dificuldade de acesso e de transporte e a própria falta de atendimento nos serviços de saúde fazem com que as próprias parteiras, mesmo que saibam da necessidade de encaminhar a parturiente ao prénatal, não fazem essa orientação, porque acreditam que as gestantes não querem e não procuram outro tipo de atendimento. Até que ponto as parteiras sensibilizam suas "clientes" na busca de procedimentos mais adequados e até que ponto as "clientes" acreditam no “novo", uma vez que estão ancoradas nas opiniões dos familiares? Esses são questionamentos que merecem um estudo mais detalhado para que haja intervenções.

Os serviços de saúde no Brasil concentram-se nas capitais, nas áreas urbanas e nas zonas centrais, em detrimento das zonas rurais, das áreas mais pobres e periféricas, onde a densidade populacional é menor, o que, aliado a outros fatores socioeconômicos e culturais, determina extrema desigualdade na distribuição e oferta dos serviços de saúde, cuja conseqüência maior é a dificuldade de acesso a eles (BUSS, 1993; VICTÓRA et al, 1994; CAMPOS; CARVALHO, 2000).

De acordo com Fekete (1995), numa compreensão mais ampla, a acessibilidade pode ser definida como o grau de ajuste entre as características dos recursos de saúde e as da população, no processo de busca e obtenção da saúde. 
Esse grupo de mulheres que não tiveram nenhuma inserção no pré-natal, embora faça menção à vacinação, parece desconhecer qual vacina é indicada nesse período e para que serve. Algumas mulheres, ao afirmarem que no próprio serviço de saúde foi dito que não precisariam tomar a vacina, sugerem existir oportunidades perdidas de vacinação (OPV).

$\mathrm{O}$ fato de algumas mulheres alegarem não ter tomado a vacina por falta de orientação e até por medo do procedimento deixa dúvidas quanto à veracidade dessa informação, pois é como se elas se eximissem da responsabilidade transferindo a culpa para o outro.

A transposição dessas representações para a prática do profissional de saúde poderia fazer com que os serviços contribuíssem mais efetivamente para a promoção da saúde da mulher. Além disso, essa contribuição talvez pudesse, de alguma forma, interferir nos processos formativos e educacionais em saúde.

\section{B Gravidez com acompanhamento de pré-natal}

\begin{tabular}{|c|c|}
\hline Idéia central & Expressões-chave \\
\hline $\begin{array}{l}\text { Eu consultava quase todo mês. Tomei uma dose de } \\
\text { vacina que aos oito meses a gente tem que tomar, mas } \\
\text { eu não sei se é a de tétano. Dizem que quando a pessoa } \\
\text { toma do primeiro não precisa mais tomar. }\end{array}$ & $\begin{array}{l}\text { E.2 Ah, as vacina, eu tomei uma vacina dele }{ }^{(2)} \text {. Que } \\
\text { com oito mês a gente tem que tomá, né? [...] Ah, eu } \\
\text { num sei não, num sei se é a de teto. [...] Dos outros } \\
\text { também eu não vacina, quando eu consultava eu não } \\
\text { tomava vacina deles não, porque diz que quando a } \\
\text { pessoa toma do primeiro, dos outros não precisa. A } \\
\text { médica que falou, né? [...] Quase todo mês eu num } \\
\text { passava sem consultar não. Consultava, a médica } \\
\text { olhava como é que tava, né? }\end{array}$ \\
\hline $\begin{array}{l}\text { O pré-natal correu bem; não deu anemia nem nada. Eu } \\
\text { tomei duas doses da vacina. }\end{array}$ & $\begin{array}{l}\text { E.3 As consulta, o pré-natal correu tudo bem. O } \\
\text { Doutor Joaquim fez [...] Fiz os exame que ele, ele } \\
\text { passou o pedido. [...] Num deu nenhum poblema, num } \\
\text { deu anemia nem nada. [...] Duas vacina passô, eu } \\
\text { tomei só duas. E da segunda eu tomei mais duas } \\
\text { também. }{ }^{(l)}\end{array}$ \\
\hline $\begin{array}{l}\text { Quando engravidei dela, não tomei vacina. Tomei a } \\
\text { vacina depois que eu a ganhei, porque o médico me } \\
\text { disse que ela é boa para o sangue. Consultei duas vezes } \\
\text { e peguei os papéis de encaminhamento para o hospital. }\end{array}$ & $\begin{array}{l}\text { E.8 [...] Eu tomei essa vacina, }{ }^{(I)} \text { porque diz ele que a } \\
\text { vacina é boa pro sangue, né? Mas, depois que eu } \\
\text { ganhei, mas depois que eu ganhei. Mas aí, quando eu } \\
\text { fiquei gorda dela eu num tomei vacina não. Eu fui } \\
\text { uma. Duas vezes. Foi com Doutô Valtair. [...] Peguei } \\
\text { meus papel pra que se precisasse eu ir pra Salinas, eu } \\
\text { já tava enviada pra ir, né? }\end{array}$ \\
\hline
\end{tabular}




\begin{tabular}{|c|c|}
\hline Idéia central & Expressões-chave \\
\hline $\begin{array}{l}\text { Fiz o pré-natal e consultava todo mês. Quando tive o } \\
\text { que morreu, não tinha tomado vacina. Só da última } \\
\text { gravidez, quando eu liguei, é que tomei a vacina. }\end{array}$ & $\begin{array}{l}\text { E10 Eu consultava todo mês, de todos eles. Eu só num } \\
\text { ia ganhá no hospital. [...]Só que desse que morreu, eu } \\
\text { não tomei vacina nenhuma. Nunca eu tinha tomado } \\
\text { vacina. Depois dessa derradeira que eu ganhei, e que } \\
\text { eu liguei, é que eu tomei vacina. Ai eles tomaram o } \\
\text { cartão lá, né? Pra olhá porque que foi que ele morreu } \\
\text { dessa doença. Que às vezes é pro causa que eu num } \\
\text { tinha tomado as vacinas, né? }\end{array}$ \\
\hline $\begin{array}{l}\text { Eu fiz o pré-natal em Conquista. Não me lembro de } \\
\text { que eles dessem nenhuma orientação. }\end{array}$ & $\begin{array}{l}\text { E.15 E no segundo, no, na terceira criança foi que eu } \\
\text { fui pra Conquista fazer o pré-natal }{ }^{(I)} \text { Fiz os dois pré- } \\
\text { natal em Conquista. [...] E aí, tava tudo bom, só que } \\
\text { no, nasceu normal a criança. Foi uma menina } \\
\text { moleca. Foi essa que aconteceu, que faleceu lá em } \\
\text { Conquista, nasceu normal, saudia. [...] Não, não } \\
\text { alembro que eles deram nenhuma orientação. }\end{array}$ \\
\hline $\begin{array}{l}\text { Fiz o pré-natal direitinho. Todos os meses eu fazia o } \\
\text { pré-natal. Tomava as vacinas direitinho, contra, } \\
\text { principalmente, tétano umbilical. }\end{array}$ & $\begin{array}{l}\text { E.16 Ah, eu tomei as vacina como o médico me } \\
\text { orientou direitinho, procurava a alimentação assim } \\
\text { direitinho do jeito como ele me falou, não fazia muito } \\
\text { esforço, procurava repousar mais, ai Graças a Deus } \\
\text { não teve erro nenhum. Fiz pré-natal direitinho } \\
\text { conforme o médico me orientou e ai náo teve } \\
\text { problema nenhum.Ah, todos os meses eu fazia o pré- } \\
\text { natal quando o médico marcava pra mim. Eu tomava } \\
\text { toda a vacinação direitinho }{ }^{(1)} \text {. Contra principalmente } \\
\text { pro tétano no umbigo, né? Acho que } 3 \text { doses que eu } \\
\text { tomei. }\end{array}$ \\
\hline $\begin{array}{l}\text { Eu fiz o pré-natal de todos. Todo mês eu ia consultar. } \\
\text { Eu não me lembro quando começou. }\end{array}$ & $\begin{array}{l}\text { E.19 Fui acompanhada pelo Doutor Saulo. Inclusive } \\
\text { esse último meu que eu tive, que eu perdi ele }{ }^{(3)} \text {. Ele } \\
\text { revi, ele virava na minha barriga assim... Ele virava. } \\
\text { Aí, eu falava pra assim: Doutor Saulo num tem que } \\
\text { fazê é a ultra-som não, pra vê como é que o neném } \\
\text { tá? Aí, ele falava: O neném tá bem, num precisa } \\
\text { preocupá não. E ele ainda perguntava se eu fumava, } \\
\text { se eu bebia. Eu assim não. Eu num fumo. Eu num } \\
\text { bebo. Eu fiz todos os dois foi com o Doutor Saulo. } \\
\text { Todos os dois foi com ele. Todo mês. Todo mês que eu } \\
\text { ia. Todo mês. Eu num tô lembrada quando começô } \\
\text { não. Num tô lembrada não. }\end{array}$ \\
\hline
\end{tabular}

(1) Não havia registro em cartão de vacina (2) Registro de apenas 1 dose de dupla (3) Registro de 2 doses de dupla

Em relação a essa modalidade, mulheres que compõem o grupo que teve acompanhamento pré-natal, foram identificados os seguintes "discursos dos sujeitos coletivos": 
1. Eu consultava quase todo mês. Não me lembro de quando começou e nem se deram orientação. Tomei uma dose da vacina que tem de tomar aos oito meses, mas eu não sei se é a de tétano. Dizem que quando a pessoa toma do primeiro não precisa tomar mais.

2. Consultei duas vezes, mas não me lembro de quando começou. Peguei meus papéis, pois se precisasse internar já estava encaminhada. Tomei a vacina depois do parto, porque o médico disse que ela é boa para o sangue.

3. Fiz o pré-natal direitinho. Todos os meses eu consultava. Não me lembro de quando começou. Tomava as vacinas direitinho, principalmente contra o tétano no umbigo.

Percebe-se, por parte das mulheres, falta de clareza e de compreensão quanto à importância do pré-natal, desconhecimento do mês de gestação em que deve ser iniciado, da periodicidade das consultas, das orientações sobre as vacinas, do número de doses, do tempo de validade para futuras gestações, bem como sua importância, dos cuidados com o recémnascido, do planejamento familiar e outros. De modo geral, as atividades e os procedimentos que envolvem o pré-natal ficam restritos ao ato da consulta médica.

Segundo Tanaka (1986), fatores ligados à instituição, entre eles a deficiência técnica ou numérica de profissionais, possuem peso tão forte que chega a anular os benefícios dos cuidados recebidos pela gestante durante o pré-natal.

Para a mulher no ciclo gravídico-puerperal, a assistência no pré-natal e a assistência no parto e no puerpério estão intimamente interligadas, e a falta de acesso às informações, de forma contínua e integral, em qualquer desses momentos, fragiliza a assistência, expondo a mulher e o recém-nascido a risco de morte.

Compreender que a saúde das pessoas e de uma comunidade não depende apenas das ações de saúde é fundamental, tanto por parte dos profissionais de saúde, como por parte da população. A saúde pode ser vista como um recurso para a vida diária, abrangendo os 
recursos sociais e pessoais, bem como as capacidades físicas dos indivíduos e da população. Desde que conte com os conhecimentos, a compreensão e a motivação necessárias, a própria população poderá refletir sobre a sua saúde, adotar medidas práticas para a sua manutenção ou melhoria, propor e realizar mudanças para a solução de seus problemas, de modo que as pessoas decidem se e quando usar o sistema de atenção à saúde (BRASIL, 1981; STARFIELD, 2002).

Parece que, na percepção das gestantes, manter algum vínculo com o pré-natal, independentemente da sua qualidade e da sua freqüência, garante o seu encaminhamento ao parto hospitalar. Nas camadas populares, é forte o simbolismo do papel assinado, principalmente por alguém que detém algum tipo de poder, no caso o médico. São mecanismos que os médicos utilizam para assegurar seu lugar nos serviços de saúde.

A humanização do parto e do nascimento, direito da gestante - o qual deveria ser o desfecho natural de um pré-natal bem conduzido -, pressupõe uma relação de respeito e solidariedade entre os profissionais e a parturiente. Essa relação envolve conhecimentos, habilidades e atitudes que permitem ao profissional garantir o bem-estar físico e emocional da mulher durante o ciclo gravídico-puerperal. 
Desenvolvimento do Instrumento de Análise de Discurso - 2 (IAD-2)

\section{(P3) Alguma das crianças morreu? Fala-me a respeito}

\begin{tabular}{|c|c|}
\hline Idéia central & Expressões-chave \\
\hline $\begin{array}{l}\text { Foi o meu último filho que morreu. Eles não me } \\
\text { disseram que ele morreu. Eu sofri muito com a morte } \\
\text { desse menino. }\end{array}$ & $\begin{array}{l}\text { E.1 Nenhum filho meu teve problema de saúde. Só o } \\
\text { último é que teve. O último que eu ganhei teve. Não sei } \\
\text { porque ele ficou passando mal e eu levei pra } \\
\text { Diamantina. Chegando lá ele morreu, e eu vim embora } \\
\text { pra cá e eu não sei o quê que deu. Não fiquei sabendo o } \\
\text { que deu, ele ficou lá } 4 \text { dias. [...] Depois de assim uns } 4 \\
\text { dias que eu ganhei ele, ele começou a passar mal. Só } \\
\text { que quando eu tava esperando ele, me deu uma tosse } \\
\text { ruim, que eu tossi demais. Tossi mesmo. [...] Ah, ele } \\
\text { chorava, espirrava, acabava chorando, parecendo que } \\
\text { ele ia acabar e eu corri com ele pra Diamantina, } \\
\text { Carbonita, depois eles mandou pra lá. Eles não falou o } \\
\text { que ele teve não. Ninguém falou não, porque não deu } \\
\text { tempo, né? Eles ficaram fazendo exames nele lá. Depois } \\
\text { ele faleceu, e eu vim embora. Ai eu não fiquei sabendo } \\
\text { não. [...] Eu sofri totalmente a morte desse menino. }\end{array}$ \\
\hline $\begin{array}{l}\text { Eu não sei por que deu problema no umbigo do } \\
\text { menino. Eles dizem que foi tétano. Depois que a } \\
\text { mulher cuidou do umbigo do menino, ele só foi } \\
\text { piorando. }\end{array}$ & $\begin{array}{l}\text { E.2 [...] eu num sei por causa de quê que deu poblema } \\
\text { no, no imbigo desse menino, deu, deu teto, né? Igual } \\
\text { eles fala. Aí, despois que ela, que ela mexeu no imbigo } \\
\text { do menino, o menino não quiz mamar mais.[...] Foi a } \\
\text { mulher colocar a mão, colo, me, mexeu com o imbigo } \\
\text { do menino, o menino cabou, parou de, de mamar, só } \\
\text { vivava, só a mul..., três dia, três dia que ele sofreu, cho, } \\
\text { chorando. Sabe? [...]Eles fala que é tétano, né? Eu } \\
\text { mesmo expliquei, que eles fala. Que eu fiquei boba } \\
\text { como que assim que ela curou, que ela mexeu no imbigo } \\
\text { do menino, o menino não quis mamar mais. [...] Ele foi } \\
\text { pro Siderúrgica. Lá..... E pra falar a verdade ele ficou } \\
\text { foi no isolamento, né? Isolamento por causa de que., } \\
\text { que.. Que eu mesmo fiquei tão ruim daquele menino, } \\
\text { fiquei tão ruim, que, que eu nem fui acompanhá o } \\
\text { menino não, de tão ruim que eu fiquei. }\end{array}$ \\
\hline $\begin{array}{l}\text { Minha filha ficou em casa chorando uns dez dias. No } \\
\text { hospital, disseram que era tétano. Só que eu não } \\
\text { acredito que foi tétano que a matou. }\end{array}$ & $\begin{array}{l}\text { E.3 [...] É, eu cheguei em casa e ela ficô em casa uns } \\
\text { dez dias em casa. Aí ela ficô uns dez dias em casa } \\
\text { chorando. Ai teve um dia que ela chorô a noite intera. } \\
\text { [...] Ai eu levei ela pro Márcio Cunha. No Márcio Cunha } \\
\text { fiquemos uns dois meses com ela lá. Tomando conta } \\
\text { dela no Márcio Cunha lá e eles olhando ela. Eles } \\
\text { falaram que é teto. Aí num teve jeito com ela não. E ela } \\
\text { morreu. Só que eu num acredito que isso é teto que } \\
\text { matou ela não. Ela já saiu, eu acho que ela já saiu do } \\
\text { hospital foi doente. Que eu num tive nem um dia de } \\
\text { prazer com ela em casa. }\end{array}$ \\
\hline
\end{tabular}




\begin{tabular}{|c|c|}
\hline Idéia central & Expressões-chave \\
\hline $\begin{array}{l}\text { Minha filha teve tétano no umbigo. Nós pensamos } \\
\text { que era dor de barriga, mas no hospital eles disseram } \\
\text { que era tétano no umbigo. }\end{array}$ & $\begin{array}{l}\text { E.4 [...] E a segunda deu teto no imbigo. A Letícia só, só } \\
\text { doze dias que ela teve comigo. Aí, ela teve internada no } \\
\text { Márcio Cunha. Veio pra cá e fazendo oito dias ela } \\
\text { faleceu. Aconteceu que ela assim passô mal, né! E a } \\
\text { gente levô ela pro hospital e chegô lá os médico falô } \\
\text { que ela tinha dado teto no imbigo. Não, eu observei né } \\
\text { que ela amanheceu assim... Que ela chorô a noite toda. } \\
\text { Quando foi de manhã ela assim deu sinal de ficá mais } \\
\text { ruim. A gente pensô que era uma dor de barriga, né! } \\
\text { Levô na farmácia, aí chegô lá eles mandaram remetê } \\
\text { com ela, com ela pro hospital. Aí, chegô no hospital eles } \\
\text { falaram que era teto no imbigo. No Márcio Cunha. Lá } \\
\text { no hospital o atendimento foi muito ótimo. Eu fiquei lá } \\
\text { foi só oito, só oito dias, né! Que eu tinha a outra e a } \\
\text { outra tava chorando pro minha causa. Aí, eu vim } \\
\text { embora e a, ela ficô lá só no hospital. Porque num } \\
\text { dependia de mim, porque ela tava na incubadora lá e } \\
\text { toda cheia de aparelho. Então não dependia de mim, } \\
\text { né? Aí, os médico me libero pra eu vim pra casa. [...] Só } \\
\text { que eu num tenho nenhuma comigo. Deus levo todas as } \\
\text { duas. }\end{array}$ \\
\hline $\begin{array}{l}\text { Dois morreram com o mal-de-sete-dias. Eles ficaram } \\
\text { com a carne dura. }\end{array}$ & $\begin{array}{l}\text { E.5 Morreu. Essa que morreu e o outro também que } \\
\text { morreu. Foi do mal-de-sete-dia também. Tem dois e } \\
\text { quatro ano agora. Eles doeceram é porque eles fica... A } \\
\text { carne deles fica dura assim... Com três dia adoeceu e } \\
\text { num aduraram os quatro dia, e só. Com uns três dia } \\
\text { arruinô. O outro também foi. }\end{array}$ \\
\hline $\begin{array}{l}\text { A menina morreu com "male". A gente conhece } \\
\text { quando um filho adoece. }\end{array}$ & $\begin{array}{l}\text { E.6 [...] Uai, a menininha eles disse que foi... A } \\
\text { menininha morreu com male. Não, até que não. Ela } \\
\text { começô a arruinar e logo nóis levô ela pra lá. Nóis levô } \\
\text { ela pra São João da Ponte e em São João da Ponte eles } \\
\text { deram a ficha pra nóis levá ela pra Montes Claros. Ela } \\
\text { mamava muito pouco. Uai, pro causa que a gente } \\
\text { conhece, pro causa que a doença, que de primeiro é na } \\
\text { hora que começa. Ela pegava no peicho, mas dava } \\
\text { trabalho pra pegá. Os outro tudo mamô no peicho. }\end{array}$ \\
\hline
\end{tabular}




\begin{tabular}{|c|c|}
\hline Idéia central & Expressões-chave \\
\hline $\begin{array}{l}\text { Meu filho adoeceu, e acho que isso me atacou muito a } \\
\text { cabeça. Eles me disseram que meu filho teve tétano. }\end{array}$ & 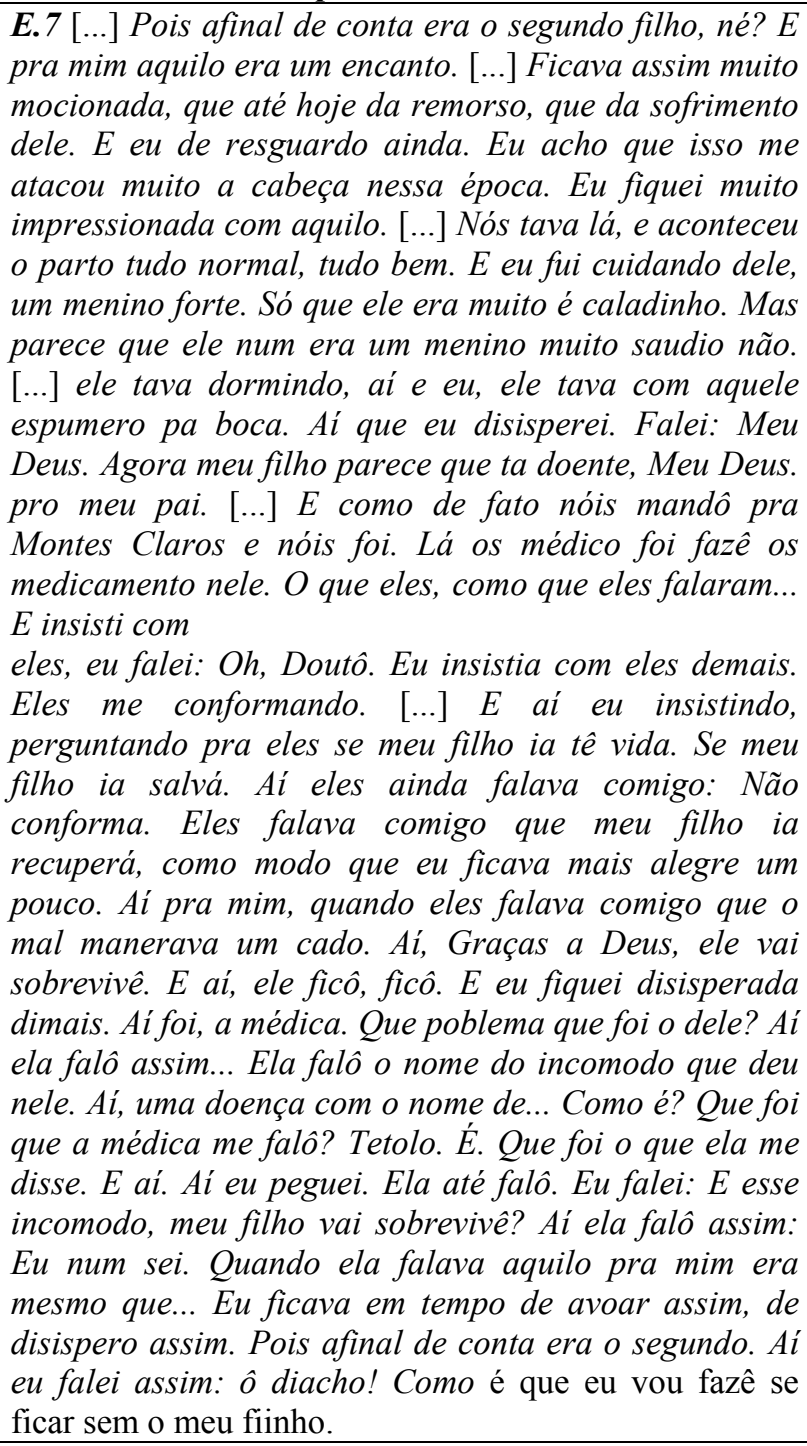 \\
\hline
\end{tabular}




\begin{tabular}{|c|c|}
\hline Idéia central & Expressões-chave \\
\hline $\begin{array}{l}\text { Eles me disseram que foi mal-de-sete-dias. Aqui, } \\
\text { disseram que ela morreu por causa da vacina. }\end{array}$ & $\begin{array}{l}\text { E.8 [...] E tem outro também que morreu novo, também. } \\
\text { [...] Eles falo pra mim que era mal, que era mal que } \\
\text { tinha dado na menina. Mas do jeitinho que ela era, a } \\
\text { menina adoeceu e de repente começô a manchar assim, } \\
\text { num instante. E ficava parada assim, e chegava a } \\
\text { espumar a boquinha. É. Muita gente falô que era mal- } \\
\text { de-sete-dia que deu, que começô a dá nela. [...]E uns } \\
\text { fala que é inté a vacina. E começô, ela começô a } \\
\text { adoecer depois que tomô a vacina. Com sete dia. E, foi } \\
\text { com sete dia que eu tinha ganhado ela. [...] Muita gente } \\
\text { falô que era a vacina. Eu num sei! Uns fala uma coisa, } \\
\text { outros fala outra, né? O povo todo aqui falô que foi a } \\
\text { vacina. Depois que a menina tomô a vacina, a menina } \\
\text { arruinô. [...] Desse dia em diante, ela num mamô mais } \\
\text { não. Assim inté com oito dia a menina era espertinha. } \\
\text { Tinha hora que, ela mesma punha a mãozinha dela na } \\
\text { boca assim, oh. Mamava a bichinha. De oito dia em } \\
\text { diante que ela num mamo mais, dispois que ela tomo } \\
\text { essa vacina. O povo fala que é a vacina que fez mal a } \\
\text { essa criança. Eu sei lá! [...]É. Eu fico pensando é isso. } \\
\text { Muitos deles falô. se não fosse a vacina, ela num tinha } \\
\text { morrido, num tinha adoecido. Ela tinha } \\
\text { hora que ela ficava paradinha assim, oh. Mas é... A } \\
\text { bichinha tinha hora que ela nem chorava. Eu acho que } \\
\text { era tanta dor que vinha nela. Ela chegava a ficá } \\
\text { parada, roxinha e depois com pouco voltava de novo. } \\
\text { Aí, eu levei ela pra Montes Claros também. Ela adoeceu } \\
\text { que nem hoje, e que nem amanhã e eu levei ela. Quase } \\
\text { que no mesmo dia parece. Foi no mesmo dia que eu } \\
\text { levei ela, que ela fico ruim. }\end{array}$ \\
\hline Meu filho morreu de mal de umbigo. & $\begin{array}{l}\text { E.9 Uai é, eu levei ele pra Minas Novas, pra fazê o } \\
\text { tratamento lá. Que num tava muito bem. Aí levei pra } \\
\text { tratá lá. Aí ele não conseguiu vivê. Morreu, né? É } \\
\text { porque esse aí, esse aí, num deu mal de umbigo, o outro } \\
\text { deu, né. Teve dificuldade de mamar. Até que chorá, num } \\
\text { chorava muito não. Ele ficava assim com, assim com a } \\
\text { boca trancada. Num conseguia mamar. }\end{array}$ \\
\hline
\end{tabular}




\begin{tabular}{|c|c|}
\hline Idéia central & Expressões-chave \\
\hline $\begin{array}{l}\text { Eles não disseram o nome da doença que meu filho } \\
\text { teve. Quando recebemos o atestado de óbito é que } \\
\text { ficamos sabendo que ele tinha morrido de tétano. }\end{array}$ & $\begin{array}{l}\text { E.10 [...] quando tava com uns quatro dias depois, eu } \\
\text { tava com ele assim no colo e ele pegou a esticar assim e } \\
\text { deu uma tremura. Aí eu falei assim: o neném tá sentindo } \\
\text { uma coisa. Num dormia de noite, e danava a chorar e } \\
\text { num mamou mais. Tava sentindo uma coisa. E aí ele } \\
\text { deu, deu a elevá a temperatura, e eu disse: essa criança } \\
\text { tá sofrendo um ataque. E dessa hora pra cá ele começô } \\
\text { a chorar. E ai arruínô mesmo. Aí levô pro hospital em } \\
\text { Taiobeiras e aí de lá eles mandô pra Montes Claros. } \\
{[\ldots] \text { Eles num falô que doença que era não. Depois, }} \\
\text { agora que o papel chegô, que falô que era teto } \\
\text { neonatal. Que chamava, né? Eles falava que era teto, } \\
\text { né? Mas num falava, né? [...] Até eles punha assim um } \\
\text { tanto de trem pra ele ficá no escuro. Pra ele diquiri } \\
\text { melhora, né? Mas ele não diquiriu melhora nenhuma } \\
\text { não. De quando ele foi, ele foi inté que ele morreu. Só } \\
\text { sentindo assim, inculhidinho, inculhidinho, } \\
\text { inculhidinho. Num podia incostá nele. Batendo assim os } \\
\text { bracinhos assim... Só vendo. }\end{array}$ \\
\hline $\begin{array}{l}\text { A médica que nos atendeu disse que ele morreu por } \\
\text { falta de cuidado com o umbigo. Ela não disse o nome } \\
\text { da doença. }\end{array}$ & $\begin{array}{l}\text { E.11 [...]Eu sei que nós levamos ele pra Montes Claros, } \\
\text { e lá num teve jeito mais não. Colocô ele no balão de } \\
\text { oxigênio, né? Aí, num teve jeite. Quando foi umas oito } \\
\text { horas da manhã, eles ligô e falô que ele tinha morrido. } \\
\text { Aí, num teve jeite mais. Ele quando nasceu mamô só nos } \\
\text { sete dia. Depois que adoeceu ele num mamô mais não. } \\
\text { Assim mesmo mamava pouquinho. Ele chorava dimais. } \\
\text { Um tanto assim... Só o barriguinha dele que começô a } \\
\text { indurecer. Fez igual, ficô igual um pau assim... Duro } \\
\text { assim... E ele só chorando, chorando. [...] Eu sofri } \\
\text { dimais com ele, viu? Eles falô assim... Que, pro causa } \\
\text { que ele morreu... Foi a médica que tava, que olhô ele, } \\
\text { que atendeu ele, } \\
\text { né? E falô que foi falta de cuidado. Que cortô o umbigo } \\
\text { dele. O que colocô no umbigo. Que num cortô direite. } \\
\text { Que num queimô direite. Por isso que deu esse } \\
\text { poblema. O que ela me contô. Foi isso assim, a médica, } \\
\text { né? A doença num falô comigo não. Ela num me falô } \\
\text { que doença que era não. }\end{array}$ \\
\hline
\end{tabular}




\begin{tabular}{|c|c|}
\hline Idéia central & Expressões-chave \\
\hline $\begin{array}{l}\text { O médico disse que a criança teve "mal de umbigo". } \\
\text { Para mim o que a matou foi cólica. }\end{array}$ & $\begin{array}{l}\text { E.12 Ah! Diz que é mal, né? Do umbigo, né? Disse que } \\
\text { é. O médico falô que é mal do umbigo que teve a } \\
\text { criança. Ele diz que é. Num teve jeito! Cólica. Uma } \\
\text { cólica brava do umbigo, né? Num mamou não.[...]Ele } \\
\text { mamava pouquinho, mas a cólica num deixava ele } \\
\text { mamar não. Ele chorava bastante. Quando eu punha o } \\
\text { peito na boca dele. E aí, ele injeitava pra traz. Chega a } \\
\text { ficá branco, tava todo exitadinho. Os bracinhos dele } \\
\text { tava até gordinho. O que matô ele foi a cólica mesmo. }\end{array}$ \\
\hline $\begin{array}{l}\text { Depois de seis dias de nascido, ele adoeceu. Ele } \\
\text { morreu em casa e não deixaram que eu cuidasse dele. } \\
\text { Eles disseram que era o mal-de-sete-dias. }\end{array}$ & $\begin{array}{l}\text { E.13 [...] Que ele quase num mamava. Aí, quando interô } \\
\text { assim... Quando ia interá os sete dias, pra que ele ia } \\
\text { morrer, ele não quis mamar mais. De um dia pro outro, } \\
\text { né? Assim interô } 6 \text { dias, que nem hoje, amanhã ia intera } \\
\text { sete, né? Aí, que nem hoje, ele num mamô mais. } \\
\text { Amanheceu doente, né? E ficô uma noite assim, sem } \\
\text { mamar. Não tomó, num tomava mais nada. Acho que é } \\
\text { só. E ele ficava só chorando também. [...] Quando ele } \\
\text { ia, adoeceu pra morrer eu nem vi também. Ele ficava } \\
\text { dentro dum quarto pra lá, e eu ficava no outro quarto. } \\
\text { Minha tia não deixava eu nem ver! Ela não deixava eu } \\
\text { ver não. Ele ficava dentro do } \\
\text { quarto mais ela lá e eu ficava noutro quarto separado. } \\
\text { [...] Ele morreu em casa. Num levô pro hospital não. } \\
\text { Porque num dava tempo, né? E nesse tempo também } \\
\text { tava muito chovendo. Inté o mês de novembro. [...] Eles } \\
\text { fala assim que o menino doece: disse que é um mal que } \\
\text { dá. Que o mal-de-sete-dias. Num conheço outro caso } \\
\text { não. Num ouvi falá de tétano não. }\end{array}$ \\
\hline $\begin{array}{l}\text { Entre seis ou sete dias de nascido, ele adoeceu. O } \\
\text { médico disse que ele não sobreviveria porque estava } \\
\text { com mal-de-sete-dias. }\end{array}$ & $\begin{array}{l}\text { E.14 [...]logo ele foi nascendo, com seis dias ele } \\
\text { adoeceu, o umbigo dele caiu quando ele tava, ele tava } \\
\text { doente. Ah, ele começo assim: dia que ele fez seis dias, } \\
\text { né? Seis pra sete dias. Eu peguei ele e fui dá banho } \\
\text { nele. Quando eu peguei ele e fui pô ele dentro da } \\
\text { banheira de água, ele roxiou todinho, roxiou e } \\
\text { endureceu. Ficou durinho. [...] Chorô, chorô a noite } \\
\text { toda e num dormiu a noite um pingo. Ficou só } \\
\text { chorando. Toda vez dava aquelas coisas assim, ficava } \\
\text { durinho. Ficava pretinho. [...] Até nos seis dias pra cá } \\
\text { que ele não pegou mais no peito. Num conseguia } \\
\text { mamar mais. O doutor Joaquim mesmo, aí, no hospital } \\
\text { em Maxacalis, falou pra mim que podia trazê o menino } \\
\text { pra casa poque o menino num tinha jeito mais, né? } \\
\text { Porque era mal-de-sete-dias, que era. [...] Ai ele falou } \\
\text { assim, oh! Esse aqui vocês podem levar pra casa! Aí o } \\
\text { outro doutor chegou e falou que não, que era pra levar } \\
\text { ele pra Teófilo Otôni. Que lá, que ele ainda ia ser até } \\
\text { Presidente da República (risos). }\end{array}$ \\
\hline
\end{tabular}




\begin{tabular}{|l|}
\hline \multicolumn{1}{|c|}{ Idéia central } \\
\hline O médico me perguntou se eu tinha colocado alguma \\
coisa no umbigo da criança. Eu coloquei pena de \\
galinha e sola. Eles falaram que tinha dado tétano.
\end{tabular}

Ela morreu de parada cardíaca aos 18 dias. No hospital, eles não explicaram. Queimei os documentos da criança e parte dos meus.

O que morreu com tétano foi falta de responsabilidade da minha cunhada. Ela cortou o umbigo com uma faca. O médico disse que foi tétano no umbigo.

\section{Expressões-chave}

E.15 [...] Só que entre os dois dias, como eu tava acabando de acontê, de contar, aconteceu! Pra mim eu senti que ela tava sentindo uma dor, tá entendendo? Nos dois dias. Nos três dias eu fui pra Conquista de novo. Chegou lá, internô ela. Aí o médico de lá me perguntô, aliás uma médica me perguntô, se eu tinha colocado alguma coisa no imbigo da criança. Eu falei que tinha colocado. Foi o que eu disse pra eles. Eu falei: eu coloquei a pena de galinha e a sola. Ai foi na hora que eles falo que não podia tê colocado nem a pena de galinha, nem a sola. Aí eles falô que tinha dado tetro. [...]Ai ela ficou lá 9 dias, 9 dias. Em 10 dias ela faleceu. [...] Ela chorava, totalmente à noite, e a gente dormia assim: um muito se a gente dormisse era umas duas horas de relógio. [...] Nóis é muito feliz. E sô muito feliz pelos outros que tá lá entregue a Deus.

E.16 Com 18 dias de vida ela deu a parada cardíaca, $e$ ai nos, ai rapidinho, procurou recurso em Lafaiete e ai chegou lá ela foi dando infarte e chegamos a conclusão que ela deu e não voltou mais, foi isso. Lá no hospital eles num falaram o que a menina teve não. Até fez, sabe como é que fala, aquele negócio que tira os material sabe? Mas não mandou o resultado pra nós nenhum. Nós procurou mas disse que não tinha chegado ainda. Ah, eu fiquei muito aborrecida, sabe? Juntei e queimei tudo, cartão, certidão de nascimento, o cartão dela, o meu, eu queimei tudo. Ela num teve tétano porque o imbiguinho dela ficou sabe, normal, não teve problema nenhum.

E.17 Porque esse, o que morreu em (pausa), esse que tô falando que morreu de tétano, esse foi falta de responsabiliz da minha cunhada né? Que eu tava sozinha e na hora não tinha ninguém pra me levar no hospital e ai dia sim eu arrumei, que na hora eu desmaiei e aí ia dizendo os meus meninos que viu ela cortando com uma faca. Quando tava assim nos 7 dias ele começou a serrar o queixinho, eu levei pro hospital e de lá eu levei pra Brasília. Cê chega no hospital e diz o médico, o Dr. Agnaldo que foi, que tinha sido tétano, tinha dado tétano no imbigo dele.

O problema da criança foi tétano. A mulher não cuidou corretamente do umbigo. Colocou coisas estranhas nele. Eu não pude falar nada, porque não cuido de criança pequena..
E.18 Ela nasceu tudo bem! [...] Com sete dias não caiu não. Quando deu 8 dia, com 8 dia ela deu, deu poblema do teto. [...] A que cuidava dela tomava, pinga, sô sabe né? Pra cuidá da menina. Eu acho que ela não cuidou do modo que precisava cuidar, mas eu não podia falar nada, porque eu não cuido, entendeu? Eu tenho medo, tenho medo de olhá criança assim pequenininho. Aí, eu pedi ela pra olhá, mas ela não soube olhá direito e colocô as coisas de fora, né? Aí, ela foi deu esse poblema, e gritando, gritando. E eu não sabia o que era. Quando chegô lá em Santa Maria que eles olhô, ela já tinha dado um caroço nas costas dela. Aí, eles falô: não tem jeito mais não. O poblema dela é grave, né? Lá em Belo Horizonte talvez ela recupera. Chegô lá, não teve jeito, né? Tudo que pode eles fizeram. Não teve jeito, né? (choro). 


\begin{tabular}{|l|l|}
\hline \multicolumn{1}{|c|}{ Idéia central } & \multicolumn{1}{c|}{ Expressão-chave } \\
\hline $\begin{array}{l}\text { Ele morreu quando completou sete dias de nascido, } \\
\text { por causa do tétano e de problemas de coração. }\end{array}$ & $\begin{array}{l}\text { E.19 O segundo é o que morreu com teto né! Teto e } \\
\text { poblema de coração. Ué, a partir do dia que eu saí do } \\
\text { hospital. [...] Quando foi no domingo eu percebi que ele } \\
\text { num tava muito bom. Porque deu aquele negócio } \\
\text { amarelo. Aí, eu dei um banho nele no picão. Porque } \\
\text { eles fala sempre que o picão é bom pra melhorá. Aí, eu } \\
\text { dei banho nele no picão, que eles falá que tem que dá } \\
\text { banho uns treis dia e para que melhora, né! Aí, nós ficô. } \\
\text { E eu dei banho nele no domingo. Quando foi na } \\
\text { segunda-feira ele fez sete dia. Foi no dia que ele fez sete } \\
\text { dia que ele morreu. Depois de tarde que eu vi que ele } \\
\text { num tava bom. Ele num queria mamá, sabe? Eu dei } \\
\text { mamá no peito e ele num quis pegá o meu peito. Ai, eu } \\
\text { peguei ele e nós levamos ele no hospital. Aí, o Doutor } \\
\text { Márcio tava lá. Aí, o Doutor Márcio atendeu ele e levô, } \\
\text { encaminhố já pra Araxá. Aí, nós foi. }\end{array}$ \\
\hline
\end{tabular}

Das idéias centrais agrupadas, resultantes das falas muito heterogêneas das mulheres que compõem o grupo, em relação à criança que veio a óbito por tétano neonatal, obtivemos os seguintes "discursos dos sujeitos coletivos":

1. Foi o meu último filho que morreu; os outros não tiveram problema de saúde. Não sei por que ele ficou passando mal. Eles não me disseram e eu não fiquei sabendo do que ele morreu.

2. Deu problema no umbigo do menino. Foi tétano. Depois que a mulher cuidou do umbigo do menino, ele só foi piorando. Eu mesma fiquei boba como ela cuidou do umbigo e acabei ficando tão ruim que não acompanhei o tratamento dele.

3. No hospital, disseram que era tétano. Só que eu não acredito que foi tétano que a matou. Eu acho que ela já saiu do hospital doente. Não tive nem um dia de prazer com ela em casa.

4. Pensamos que era dor de barriga, mas no hospital eles disseram que era tétano no umbigo. Como não dependia de mim, os médicos me liberaram para vir para casa cuidar de minha outra filha. Só que Deus levou as duas. 
5. Os dois adoeceram porque ficaram com a "carne dura". Morreu com "male". Eles morreram foi pelo mal-de-sete-dias. A gente conhece quando um filho começa a adoecer. Eu ficava muito emocionada, e até hoje me dá muito remorso por causa do sofrimento deles.

6. Meu filho adoeceu, e eu acho que isso me atacou muito a cabeça. Eles me disseram que meu filho teve tétano, mas não me explicaram. Eles me disseram que foi malde-sete-dias. Aqui, disseram que ela morreu por causa da vacina. Eu tenho minhas dúvidas se realmente foi por causa da vacina.

7. A médica que nos atendeu disse que ele morreu por falta de cuidado com o umbigo. "Mal de umbigo". Ela não disse de que doença foi. Para mim, o que o matou foi a cólica. Uma cólica brava que não o deixava mamar. Sofri muito com ele.

8. Aos seis dias de nascido ele adoeceu. Ele morreu em casa, mas não deixaram que eu cuidasse e nem me aproximasse dele. Eles disseram que ele teve o mal-de-sete-dias.

9. Entre seis ou sete dias ele adoeceu. Um médico disse que ele não sobreviveria, porque era mal-de-sete-dias. Outro disse que ele ainda seria Presidente da República.

10. O médico me perguntou se eu tinha colocado alguma coisa no umbigo da criança. Eu disse que havia colocado pena de galinha e sola. Então ele disse que tinha dado tétano.

11. Ela morreu de parada cardíaca com enfarte. Lá no hospital eles não explicaram de que ela morreu. Para mim, ela não teve tétano, porque o umbigo dela ficou normal, não teve problema nenhum. Eu juntei e queimei os documentos da criança e parte dos meus.

12. O que morreu de tétano foi falta de responsabilidade da minha cunhada, que não cuidou corretamente dele. Colocou coisas estranhas no umbigo da criança. Meus filhos disseram que ela cortou o umbigo com uma faca. Eu não pude falar nada, porque não cuido. Tenho medo de cuidar de criança pequena. O médico disse que foi tétano no umbigo. 
A expressão "mal-de-sete-dias" ou simplesmente mal ou "male" ainda está presente em Minas Gerais, principalmente na zona rural. As mulheres atribuem a sua ocorrência ao fato de a criança até o sétimo dia ficar desprotegida do vento e da claridade. Em alguns casos, os contatos da mãe com a criança limitam-se aos momentos da amamentação, preconizando-se até mesmo a necessidade de que ela também evite o contato com a parte externa da casa, procedimento preservado por regiões em que há pessoas que ainda acreditam ser importante o período determinado como resgardo. ${ }^{7}$ Algumas mães correlacionam mal-desete-dias ao tétano umbilical; outras não fazem essa correlação.

Conhecimentos relativos ao saber popular com respeito a essa doença aparecem de forma significativa nas representações contidas nos depoimentos das mães, o que Boltanski (1984) denomina de "medicina dos não-médicos”, isto é, ações empreendidas com o fim de curar (cumprir o resguardo, tomar um chá), atos comuns referentes à presença do mal (verificar a temperatura) e diagnósticos empíricos baseados na lógica do "senso comum" (mal-de-sete-dias).

Mesmo que o profissional de saúde tenha feito referência ao diagnóstico de tétano ou tétano umbilical, percebe-se que os sujeitos demonstram desconhecer a doença, embora para algumas mães tenha chegado a informação de que a causa do óbito foi o tétano. Algumas mães conseguem descrever os sinais ou sintomas relacionados com a doença, mesmo que não conheçam a sua terminologia correta, e outras relacionam a doença aos cuidados com o umbigo.

Entre os direitos do paciente se inclui o de receber informações claras, simples e compreensivas, adaptadas à sua condição cultural, sobre as ações diagnósticas e terapêuticas,

\footnotetext{
7 Segundo Ferreira (1999) é o ato ou efeito de resguardar-se. Cuidado, precaução, prudência. Período subseqüente ao parto, em que a mulher observa certos cuidados, repouso, etc.
} 
das quais podem decorrer a duração do tratamento, a localização de sua patologia, bem como quais as regiões do corpo serão afetadas pelos procedimentos.

As reações de sofrimento, de inconformismo e até de revolta pela perda da criança estão presentes, embora em alguns casos já tenha se passado algum tempo. Mas há mães que demonstram certo conformismo pelo fato de Deus ter levado a criança para junto de si. Minayo (apud DIAS, 2002) afirma que o fenômeno religioso exerce a função de facilitar às pessoas em situações-limite a aceitar os desígnios de Deus.

Embora possam estar habilitados tecnicamente para o enfrentamento dessa doença, observa-se pouco ou total despreparo dos profissionais de saúde para lidar com os sentimentos e necessidades das famílias, principalmente nos momentos de perda.

\section{Desenvolvimento do Instrumento de Análise de Discurso - 2 (IAD-2)}

\section{(P4) O que a senhora fazia com o umbigo de seus bebês?}

\begin{tabular}{|c|c|}
\hline Idéia central & Expressões-chave \\
\hline $\begin{array}{l}\text { A minha mãe cortava o cordão umbilical com uma } \\
\text { tesourinha e amarrava. Depois colocava rapé feito com } \\
\text { fumo picado e batido. Notei apenas que ele estava } \\
\text { chorando muito. }\end{array}$ & $\begin{array}{l}\text { E.1 Aqui na roça minha mãe cortava assim com uma } \\
\text { tesourinha e amarrava. Era isso, cuidava né, e depois } \\
\text { colocava em volta o rapé assim, que fazia de fumo } \\
\text { picado e batido no pano. O último também foi com } \\
\text { rapé. Não notei nada no umbigo, achei que podia ser } \\
\text { por causa que ele tava chorando muito, né? Eu vou } \\
\text { levar porque eu não sei o quê... }\end{array}$ \\
\hline
\end{tabular}




\begin{tabular}{|l|}
\hline Idéia central \\
\hline O problema surgiu porque a menina que começou a \\
cuidar do umbigo não voltou para continuar. Eu não \\
cuido porque tenho medo de dar problema. Há \\
momentos em que fico até pensando como isso foi \\
acontecer.
\end{tabular}

1. Foi cuidado com arruda e pena de galinha. As enfermeiras do hospital orientaram direitinho, mas, quando chegamos em casa, uma mulher acostumada a cuidar de outro modo já havia preparado tudo. Foi cuidado com arruda e pena de galinha.

Foi cuidado com álcool absoluto. As enfermeiras me orientaram, e eu que cuidava do umbigo. Minha mãe só dava o banho.

A mesma mulher que cortou o umbigo também cuidou dele. Aqui, todos usam caroço de andu e raspa de chifre.

\section{Expressões-chave}

E.2 [...] Desde dessa vez, desde dessa vez, que, que essa menina mexeu com o imbigo do menino, que ela não, que ela não voltou pra, pra acabar de curar, né? [...] minha mãe, quando ela era viva, ela é que curou o imbigo dessa, dessa, desse de doze anos, a outra que vai fazer seis anos, seis anos. E a outra que ta lá na creche, de 4 anos. E esse outro menino, essa, essa, essa vizinha que mora aqui, pe, pegou pra, pra, pra curar o imbigo, falou que, que assim que eu cheguei do hospital com o menino, ela falou que ela é que ia curar o imbigo do menino. E despois ela, ela num, num quis continuar, ela só mexeu e num, e num continuou não. Num continuou não. [...]Hum, hum... Pra falar a verdade eu mesmo nunca curei imbigo de menino não, sabe? [...] Eu não mexo porque, se dá poblema a gente, a gente não sabe, né? [...] Eles ensinô, porque, eles falou, o que a enfermera falou comigo, que era pra que quase todas as vez que fosse dá o banho nele, tinha que molhá o imbigo pra tirar o gaizim, né? Aí, elas me, me falô que era pra mim fazer isso, mas eu num fiz porque a gente fica com medo de mexer, com medo de mexer e dá poblema. Eu mesmo num mexo não. [...] Tá doido cara! É igual eles fala, quando a pessoa num sabe não é bom nem mexer, eu não mexo, eu não mexo. [...] Só dessa aí, só desse que morreu, que, minha mãe não tava com cabeça muito ruim, boa, né? E aí, ela pegou e falou que num ia curar o imbigo do menino. E aí, essa vizinha nossa, vem e falou que queria curar o imbigo do menino. [...]Eu mesmo, tem hora, que eu to até boba com o que aconteceu aqui com aquele menino. Eu mesmo, tem hora que eu não gosto, sabe? Igual ela ... O poblema, o poblema é que eu num, tem hora que eu fico até pensando como, como que foi acontecer aquilo.

E.3 Nós é que cuidô. Colocô arruda e um outro negócio no... Eu esqueci o quê que é. E depois que caiu colocô, colocô foi é pena de galinha. Mas só que foi só essa aí, porque a outra num chegô a caí o imbigo em casa. Só que num teve perigo não. Foi pena de galinha, rapidinho fechô. E é só. Foi as enfermeira lá no, lá no hospital é orientou lá.[...] Pra eu passá álcool absoluto no umbigo dela. Falô tudo lá, direito lá. Só que chegô cá tava tudo arrumado já e aí. E a muié acustumada de tratá, de cuidá de umbigo desse jeito. Ela então cuidô. Ela cuidô do umbigo da neném foi com arruda.

E.4 Foi cuidado com álcool absoluto, né! Que é o costume que a gente usa, né! Lá orientaram. A gente sai de lá, né e já sai orientado pelas enfermeira, né! A minha mãe só dava o banho, né! Mas arrumá o imbiguinho eu é que arrumava. Num uso mais nada, só álcool absoluto mesmo.

E.5 Quem cuidô do umbigo foi a mesma mulhé que cortô desses daí. Nós põe aqui é caroço de andú e raspinha de chifre. Todo mundo aqui põe é isso. Esse aqui sarô de repente com raspa de chifre. 


\begin{tabular}{|c|c|}
\hline Idéia central & Expressões-chave \\
\hline $\begin{array}{l}\text { Eu passava os remédios que me deram no hospital. Eu } \\
\text { não passava nada daqui. }\end{array}$ & $\begin{array}{l}\text { E.6 Eu já passava lá os remédio. Aqui eu num passava } \\
\text { nada, era os remédios de lá que eles passô. Só mesmo } \\
\text { da menina. Do mesmo jeito que dos outro. Elas num } \\
\text { falô nada não. }\end{array}$ \\
\hline $\begin{array}{l}\text { Usei álcool. Não usei outro material. Apenas queimava } \\
\text { com álcool. }\end{array}$ & $\begin{array}{l}\text { E.7 Fala no usá, no modo de usá? Não, afinal é, nóis só } \\
\text { usava mesmo é o álcool. Outros material num usei. Em } \\
\text { nenhum deles. Quando dava o banhzinho neles eu vinha } \\
\text { e queimava com o álcool em cima. Até caí, mas eu } \\
\text { continuava passando aquilo lá. Punha um tiquinho na } \\
\text { água, dava o banho assim... E só, mais nada. É, todos } \\
\text { foi curado normalmente. Nunca... Foi os outro, ele } \\
\text { também. De lá pra cá, todos. Eu curava só com álcool. } \\
\text { Eu num usava outro material. Mertolato eu num mexia. }\end{array}$ \\
\hline $\begin{array}{l}\text { A minha mãe usava azeite doce. Às vezes eu passava } \\
\text { azeite de mamona, porque é a mesma coisa que azeite } \\
\text { doce. }\end{array}$ & $\begin{array}{l}\text { E.8 Naquele tempo ela usava é azeite doce. Passava é } \\
\text { azeite doce. Usava azeite doce nesse tempo, né? Inté o } \\
\text { umbigo caí. Essa que morreu aqui passava é azeite, é } \\
\text { azeite doce. Eu tava passando é azeite de mamona. E } \\
\text { depois... Porque azeite de mamona, mamoninha é a } \\
\text { mesma coisa que azeite doce. }\end{array}$ \\
\hline $\begin{array}{l}\text { Antes, eles colocavam esses remédios da roça. Acho } \\
\text { que era rapé e outras coisas. Quem cuidava era minha } \\
\text { vizinha, e ela passava azeite e rapé. }\end{array}$ & $\begin{array}{l}\text { E.9 Uai, lá na roça antes eles colocava era esses } \\
\text { remédio assim da roça, que eles colocava, né? Eles } \\
\text { curava, eu acho era com rapé, outras coisa. Eu num } \\
\text { senti nada não, que ele sentiu não. Que todos curou lá } \\
\text { foi com isso, né? Eu passava aqueles remédio que eles } \\
\text { me ensinava a passá. Que a mulhé me ensinava pra eu } \\
\text { passá, mas cuidava pra mim uma vizinha minha. Era } \\
\text { azeite assim. Esses remédio da roça, né? Que eles } \\
\text { passava. E o rapé, né? [...] Eles num ensinô a cuidá do } \\
\text { umbigo não. }\end{array}$ \\
\hline $\begin{array}{l}\text { Foi minha mãe que cortou o umbigo com a tesoura e } \\
\text { passava azeite fininho. Lá eles não explicaram, mas os } \\
\text { médicos proibiram e não deixavam colocar nada no } \\
\text { umbigo. }\end{array}$ & $\begin{array}{l}\text { E.10 Foi minha mãe que cortô o imbigo. Ela cortô o } \\
\text { imbigo e passava uma, um azeitinho que tira fininho e } \\
\text { passava. É isso que passava. Acho que é com a tesoura. } \\
\text { Cortou o imbigo com a tesoura. Eles não explicô, não. } \\
\text { Que hoje em dia é... Eu esqueci o nome do negócio que } \\
\text { eles coloca, né?[...]. Os médico agora deu pra proibi e } \\
\text { num deixa colocá nada agora não. A minha irmã não } \\
\text { colocô nada não. }\end{array}$ \\
\hline $\begin{array}{l}\text { Eu colocava as coisas que a parteira recomendou. } \\
\text { Colocava azeite para não secar. }\end{array}$ & $\begin{array}{l}\text { E.11 Uê, eu colocava as coisa que ela, que a parteira } \\
\text { falô que, que podia colocá eu punha. Azeite. Pra num } \\
\text { deixá, pra num secá. Era só isso. Aí o umbigo dele num } \\
\text { secô. Ficô diluí assim e soltá. Aí, eu num pus nada mais. } \\
\text { Num tinha como pô. }\end{array}$ \\
\hline $\begin{array}{l}\text { A parteira passava álcool e azeite, que nós fazíamos na } \\
\text { roça. Do que morreu, o pai cuidou com azeite. }\end{array}$ & $\begin{array}{l}\text { E.12 A parteira passava um álcool. É, passava álcool } \\
\text { no umbigo dele. Passava azeitô que nós fazia na roça, } \\
\text { né? É só o que nós passava no umbigo deles, até o } \\
\text { umbiguinho caí. Do que morreu, foi o pai mesmo. Foi o } \\
\text { pai dele que cuidô. Passou azeitô. }\end{array}$ \\
\hline
\end{tabular}




\begin{tabular}{|c|c|}
\hline Idéia central & Expressões-chave \\
\hline $\begin{array}{l}\text { As parteiras cortavam com a tesoura e passavam azeite } \\
\text { no umbigo. Eu não mexia com o umbigo e também } \\
\text { não acompanhava. }\end{array}$ & $\begin{array}{l}\text { E.13 Tem um azeite que eles pronta pra gente passá no } \\
\text { umbigo do menino. As parteiras mesmo que faz isso. Só } \\
\text { o azeite só. Cortava com a tesoura. Com a tesoura é que } \\
\text { corta (risos) Num sei não. Eu não via esse negócio. } \\
\text { Mas, eu acho que eles passa algum negócio. Limpa. O } \\
\text { umbigo dele caiu com até com quatro dias. Num era eu } \\
\text { também que mexia com o umbigo não. [...] E a } \\
\text { enfermeira fazia as coisas. [...] Ela falô comigo, disse } \\
\text { que no menino, pra gente, que num pôde tratá o imbigo } \\
\text { de menino com azeite. Tem que passá outra coisa no } \\
\text { imbigo de menino. [...] Mas ela me deu de outro menino } \\
\text { quando eu fui ganhar o menino na cidade. Daquele ela } \\
\text { não deu. Deu pra usá noutro menino }\end{array}$ \\
\hline $\begin{array}{l}\text { Foi minha mãe que me orientou e também cuidou } \\
\text { deles. Naquele tempo era com azeite. Quando não caía } \\
\text { o umbigo, eles colocavam um pozinho de casca de } \\
\text { goiaba. }\end{array}$ & $\begin{array}{l}\text { E.14 Recebi quando eu tava dentro da casa da minha } \\
\text { mãe, né? E aí era eu e mais ela. Me orientou direitinho, } \\
\text { né? Como cuidar. A bem dizer foi ela quase que cuidou } \\
\text { deles, dos mais velho, que mora com ela. Ela falava } \\
\text { assim comigo.... como era pra fazer, como dar banho. } \\
\text { Ela é que dava banho, trocava os menino, ajeitava o } \\
\text { umbigo, tudo. Naquele tempo era com azeite (risos), } \\
\text { com azeite. Quando o menino num caia o umbigo, eles } \\
\text { colocava um pozinho de casca de goiaba. [...] Agora } \\
\text { desse menino meu que morreu, eu ganhei ele lá assim } \\
\text { de noite, de madrugada. Não deu pra podê coisá nada, } \\
\text { né? Ai a muié pegou a tesoura lá na minha sogra e } \\
\text { cortou o umbigo lá. Eu não sei como tava essa tesoura e } \\
\text { nada. }\end{array}$ \\
\hline $\begin{array}{l}\text { Meu filho foi curado com azeite. Lá no hospital não } \\
\text { deram nenhuma orientação. }\end{array}$ & $\begin{array}{l}\text { E.15 [...] Lá, as vezes chega lá. A gente ganha de } \\
\text { manhã. Quando é no outro dia de manhã, a gente já tem } \\
\text { alta. Aí, só entra na sala mesmo só pra dá banho na } \\
\text { criança. Trocô a criança, entregô nóis e saiu. Só isto. } \\
\text { Num deram orientação. Sobre vacina também não. Os } \\
\text { outro? Um foi curado com, foi curado com azeito, com } \\
\text { azeito. E foi nesse dia, momento que aconteceu isto que } \\
\text { o médico de lá, né? Começou a me falar essas coisas e } \\
\text { eu já coloquei aquilo na cabeça. Um foi curado com } \\
\text { azeito. }\end{array}$ \\
\hline $\begin{array}{l}\text { Cuidei com álcool absoluto. Do jeito que os médicos } \\
\text { me orientaram. Dizem que não se pode mais curar o } \\
\text { umbigo como antigamente, com azeite, porque senão } \\
\text { dá tétano. }\end{array}$ & $\begin{array}{l}\text { E.16 Ah, eu cuidei direitinho, do jeito que os médicos } \\
\text { me orientou, eu cuidei.Foi álcool absoluto, aquele } \\
\text { álcool que a gente compra. Diz que não pode curá o } \\
\text { umbigo igual os antigo com azeite, né? Que pode } \\
\text { prejudicar o tétano. }\end{array}$ \\
\hline $\begin{array}{l}\text { Eu usei mercúrio, e o umbigo dele curou logo. Não } \\
\text { usei óleo de mamona. }\end{array}$ & $\begin{array}{l}\text { E.17 [...] No que morreu o modo de observar o imbigo } \\
\text { dele foi lá no hospital, em Brasilia, internado lá. Em } \\
\text { casa tava usando nele era, era mercúrio e aí depois que } \\
\text { assim antes de com } 6 \text { dias o imbigo dele curou logo, e } \\
\text { passou assim } 7 \text { dias certinho eu levei pro hospital, e aí } \\
\text { já não tava mamando né? Num tava usando óleo de } \\
\text { mamona não. }\end{array}$ \\
\hline
\end{tabular}




\begin{tabular}{|c|c|}
\hline Idéia central & Expressões-chave \\
\hline $\begin{array}{l}\text { Colocaram pó e azeite. Eu não posso falar mentira. Eu } \\
\text { não sei o que aconteceu, porque elas cuidam } \\
\text { direitinho. Acho que não tive sorte. Mas acho que não } \\
\text { era tétano, porque foi depois de sete dias. }\end{array}$ & $\begin{array}{l}\text { E.18 Pó e azeite. Colocaram foi isso. Eu não posso falar } \\
\text { mentira, né? Que hoje não usa isso mais. Agora eu não } \\
\text { sei o que deu. Se nesse dia distraiu, né? Com alguma } \\
\text { coisa. Porque elas é que cuidam. Tem uma dona aqui de } \\
\text { cima, tá até pra ganhá neném, que, que olha direitinho, } \\
\text { que cuidou da menina da cunhada minha. Cuida } \\
\text { direitinho. Eu não sei o quê que deu. Eu acho que não } \\
\text { tive sorte, entendeu? Aconteceu que deu isso aí. Eu } \\
\text { acho que não tinha teto não? Depois de } 7 \text { dias, né? }\end{array}$ \\
\hline $\begin{array}{l}\text { Coloquei azeite, mas os médicos de Araxá teimaram } \\
\text { que eu tinha colocado pó de fumo no umbigo do } \\
\text { menino. Eu só dava banho depois que o umbigo caía, } \\
\text { porque ficava com medo de machucar a criança. }\end{array}$ & $\begin{array}{l}\text { E.19 [...] Uai, eu sempre coloquei é azeite. Inclusive o } \\
\text { primeiro eu curei com azeite. Esse outro também eu } \\
\text { tava curando é com azeite. Agora eles lá no Araxá tava } \\
\text { temando que eu tinha colocado era pó de fumo no } \\
\text { umbigo do menino. Eu disse assim: ocês tá é doido! Eu } \\
\text { num pus isso não. Ai, a muié falô assim: É você que } \\
\text { tava cuidando é que sabe. [...] Do azeite foi meu pai que } \\
\text { trouxe e deixô lá pra mim. Eu num sei quem que fez. } \\
\text { [...]. Num era eu que dava banho neles não.[...]. E eu } \\
\text { nunca dei banho neles assim, só quando caía o umbigo, } \\
\text { sabe? Enquanto tava com umbigo eu num dava nâ, } \\
\text { porque eu ficava com medo de machucá, porque a gente } \\
\text { num tem muita experiência, né! Aí, era sempre as } \\
\text { minhas tia que dava. [...] a médica e a menina que } \\
\text { ficava lá no berçário falô que tinha que colocá é } \\
\text { mertiolate. Eu num sei se era mertiolate ou se era } \\
\text { mercúrio. }\end{array}$ \\
\hline
\end{tabular}

Neste tópico, a partir das idéias centrais agrupadas em relação aos cuidados com o coto umbilical, resultantes das falas muito heterogêneas das mulheres que compõem o grupo, obtivemos os seguintes "discursos dos sujeitos coletivos":

1. Aqui na roça a minha mãe cortava com uma tesourinha e amarrava. Depois colocava rapé feito com fumo picado e batido. Notei apenas que ele estava chorando muito, por isso eu o levei para o hospital.

2. O problema surgiu porque a menina que começou a cuidar do umbigo não voltou para continuar. Eu não cuido porque tenho medo de dar problema. Quando a pessoa não sabe cuidar, é bom nem mexer. Lá no hospital, não deram nenhuma orientação. Há momentos em que fico até pensando como isso foi acontecer. 
3. Foi cuidado com arruda e pena de galinha. As enfermeiras do hospital orientaram direitinho, mas, quando chegamos em casa, uma mulher acostumada a cuidar de outro modo já havia preparado tudo. Foi cuidado com arruda e pena de galinha.

4. As enfermeiras me orientaram, e eu é que cuidava do umbigo. Foi cuidado com álcool absoluto. Foi queimado com álcool. Eu não uso mais nada, somente o álcool absoluto. A minha mãe só dava o banho.

5. Todos aqui usam é caroço de andu e raspa de chifre. A mesma mulher que cortou o umbigo também cuidou dele.

6. A minha mãe usava azeite doce. Às vezes eu passava azeite de mamona, porque é a mesma coisa que azeite doce. Quando não caía o umbigo, eles colocavam um pozinho de casca de goiaba. Os médicos, porém, proibiram passar essas coisas.

7. Antes eles colocavam esses remédios da roça. Acho que era rapé e outras coisas. Quem cuidava era minha vizinha, e ela passava azeite e rapé. Eu não percebi nada, pois todos foram curados dessa maneira.

8. Eu não posso falar mentira, foi pó e azeite que colocaram. Eu não sei o que aconteceu, porque elas cuidam direitinho. Eu acho que não tive sorte. Mas eu acho também que não era tétano, porque foi depois de sete dias.

A família influi na adoção de hábitos, estilos e condutas relevantes no processo de saúde e de doença. Seja indicado por parteiras ou mesmo por integrantes do grupo familiar ou social, é muito freqüente a utilização de substâncias diferentes do álcool absoluto, associadas ou não, para os cuidados do coto umbilical.

As entrevistadas relataram que utilizam azeite, arruda, casca de goiaba, feijão andu, mercúrio, pena de galinha, rapé e raspa de chifre no tratamento do coto umbilical, prática considerada comum no meio social em que vivem. Tratando-se de mulheres 
multíparas, como não houve problema com a adoção dessas práticas para cuidar do coto umbilical de outros filhos, elas não associam a doença ao uso dessas substâncias, mas à falta de sorte ou mesmo a crenças associadas ao mal-de-sete-dias, como veremos mais adiante.

Mesmo que a mulher tenha sido orientada sobre a forma correta de prestar esse cuidado, a influência do grupo social a que pertence é tão forte que paira a dúvida entre as novas orientações e as antigas. Do outro lado, algumas mães têm receio de machucar a criança e delegam essa tarefa a outra pessoa, que nem sempre está preparada. O medo é uma característica do ser humano, um comportamento de conservação.

Nenhuma das mulheres fez menção à visita do agente comunitário de saúde ou a outro profissional de saúde durante a gravidez ou o período neonatal, para prestar orientações sobre amamentação, cuidados com o recém-nascido ou esclarecer dúvidas. É imprescindível o acompanhamento das puérperas mediante visita domiciliar, reforçando as orientações recebidas durante o pré-natal quanto aos cuidados com o coto umbilical.

A expressão "mal-de-sete-dias" ainda esteve presente nas falas de algumas mães que relacionaram o mal ao tétano, entretanto, quando a criança adoece depois dos sete dias, elas colocam em dúvida a declaração da doença responsável pelo óbito da criança, associando-a a outros fatos.

O cuidado correto com o coto umbilical, por si só, não isenta a possibilidade da doença se a mulher não for devidamente imunizada, pois muitas vezes a prática de corte do cordão umbilical pode ser o meio de entrada para a infecção, sobretudo quando não foi feita de forma asséptica.

Além de reforçar os trabalhos já realizados de incentivo à inserção ao pré-natal e da vacinação antitetânica para gestantes e mulheres em idade fértil, é necessário o incremento de trabalhos educativos apoiados pela divulgação da mídia, reforçando a importância do prénatal e os cuidados corretos antes, durante e depois do parto. 
A comunicação consiste num processo educativo indispensável para a assistência à saúde, além de constituir um recurso para estabelecer a vinculação do usuário ao profissional e ao serviço de saúde.

\section{Desenvolvimento do Instrumento de Análise de Discurso - 2 (IAD-2)}

\section{A senhora sabe o que é "mal-de-sete-dias "?}

\begin{tabular}{|l|}
\hline \multicolumn{1}{|c|}{ Idéia central } \\
\hline Eu já ouvi falar de mal-de-sete-dias. O povo diz que \\
quando ocorre o mal-de-sete-dias as crianças morrem. Eu \\
não fiquei sabendo se meu filho morreu foi de mal-de- \\
sete-dias.
\end{tabular}

Eu não sei o que é mal-de-sete-dias. Eles dizem que é tétano que deu no umbigo do menino.

é

Eu já ouvi falar de mal-de-sete-dias. Minha mãe falava que menino morria com sete dias, com mal-de-sete-dias. Ela disse que morre com esse mal assim que faz sete dias. Eu não acredito que minha filha tenha morrido com mal-de-sete-dias.

E.1 Não. É, eu já vi falar. Eu sei assim, que o povo fala que quando dá o mal-de-sete-dia que eles morre, né? Eles vão chorando, chorando, até que morre, com o mal-de-sete-dia. [...] Eu não fiquei sabendo se foi o mal-de-sete-dia, pois ele morreu e eu vim embora. Eu não fiquei sabendo. Ele foi sepultado no Planalto aqui. Foi a primeira vez que morre uma criança aqui. Depois dele eu ainda não quis ter mais filho não. Antes dele foi seis filhos, com ele sete.

E.2 Num sei não. Eles fala que é teto que deu no imbigo do menino, né?

E.3 Minha mãe só, sempre falava comigo desse negócio de... Que menino morria com sete dia, com mal-de-sete-dia. Só que diz que morre com mal é assim que faz sete dia. Só que ela morreu tava com dois mês. Oh, diz a minha mãe que era uma irmã dela é que teve. [...] Só que eu mesmo num sei direito não. Eu já ouvi falá disso. Só que eu num tenho conhecimento disso não. Eu só vi falá pra lá só, mas eu nunca prestei atenção direito não. Agora que ouvi falá nas coisa de doença assim, eu presto mais atenção poquê a gente que tem menino... Eu presto mais atenção mais nas coisas pra sabê de reação de menino, pra sabê do jeito que é pra gente sabê cuidá.

Eu já ouvi falar de tétano. Eles disseram que é muito perigoso e que a gente tem de usar álcool absoluto no umbigo para não dar essa doença.

E.4 Num sei. Této também num sei. Já ouvi falá. Eles falaram que a gente tem que usá álcool absoluto poquê senão vai této no imbigo. E é muito perigoso. Foi isso que falaram comigo.

Eu não sei muito bem, mas o mal-de-sete-dias faz com que a cabeça deles seja rachada. Então, eles não raciocinam nada.

E.5 Eu num sei não. É mal-de-sete-dia por isso... Poquê quando eles nasce num raciocina nada. A cabeça deles é rachada aqui assim, aqui assim. Esse aqui também tem.

Eles falaram que ela morreu foi de mal. Eles só E.6 Se eu sei? (silêncio). Eles falô que ela morreu foi escreveram que foi com mal. de mal. Eles só colocava lá que foi de mal.

Eu ouvi falar de mal-de-sete-dias e de tétano, mas não sei o que significa.
E.7 Já ouvi falá. Eles fala mal-de-sete-dias, né? Eu num sei não. Tétalo também não. Eu vejo falá, mas num sei o que significa. Eu só vi o médico falá, né? 


\begin{tabular}{|l|}
\hline \multicolumn{1}{|c|}{ Idéia central } \\
\hline Eu ouvi falar de mal-de-sete-dias e de tétano, mas não \\
entendo. Alguém mais velho me disse que antigamente \\
se morria de mal-de-sete-dias.
\end{tabular}

\section{Expressões-chave}

E.8 ] Eu num gravei na cabeça não. Sei não. É poquê tem tempo isso, né? Tá com quatro anos, cinco anos, talvez se fosse mais de novo eu inté lembrasse. Eu não sei não. Eu já esqueci. Eu não. Num intendo. Num sei o quê que é isso não. Nem isso. Num sei também não. Essa coisa, esse aí. Ah, esse ai eu acho que... Alguma pessoa falô pra mim. Essas pessoa de mais idade, né? Falô comigo. Antigamente morria de mal-de-sete-dia. Agora eu num sei de que é isso. Se é mal-de-sete-dia, num sei o que quê é? Se é teto, num sei o que quêé? É só mais essas pessoa sabida que tira do, as vezes acha assim na medicina, né? É que sabe.

Eu acho que o médico falou que ele morreu foi de mal de umbigo. Eu não sei e não ouvi falar de tétano.

Eu já ouvi falar de mal-de-sete-dias. Muitas pessoas disseram que não adiantava levar meu filho para o hospital. Mas eu levei para ver se ele melhorava.
E.9 Eu num sei não. Ele faleceu foi no hospital. O médico, eu acho que falô que ele deu foi o mal de umbigo. Mal de umbigo que deu nele. Eu num sei não. Eu num ouvi falá de tétano não.

E.10 Já. Mal-de-sete-dias já vi. Que muitas disse que quando tem mal, que num tinha que levá. Poquê que era o mal-de-sete-dias, né? De lá pra cá, disse que muitas crianças morria assim, né? De mal-de-setedias. Ai eles disse que eu num tinha que levá, mas eu levei pra ver se ele sarava. Pra Deus dá ele saúde. Eu levei, né? Que ia levá pra ver se ele melhorava. Mas muita pessoa falava que eu num tinha que levá não, poquê era essa doença mal-de-sete-dias.

Eu não conheço direito, mas o povo diz que, quando dá o mal-de-sete-dias, as crianças morrem com os ossinhos da cabeça quebrados. Mas o médico falou que foi por falta de cuidado com o umbigo dele. Eu já ouvi falar de tétano, mas também não conheço direito.

E.11 Ah, o povo me conta, né? Eu num conheço direito não. Mas, o povo me fala que o mal-de-setedias é assim quando eles morre que quebra o ossinho da cabeça toda. Que estoura os ossinho toda assim e rouxeia as unhas, a boca. Foi isso que eles me falo, que é o mal-de-sete-dias é assim. Eu num sei, que um cado do povo da família dele falo que era o mal-desete-dias, né? Mas o médico falô que foi falta de cuidado com o umbigo dele. Eu num sei. Tétano eu num conheço direito essa doença não. Eu já ouvi falá. Tétano. Eu num sei que doença é não.

Sobre mal-de-sete-dias eu sei pouco. Lá em Teófilo Otôni eles disseram que ele teve foi mal de umbigo. Eu acho que mal de umbigo é a mesma coisa que tétano.

Eles falam que o menino adoece. É um mal que dá, chamado mal-de-sete-dias.

Eu esqueci o que é mal-de-sete-dias. As vacinas são para evitar o mal-de-sete-dias na criança.
E.12 Se eu sei? Mal-de-sete-dias eu não sei muito não. Ele sentiu foi mal, né? Foi uma cólica brava. Que num teve jeito não, né? Lá em Teófilo Otôni eles diz que é mal de umbigo. Essa doença aí eu num sei como é que ela chama não. Essa doença é mesmo que mal de umbigo mesmo, né? Tetro é mal de umbigo mesmo.

E.13 Eles fala assim, que o menino doece. Que é um mal que dá. O mal-de-sete-dias.

E.14 Eu não, eu esqueci. O menino de meu cunhado aqui, esse que caminha patinando. Foi mal-de-setedias. As vacinas é pra isso aí, né? Pra não dá o mal no menino, né? Na criança. [...] O doutor Joaquim mesmo, aí, no hospital em Maxacalis, falou pra mim que podia trazê o menino pra casa poquê o menino num tinha jeito mais, né? Porque era mal-de-setedias que era. 


\begin{tabular}{|c|c|}
\hline Idéia central & Expressões-chave \\
\hline $\begin{array}{l}\text { Já ouvi falar de mal-de-sete-dias. Acho que tétano é uma } \\
\text { coisa e mal-de-sete-dias é outra coisa. Eu fui saber o que } \\
\text { é tétano depois que minha filha tinha falecido. }\end{array}$ & $\begin{array}{l}\text { E.15 Eu já ouvi falá de tétro. Foi depois do que } \\
\text { aconteceu com a minha menina. Depois disso aí é que } \\
\text { foi que eu fui sabe, aliás, depois disso aí a menina } \\
\text { tinha, tinha falecido, com } 10 \text { dias, com } 10 \text { dias, com } \\
14 \text { dias eu operei. Eu tava de resguardo, fraca, } \\
\text { sentida, depois eu operei. Operei em Divisópolis, não } \\
\text { operei em Conquista. Apesar de que, depois dessa } \\
\text { operação eu fiquei com muitos, com muitos problema, } \\
\text { sabe? Com muitos problema. Já ouvi falá de mal-de- } \\
\text { sete-dias. Eu não sei. Eu acho que tetro é uma coisa e } \\
\text { mal-de-sete-dias é outro. }\end{array}$ \\
\hline $\begin{array}{l}\text { O que eu sei do mal-de-sete-dias é que a criança não } \\
\text { pode tomar vento e nem resfriado. Ela não pode ter tido o } \\
\text { mal-de-sete-dias porque não pegou vento nem resfriado. } \\
\text { Eu acho que o mal dela foi porque nasceu fraca. }\end{array}$ & $\begin{array}{l}\text { E.16 Mal-de-sete-dias que não pode tomá vento, né? } \\
\text { Não pode tomá resfriado, né? O que eu sei é isso. } \\
\text { Não deixa tomá, né? Principalmente o vento frio, né? } \\
\text { É isso que nóis faz aqui na roça. Minha filha não } \\
\text { pode ter pegado o mal-de-sete-dias porque não } \\
\text { panhou vento nenhum, né? Não teve resfriado } \\
\text { nenhum, né? Eu acho que o mal que chegou ao } \\
\text { conhecimento dela, porque eu acho que ela nasceu } \\
\text { fraca, o líquido dela, né? Eu tava perdendo líquido, } \\
\text { ela nasceu uma menina muito fraca e não suportou, } \\
\text { né? }\end{array}$ \\
\hline $\begin{array}{l}\text { Eu já ouvi falar de mal-de-sete-dias, mas não sei o que é. } \\
\text { Eu não sei o que é tétano também. O meu filho adoeceu, } \\
\text { travou o queixinho, não conseguia chorar e não mamava. } \\
\text { É só isso que eu sei explicar sobre tétano. }\end{array}$ & $\begin{array}{l}\text { E.17 Já ouvi falar de mal-de-sete-dias, mas eu não sei } \\
\text { não (risos), o que é não e nun ... nunca vi não. Eu não } \\
\text { sei o que é tétano também não. Eu sei que o meu } \\
\text { assim adoeceu, serrou o queixinho, não conseguiu } \\
\text { chorar, não mamava. Eu sei explicá do tétano é só até } \\
\text { aí. }\end{array}$ \\
\hline $\begin{array}{l}\text { O que eu sei do mal-de-sete-dias é que a criança não } \\
\text { pode sair de casa. Deve ficar fechada no quarto e com a } \\
\text { tesoura aberta na parede. Mas eu acho que tem um monte } \\
\text { de bobagem. Minha filha teve foi tétano. }\end{array}$ & $\begin{array}{l}\text { E.18 Sei. O mal-de-sete-dias é que o menino não pode } \\
\text { sair pra fora, né? Fechado num quarto, tesoura } \\
\text { aberta na parede. Não deixá toma ar, né? Pra bem } \\
\text { dizer, eu acho que tem um monte de bobagem. [...] } \\
\text { Ela caiu o imbigo com } 8 \text { dias ... com } 8 \text { dias deu } \\
\text { poblema do tetro. }\end{array}$ \\
\hline $\begin{array}{l}\text { Eu já ouvi falar de mal-de-sete-dias. Eles dizem que não } \\
\text { se pode sair de casa com a criança nem dar banho nela } \\
\text { até completar os sete dias. Na minha filha banho eu dei, } \\
\text { só não saí com ela de casa. Eu não sabia de tétano. Eu } \\
\text { acho que mal-de-sete-dias é uma coisa e tétano é outra. }\end{array}$ & $\begin{array}{l}\text { E.19 Eu já vi fala. Uai eles fala que num pode saí } \\
\text { com a criança inté os sete dia. Num pode saí com a } \\
\text { criança pra fora. Eles fala que num pode dá banho. } \\
\text { Isso é o que eu intendo. [...] Nas minha eu dei, o } \\
\text { banho eu dei. Eu só num saí com elas porquê eles fala } \\
\text { que num pode vê a claridade do dia. Vê a claridade } \\
\text { do dia eu num deixava eles vê mesmo não. Inclusive, } \\
\text { de saí com a criança pra fora. Bem eu num lembro de } \\
\text { tetro não. Somente eu num sabia. Chegô lá no Araxá } \\
\text { eles colocô no papel. Uai, diz eles que somente se ficá } \\
\text { sem tomá a vacina. Tomá a vacina, eu tomei. Mal-de- } \\
\text { sete-dias e tetro ? Eu acho que uma coisa é outra, } \\
\text { uma é outra. }\end{array}$ \\
\hline
\end{tabular}


Das idéias centrais agrupadas, em relação a conhecer o mal-de-sete-dias, resultantes das falas muito heterogêneas das mulheres que compõem o grupo, obtivemos os seguintes "discursos dos sujeitos coletivos":

1. Eu já ouvi falar de mal-de-sete-dias, mas não tenho muito conhecimento. Só sei que dizem que morre com esse mal assim que faz sete dias. Eles vão chorando, chorando até morrer com o mal-de-sete-dias. Eu não fiquei sabendo se meu filho morreu com mal-de-setedias.

2. Eu já ouvi falar de mal-de-sete-dias. Minha mãe falava que menino morria com sete dias, com mal-de-sete-dias. Eu não acredito que minha filha morreu com mal-de-setedias, pois ela morreu com mais de sete dias.

3. O que eu sei do mal-de-sete-dias é que o neném não pode tomar vento e nem resfriado. Minha filha não pode ter tido o mal-de-sete-dias porque não pegou vento nem resfriado. Eu acho que o mal dela é ter nascido fraca.

4. Eu não sei o que é mal-de-sete-dias. Eles falam que é tétano que deu no umbigo do meu filho. Eles falaram que é muito perigoso e que a gente tem de usar álcool absoluto para não dar tétano no umbigo. Acho que mal de umbigo é a mesma coisa que tétano, mas acho que tétano não é a mesma coisa que mal-de-sete-dias.

5. O que eu sei do mal-de-sete-dias é que o neném não pode sair de casa nem tomar banho até completar os sete dias. Deve ficar fechado no quarto, não pode ver a claridade e com a tesoura aberta na parede. Mas eu acho que tem um monte de bobagem. Eles colocaram no papel que minha filha teve foi tétano e disseram que isso ocorre se a mãe ficar sem tomar a vacina. Eu acho que mal-de-sete-dias é uma coisa e tétano é outra.

6. Eu já ouvi falar de mal-de-sete-dias. Eles falam que não pode sair de casa nem dar banho no neném até completar os sete dias. Na minha filha eu dei banho, só não saí com ela de casa. Eu não sabia de tétano. Só soube quando minha filha morreu. 
7. Eu não sei muito bem, mas o mal-de-sete-dias faz com que a cabeça deles seja rachada, de modo que eles não raciocinam nada. Quando morrem, estão com os ossinhos da cabeça quebrados.

8. Eu esqueci o que é mal-de-sete-dias, mas o médico me disse que meu filho teve essa doença e que não sobreviveria. As vacinas são para evitar o mal-de-sete-dias na criança.

9. Eu já ouvi falar de mal-de-sete-dias, mas não sei o que é. Eu não sei o que é tétano também. Meu filho adoeceu, travou o queixinho, não conseguia chorar e não mamava. É só isso que eu sei explicar sobre tétano.

As representações contidas nos depoimentos das mães não refletem só elementos de "senso comum", elas também se constroem sobre a base dos seus aprendizados e de suas próprias reflexões, em torno do conhecimento científico. As mães vão mudando suas interpretações como conseqüência da transição de saberes que, segundo o pensamento gramsciano, devem acontecer como resultado do processo educativo. Referimo-nos aqui ao saber do "bom senso", ou seja, a obtenção de conhecimentos mais concretos, complexos, que permitem às mães fazer uma reflexão interna e reconstruir as suas antigas concepções.

O mal-de-sete-dias ainda se faz presente no imaginário e nas condutas de saúde de muitas mulheres quando lidam com o recém-nascido. Há momentos em que a mãe correlaciona o mal-de-sete-dias ao tétano neonatal e noutros essa correlação está ausente.

Em decorrência da expectativa das crendices que envolvem o mal-de-sete-dias, já mencionadas anteriormente, muitas mães aguardam passar esse período crítico para escolher o nome da criança. Nas comunidades rurais, procura-se cumprir uma série de condutas em relação ao recém-nascido para evitar o "mal-de-sete-dias", protegendo-o da claridade e da ventania. A puérpera, durante o resguardo, procura evitar o contato permanente com a criança até completar os primeiros sete dias, restringindo-se à amamentação. $\mathrm{O}$ banho e os cuidados 
com o coto umbilical são delegados a terceiros. Durante os primeiros sete dias, a parteira costuma assumir os cuidados da criança e algumas tarefas da casa, incluindo a preparação de sopas e caldos para a puérpera.

Rocha (1985) considera que o resguardo deve ter sido concebido a partir da observação da natureza pelo homem, ao verificar comportamento dos animais que, ao se encontrarem debilitados ou doentes, recolhem-se para o repouso e passam, inclusive, a jejuar até se recuperar. Portanto, o saber popular em saúde parte de certos referenciais vinculados a uma tradição oral transmitida ao longo do tempo, com a incorporação de experiências da vivência cotidiana.

Por intermédio das entrevistas, há indícios de que o uso das expressões "tétano umbilical", "mal do umbigo" e até "mal-de-sete-dias", sendo as duas últimas de uso popular, poderiam auxiliar na veiculação das medidas preventivas do tétano neonatal para que a população tivesse melhor clareza a que doença se refere. 


\section{CONSIDERAÇÕES FINAIS}

No início desta pesquisa, perguntava-me sobre as possíveis medidas de proteção que as mães utilizam na prevenção do tétano neonatal. Queria, portanto, refletir sobre as representações em torno da doença e dos limites de risco que levam ou não as mulheres a buscar proteção.

Ao analisar seus relatos, enfocando a trajetória relativa ao acontecimento "tétano neonatal" na vida de seus filhos, verifiquei que as mães não escolhem o risco deliberadamente, mas são envolvidas por ele nas circunstâncias do cotidiano da vida.

Já que tiveram experiências anteriores com filhos que não tiveram a doença, as falas apontam para um imaginário sociocultural que mantém a idéia de que nunca pensam que o filho possa ser acometido de tal doença, portanto não se observou um comportamento ativo das mães para buscar a prevenção pela vacina, mesmo que informadas a respeito.

De modo geral, nas entrevistadas falou-se a respeito de práticas populares sedimentadas, relacionadas a cuidados para si e para os recém-nascidos, principalmente durante os primeiros sete dias, período que geralmente coincide com a queda do cordão umbilical, no sentido de evitar que a criança adoeça ou que a mãe possa provocar-lhe algum mal. Nesse sentido, parece haver um risco não calculado permeando tais atitudes: "O risco é inerente à condição do homem [...], a vida cotidiana multiplica as ocasiões de risco por falta de atenção, negligência, desconhecimento de lugar, ou imperícia dos outros” (LE BRETON, 1995, p.7). 
Certas práticas de cuidado com o cordão umbilical estão há tanto tempo sedimentadas que, mesmo ao serem orientadas quanto ao uso apenas do álcool absoluto, não há a garantia de que será utilizado.

As representações sobre o risco para o tétano neonatal encontradas nos relatos das mães inscrevem-se em um contexto ora de conhecimento, ora de desconhecimento dele. Essa racionalidade cognitiva, porém, não é o maior fundamento que diferencia o comportamento para buscar a prevenção da doença.

A percepção do risco, apesar de ser identificada, não aparece no momento de exposição ao agente, e sim no momento do adoecimento, no qual o significado do risco para essas pessoas passa a ser real e vivido. Isso faz com que o desafio se transforme em vigilância e proteção, com a utilização correta da vacina antitetânica. Aqui, vale lembrar que uma coisa é dizer a uma mulher que em tais situações existe o risco do tétano neonatal, e outra é entender como essa mulher se sente ou não em perigo.

Os resultados deste estudo apontam que uma atitude é sempre definida de acordo com a percepção que o sujeito tem do risco, uma vez que este está sempre subjetivamente relacionado aos acontecimentos futuros. Desse modo, as práticas no presente vão depender da capacidade de reconstrução contínua do sujeito nas suas interações com os outros, para definir seus próprios limites e fazer escolhas.

Diferentemente do que ocorre entre outros animais, pelo menos três características tornam a doença infecciosa humana distinta: o doente não apenas sofre dor e limitações funcionais, mas elabora representações da sua experiência que é parte inerente do seu problema. Isso possibilita, mediante mecanismos de comunicação, a troca de conhecimentos, que resulta na atribuição de significado ao evento. Conseqüentemente, as respostas às 
agressões dos microorganismos não serão apenas fisiológicas, mas também comportamentais, dotadas de intencionalidades, mediadas pela cultura do grupo ao qual pertence.

A sistematização da coleta e notificação de eventos vitais e de saúde são ferramentas imprescindíveis para a tomada de decisões em relação à definição de políticas de saúde, na obtenção de recursos públicos para o setor, no monitoramento dos agravos à saúde, na avaliação do impacto das políticas de prevenção e da qualidade dos serviços prestados.

Muitas complicações da gravidez, do parto e do puerpério, assim como doenças do período perinatal, podem ser evitadas se houver uma atenção pré-natal adequada. No entanto, a dificuldade de acesso aos serviços de saúde, principalmente para a população de baixa renda, justamente aquela que por suas condições de vida inadequadas suporta os maiores riscos, favorece a ocorrência de agravos à saúde. Portanto, a falta de acompanhamento no pré-natal como no período neonatal contribuiu para o desenlace fatal dos casos deste estudo.

Há algumas causas de morte relativamente fáceis de ser controladas, mesmo em circunstâncias de baixo nível de desenvolvimento socioeconômico, dependendo muito mais de vontade política, como é o caso das doenças imunopreviníveis, evitáveis pela aplicação de vacinas específicas, sem que haja necessariamente melhoria nas demais condições de vida da população.

A implementação de estratégias, como o Programa de Saúde da Família e o Programa de Agentes Comunitários de Saúde, contribuirá para que a atenção básica de saúde esteja ao alcance das populações carentes, principalmente nas áreas rurais e nas áreas urbanas periféricas, as quais tem dificuldade de acesso aos serviços de saúde, de modo a possibilitar o alcance do ideário de saúde para todos. 
É preciso também que os gestores conheçam a contribuição que as parteiras prestam ao município, atendendo às mulheres que as recorrem. Precisam, mais que isso, reconhecer a importância da parteira e da inclusão do atendimento domiciliar no elenco de suas preocupações de garantia de uma atenção para mãe e recém-nascido de qualidade.

Além de ter proporcionado uma oportunidade de reflexão para mim, enfermeiro e docente da área de saúde pública, esta pesquisa possibilitou também esclarecer dúvidas, permitindo a compreensão das representações que permeiam o imaginário social entre mães que experienciaram o adoecimento de seus filhos por tétano neonatal, apontando uma nova possibilidade de praticar a prevenção dessa doença que considere a visão de mundo que o sujeito tem em relação a esse objeto.

Embora não fizesse parte dos objetivos do trabalho, ao final de cada entrevista procurei esclarecer as dúvidas das mulheres e familiares em relação ao tema em questão, quando foram prestadas informações e orientações sobre o tétano e seus mecanismos de prevenção. O material bibliográfico sobre a doença foi distribuído para ao gestor municipal e às equipes de saúde, incluindo as diretrizes do Plano de Eliminação do Tétano Neonatal. Quando foi possível visitar as unidades de saúde dos municípios, ao observar qualquer irregularidade na Sala de Vacinas, entre elas problemas nas geladeiras ou nas caixas de poliuretano, os fatos foram comunicados imediatamente ao supervisor local e ao supervisor regional para que pudesse ser corrigida.

Esta pesquisa aponta para a possibilidade e a necessidade de realização de outras pesquisas que possam aprofundar sobre o tema, considerando a fala de outros atores sociais envolvidos na prestação da assistência à saúde da mulher e do recém-nascido. 


\section{ANEXOS}

\section{ANEXO 1}

Implantação, número de equipes e cobertura do Programa de Saúde da Família nos municípios onde ocorreram óbitos por tétano neonatal em Minas Gerais, entre 1997 e 2002

\begin{tabular}{|c|c|c|c|c|c|}
\hline CIDADE & $\begin{array}{l}\text { POPULAÇÃO } \\
\text { (HAB.) }\end{array}$ & $\begin{array}{l}\text { DATA DO } \\
\text { ÓBITO }\end{array}$ & $\begin{array}{c}\text { MÊS E ANO DE } \\
\text { IMPLANTAÇÃO } \\
\text { PSF }\end{array}$ & $\begin{array}{c}\text { NÚMERO } \\
\text { DE EQUIPES }\end{array}$ & $\begin{array}{c}\text { COBERTURA } \\
\text { PSF } \\
\%\end{array}$ \\
\hline Água Boa & 18.419 & $11 / 03 / 2002$ & $09 / 2002$ & 04 & 74,0 \\
\hline São João das Missões & 11.341 & $12 / 01 / 2002$ & $12 / 2001$ & 01 & 30,4 \\
\hline Ladainha & 15.595 & $29 / 04 / 2001$ & $08 / 2000$ & 04 & 88,4 \\
\hline Coronel Fabriciano & 100.535 & $17 / 01 / 2000$ & $12 / 1999$ & 03 & 10,3 \\
\hline Carbonita & 9.205 & $31 / 01 / 2000$ & $04 / 1998$ & 03 & 100,0 \\
\hline Umburatiba & 2.850 & $16 / 05 / 2000$ & 04/1998 & 01 & 100,0 \\
\hline Novo Oriente de Minas & 10.321 & $15 / 11 / 1999$ & $11 / 2002$ & 02 & 66,9 \\
\hline Catas Altas da Noruega & 3.260 & $10 / 09 / 1999$ & $08 / 2002$ & 01 & 100,0 \\
\hline São João da Ponte & 25.969 & 02/09/1999 & 04/1998 & 03 & 39,9 \\
\hline Rio Pardo de Minas & 27.674 & $14 / 10 / 1999$ & $04 / 1998$ & 09 & 100,0 \\
\hline Rubelita & 10.258 & 13/06/1999 & $04 / 1998$ & 02 & 67,3 \\
\hline Iapu & 9.634 & 21/06/1999 & $01 / 2002$ & 03 & 100,0 \\
\hline Araguari & 105.267 & $19 / 05 / 1999$ & 08/1998 & 10 & 32,8 \\
\hline Joanésia & 6.517 & $30 / 02 / 1999$ & Não tem & - & - \\
\hline Mata Verde & 7.464 & 05/09/1998 & $11 / 2000$ & 01 & 46,2 \\
\hline Corinto & 24.377 & 26/07/1998 & 09/1998 & 04 & 56,6 \\
\hline Campos Altos & 13.345 & $19 / 03 / 1998$ & $06 / 2000$ & 02 & 51,7 \\
\hline Santa Maria de Itabira & 10.319 & 02/11/1997 & $04 / 1998$ & 02 & 68,9 \\
\hline Novo Cruzeiro & 30.362 & 20/10/1997 & $12 / 2001$ & 08 & 90,9 \\
\hline Chapada do Norte & 15.051 & 08/11/1997 & $12 / 2001$ & 04 & 91,7 \\
\hline Lagoa dos Patos & 4.557 & 04/04/1997 & $04 / 1998$ & 01 & 75,7 \\
\hline Arinos & 17.689 & $24 / 02 / 1997$ & 02/1999 & 02 & 35,3 \\
\hline
\end{tabular}




\begin{abstract}
ANEXO 2
Parecer da Aprovação do Comitê de Ética em Pesquisa da UFMG
\end{abstract}

UFMG

Parecer nํ ETIC 002/03

Interessados: Prof ${ }^{a}$. Dra. Maria Helena Pessini de Oliveira e

Prof. Ms. Lúcio José Vieira

Depto Materno Infantil e Saúde Pública - EEnf/UFMG

voTo:

O Comitê de Ética em Pesquisa da UFMG - COEP aprovou no dia 12 de fevereiro de 2002 o projeto de pesquisa intitulado " Reconstruindo a trajetória de mães de crianças que morreram por tétano neonatal em Minas Gerais " com a recomendação de que o Termo de Consentimento Livre e Esclarecido seja reunido em um único documento e que seja acrescentado nele o número de telefone do COEP e o dos pesquisadores. $O$ relatório final ou parcial deverá ser encaminhado ao COEP um ano após o início do projeto.

Prof. Dr. Dirceu Bartolomeu Greco Presidente da COEP 


\section{ANEXO 3}

Freqüência de tétano neonatal em Minas Gerais, entre 1997 e 2002, por DADS/município/ano

\begin{tabular}{|c|c|c|c|c|c|c|c|c|}
\hline \multirow[t]{2}{*}{ DADS } & \multirow[t]{2}{*}{ MUNICÍPIO } & \multicolumn{6}{|c|}{ ANOS } & \multirow[t]{2}{*}{ ÓBITOS } \\
\hline & & 1997 & 1998 & 1999 & 2000 & 2001 & 2002 & \\
\hline Barbacena & Catas Altas & & & 1 & & & & 1 \\
\hline Cel. Fabriciano & Iapu & & & 1 & & & & 1 \\
\hline Cel. Fabriciano & Ipatinga & & & 1 & & & & 1 \\
\hline Cel. Fabriciano & Cel. Fabriciano & & & & 1 & & & 1 \\
\hline Diamantina & Carbonita & & & & 1 & & & 1 \\
\hline Diamantina & Chapada do Norte & 1 & & & & & & 1 \\
\hline Gov. Valadares & Água Boa & & & & & & 1 & 1 \\
\hline Itabira & Santa $\mathrm{M}^{\mathrm{a}}$ de Itabira & 1 & & & & & & 1 \\
\hline Montes Claros & Espinosa & & 1 & & & & & 1 \\
\hline Montes Claros & Lagoa dos Patos & 1 & & & & & & 1 \\
\hline Montes Claros & Rio Pardo & & & 1 & & & & 1 \\
\hline Montes Claros & Rubelita & & & 1 & & & & 1 \\
\hline Montes Claros & S. João das Missões & 1 & & & & & & 1 \\
\hline Montes Claros & S. João das Missões & & & & & & 1 & 1 \\
\hline Montes Claros & S. João da Ponte & 1 & & & & & & 1 \\
\hline Montes Claros & S. João da Ponte & & & 1 & & & & 1 \\
\hline Pedra Azul & Mata Verde & & 1 & & & & & 1 \\
\hline Sete Lagoas & Corinto & & 1 & & & & & 1 \\
\hline Teófilo Otôni & Ladainha & & & & & 1 & & 1 \\
\hline Teófilo Otôni & Novo Cruzeiro & 1 & & & & & & 1 \\
\hline Teófilo Otôni & Novo Oriente & & & 1 & & & & 1 \\
\hline Teófilo Otôni & Umburatiba & & & & 1 & & & 1 \\
\hline Uberaba & Campos Altos & & 1 & & & & & 1 \\
\hline Uberlândia & Araguari & & & 1 & & & & 1 \\
\hline Unaí & Arinos & 1 & & & & & & 1 \\
\hline TOTALIZAÇÃO & & 7 & 4 & 9 & 3 & 1 & 2 & 25 \\
\hline
\end{tabular}




\section{ANEXO 4 \\ Roteiro de entrevista}

Código Identificador: Data e Local:

Início: Término:

DRS: Município:

$\square$ Área Rural $\square$ Área Urbana

$1^{\text {a }}$ Parte - Identificação

Nome: Idade:

Escolaridade: Ocupação:

Número de filhos: (a) (b)

(anteriores e posteriores ao caso em questão)

Caderneta de Vacinação: Possui? $\square$ Sim $\square$ Não

Situação vacinal (tétano):

Cartão pré-natal: Possui? $\square$ Sim $\square$ Não

Situação encontrada:

$2^{\text {a }}$ Parte - Questões norteadoras:

1. Fale sobre as gravidezes de seus filhos.

2. E seus partos, como foram?

3. A senhora se lembra de ter feito alguma coisa, durante a(s) gravidez(es), para evitar problemas para a senhora e para o bebê?

4. Alguma das suas crianças morreu? Se sim, fala um pouco sobre isso.

5. O que a senhora fazia com o umbigo de seus bebês?

6. A senhora sabe o que é o "mal-de-sete-dias" (tétano neonatal)? Se sim, fale um pouco sobre isso. 


\section{ANEXO 5}

\section{Termo de consentimento pós-informado}

Nome da pesquisa: Reconstruindo a trajetória de mães de crianças que morreram por tétano neonatal em Minas Gerais.

Pesquisador responsável: Lúcio José Vieira - Coren-MG 18.309

Orientadora: Profa. Dra. Maria Helena Pessini de Oliveira - Coren-SP 5.888

\section{INFORMAÇÕES AO CLIENTE SOBRE A PESQUISA}

Eu, Lúcio José Vieira, pesquisador responsável pelo projeto de pesquisa Reconstruindo a trajetória de mães de crianças que morreram por tétano neonatal em Minas Gerais, necessito da sua colaboração para participar desta pesquisa, como trabalho de conclusão do Programa de Pós-Graduação em Enfermagem em Saúde Pública, nível Doutorado, da Escola de Enfermagem de Ribeirão Preto da Universidade de São Paulo. Comprometo-me a informar-lhe a respeito do projeto e de seus direitos e, em caso de aceitação, solicito sua assinatura no local determinado ao final deste termo.

1. Justificativa: Necessidade de conhecer melhor como ocorre o tétano neonatal (mal-de-sete-dias) a partir de relatos de mães que o vivenciaram.

2. Objetivo: Trazer contribuições para o melhor entendimento desse problema, de modo a colaborar para a melhor formulação de propostas de ação para o seu controle.

3. Procedimentos: Não haverá procedimentos experimentais. A coleta de dados será feita por meio de entrevistas. Para tanto, solicitamos sua autorização para que ela seja gravada.

4. Riscos e desconfortos: Não estão previstos desconfortos ou riscos físicos. Não será utilizado procedimento experimental. As informações serão mantidas em sigilo.

Lúcio José Vieira

Doutorando do Programa de Pós-Graduação em

Enfermagem em Saúde Pública da Escola

Enfermagem Materno-Infantil e Saúde Pública da

Escola de Enfermagem da USP
Maria Helena Pessini de Oliveira

Profa. Dra. Do Departamento de Enfermagem da USP 


\begin{abstract}
ANEXO 6
Autorização

\section{Direitos do participante:}

1. A garantia de receber resposta a esclarecimentos e dúvidas sobre a pesquisa em qualquer momento de seu desenvolvimento.

2. A participação é voluntária e tenho a liberdade de retirar o consentimento em qualquer fase da pesquisa, sem que isto acarrete prejuízo para mim e para meus familiares.

3. A garantia de sigilo dos dados. Ninguém, além do pesquisador, terá acesso ao nome dos participantes da pesquisa.

4. Não há nenhum tipo de despesa material ou financeira durante o desenvolvimento da pesquisa, assim como não acarretará nenhum tipo de risco, dano físico e constrangimento moral.

5. Consentimento ao pesquisador para utilizar os resultados advindos da pesquisa para divulgação científica e publicações em meios especializados.

Fui informada sobre os objetivos, os procedimentos, os riscos e os benefícios desta pesquisa e, ciente dos meus direitos, autorizo a realização e a gravação das entrevistas.
\end{abstract}

Assinatura da mãe

de

de 2003 


\section{REFERÊNCIAS}

ALBERTI, V. História oral: a experiência do CPDOC. Rio de Janeiro. Fundação Getúlio Vargas, 1989. 197p.

AS PARTEIRAS DA FLORESTA. Isto É, n. 1.507, 19 ago. 1998.

AMORIM, A.C.C.; ARAÚJO, M.R.N. Legislação básica: saúde da família. Montes Claros: Unimontes, 2004. 222p.

BEMFAM. Sociedade Civil Bem-Estar Familiar do Brasil and DHS - Demographic Health Survey. Pesquisa nacional sobre demografía e saúde - 1996. Rio de Janeiro: Macro International, Inc. 1997.

BESSA, L. F.; FERREIRA, S. L. Mulheres e parteiras: Contribuição ao estudo do trabalho feminino em contexto domiciliar rural. Salvador, GRAFUBA, 1999.

BOLETIN INFORMATIVO DEL PROGRAMA AMPLIADO DE IMUNIZACIÓN. La mortalidad por tétanos neonatal. OPAS, 13 (2):5-7, 1991.

BOLTANSKI, L. As classes sociais e o corpo. 2. ed. Rio de Janeiro: Graal,1984.

BRASIL Ministério da Saúde. Secretaria Médica. Programa de saúde materno infantil. Brasília, 1974.

BRASIL. Ministério da Saúde. Divisão Nacional de Educação em Saúde. Ação educativa nos serviços básicos de saúde. Educação e Saúde, 2. Brasília, 1981.

BRASIL Ministério da Saúde. Assistência Integral à Saúde da Mulher: Base de ação programática. Brasília. Centro de Documentação do Ministério da Saúde, 1984. p. 6 
BRASIL. Ministério da Saúde. O programa nacional de imunizações: 15 anos, uma análise crítica. Brasília: Secretaria Nacional de Ações Básicas de Saúde, 1989. 52p.

BRASIL Ministério da Saúde. Divisão Nacional de Saúde Materno Infantil. Relatório de atividades 1990. Brasília: Secretaria Nacional de Assistência à Saúde. Departamento Nacional de Programas de Saúde. Ministério da Saúde, 1990 (mimeo.).

BRASIL Ministério da Saúde. Poliomielite: informe semanal. Brasília, 1991, v. 6, n. 4, jan. 1991.

BRASIL. Ministério da Saúde. Fundação Nacional de Saúde. Departamento de Operações Coordenação da Saúde da Comunidade. Programa de saúde da família: dentro de casa. Brasília, DF, 1994.

BRASIL Ministério da Saúde. Coordenação de Saúde Materno Infantil. Programa de assistência integral á saúde da mulher - Assistência pré-natal. 3. ed. Brasília: Ministério da Saúde, 1997a. 62p (Normas e manuais técnicos).

BRASIL. Anuário estatístico brasileiro. Edição 1996. Rio de Janeiro: FIBGE, 1997b.

BRASIL. Ministério da Saúde. Programa nacional de imunizações: PNI 25 anos. Brasília: Fundação Nacional de Saúde. 1998a. 88p.

BRASIL. Guia de vigilância epidemiológica. Brasília: Centro Nacional de Epidemiologia. FNS. 1998 b.

BRASIL. Ministério da Saúde. Evolução temporal das doenças de notificação compulsória no Brasil de 1980 a 1998. Fundação Nacional de Saúde. Centro Nacional de Epidemiologia. Boletim Epidemiológico, ano III, ed. especial, 1999a. p. 24-25.

BRASIL. Fiocruz. Assistência perinatal e neonatal no Brasil. Radis/Tema, 17 fev. 1999b.

BRASIL. Ministério da Saúde. Assistência pré-natal: manual técnico. 3. ed. Brasília, 2000. 
BRASIL Ministério da Saúde. Manual de normas de vacinação. 3. ed. Brasília: Fundação Nacional de Saúde. 2001.

BRASIL. Ministério da Saúde. Evolução do plano de eliminação do tétano neonatal no Brasil - Situação atual e diretrizes para 2003. Brasília:Fundação Nacional de Saúde. Centro Nacional de Epidemiologia. 2003. 14p.

BRASIL. Secretaria de Vigilância à Saúde. Brasil, 2004. Disponível em:<http://dtr2001. saude. gov. br/svs/epi/situacao_doencas/tetano_neonatal. pdf

BUSS, P. M. Assistência hospitalar no Brasil (1984-1991): uma análise preliminar baseada no sistema de informação hospitalar do SUS. Informe Epidemiológico do SUS, p. 5-17, mar/abr 1993.

CAMPOS, T. P. ; CARVALHO, M. S. Assistência ao parto no município do Rio de Janeiro: Perfil das maternidades e o acesso da clientela. Cadernos de Saúde Pública, Rio de Janeiro, v. 16, n. 2 , p. $411-420.2000$

CARVALHO, I; CHACHAM, A. S.; VIANA, P. Parteiras tradicionais e suas práticas na área rural de Pernambuco - 1996. In: ENCONTRO NACIONAL DE ESTUDOS POPULACIONAIS, XI, 1998, Caxambu, MG. Anais... ABEP, 1998. p. 873-88.

CENTRO LATINO-AMERICANO DE PERINATOLOGIA E DESENVOLVIMENTO HUMANO (CLAP) - OPS/OMS, Montevidéu. Saúde perinatal. Tradução de Thais de Azevedo. Brasil, 1988. Tradução de artigos selecionados de Salud Perinatal, boletim do CLAP, 179p.

COSTA, A M. O PAISM: uma política de Assistência integral à saúde da mulher a ser resgatada. CCR/ Comissão de Cidadania e Reprodução. São Paulo, dez. 1992.

DIAS, M. D. Mãos que acolhem vidas: as parteiras tradicionais no cuidado durante o nascimento em uma comunidade nordestina. 2002. 204f. Tese (Doutorado) - Escola de Enfermagem da Universidade de São Paulo, São Paulo, 2002.

DOMINGUES, R. M. S. M.; SANTOS, E. M.; LEAL, M. C. Aspectos da satisfação das mulheres com a assistência ao parto. Cadernos de Saúde Pública, v. 20, n. 1, p. 552-562, 2004. 
FARR, M. R. Representações sociais: a teoria e sua história. In: JOVCHELOVITCH, S.; GUARESCH, P (Org.). Textos em representações sociais. Petrópolis: Vozes, 1994. p. 3159.

FEKETE, M. C. Estudo da acessibilidade na avaliação dos serviços de saúde. Projeto GERUS/Desenvolvimento Gerencial das Unidades de Saúde do Distrito Sanitário. Brasília: Fundação Nacional de Saúde. 1995. p. 177-83.

FERREIRA, A. B. H. Novo Aurélio século XXI: o dicionário da língua portuguesa. 3. ed. Rio de Janeiro: Nova Fronteira, 1999.

FOCACCIA, R.; VERONESI, R. Tétano. In: FARHAT, C. K. Fundamentos e prática das imunizações em clínica médica e pediatria. 3. ed. São Paulo: Atheneu, 1989. p. 65-73.

FORMIGA, I F N Filho. Políticas de saúde reprodutiva no Brasil: uma análise do PAISM. In: GALVÃO, L. DIAS, J (Org.). Saúde sexual e reprodutiva no Brasil. São Paulo: HUCITEC/Population Council, 1999. p. 151-62.

GALAZKA, A.; STROH, G. Guidlines on the community - Based survey on neonatal tetanus mortality. Ginebra: OMS, 1986. Document EPI/GEN/86/8.

GARRET, A. A entrevista, seus princípios e métodos. 8. ed. Rio de Janeiro: Agir, 1981.

GERA, S. C. Oportunidades perdidas de vacinação: um indicador da assistência integral à saúde da criança. 1998. 186f. Dissertação (Mestrado) - Escola de Enfermagem de Ribeirão Preto, Universidade de São Paulo, Ribeirão Preto, 1998.

GRAMSCI, A. A concepção dialética da história. Trad. bras. Carlos Nelson Coutinho. 8. ed. Rio de Janeiro: Civilização Brasileira, 1989.

JUCÁ, J.; MOULIN, N (Org.). Parindo um mundo novo. Janete Capiberibe e as parteiras do Amapá. São Paulo: Cortez, 2002. 125p.

LE BRETON, D. Que sais-je? La sociologie du risque. France: Presses Universitaires de 1995. 127p. 
LEFÈVRE, F. ;LEFÈVRE, A. M. C. Os novos instrumentos no contexto da pesquisa qualitativa. In: LEFÉVRE, F.; LEFÉVRE, A. M. C.; TEIXEIRA, J. J. V (Org.). O discurso do sujeito coletivo - Uma nova abordagem metodológica em pesquisa qualitativa. 1. ed. Caxias do Sul: EDUCS, 2000, p. 11-35.

LEMOS, J. A. C.; RODRIGUES, R. C. M. Plano de eliminação do tétano neonatal. CORENMG: Presente, set./nov. 2003, p. 8-9.

LEROY, O.; GARENNE, M. Risk factors of neonatal tetanus in Senegal. International Journal of Epidemiology. 20 (2): 521-26, 1991.

LOYOLA, M. A. Médicos e curandeiros: conflito social e saúde. São Paulo: Difusão Editorial, 1984. 198p.

LUDKE, M.; ANDRÉ, M. E. D. A. Pesquisa em educação: abordagens qualitativas. São Paulo: EPU, 1986. 99p.

MACHADO, K. 10 anos do PSF: Saúde da família se firma como estratégia permanente do SUS. Radis, p. 10-11, 23 jul. 2004.

MARQUES, A. F. B. Teias de renda: sutilezas e evidências que se imbricam na capacitação dos agentes de saúde - Estudo de caso em Icapuí, Ceará. Fortaleza. 2001. 116f. Dissertação (Mestrado) - Universidade Estadual do Ceará, Fortaleza, 2001.

MÉDIC, A. C. Uma década de SUS (1988-1998): progressos e desafios. In: GALVÃO L. DÍAZ, J (Org.). Saúde sexual e reprodutiva no Brasil. São Paulo: Hucitec: Population Council, 1999. p. 104-150.

MELGAARD, B.; MUTE, D. M.; KIMANI, G. A cluster survey of mortality due to neonatal tetanus in Kenya. International Journal of Epidemiology, 17 (1): 174-177, 1988.

MENDES, L. C.; CAVALCANTI, M. P. Experiências com parteiras no norte de Minas. Belo Horizonte, 1989. 80f. Mimeo. 
MENEGHEL, S. N.; DANIILEVICZ, N.; KMETZSEH, C.; VON MUHLEN, D. et al. Inquérito de morbimortalidade do tétano neonatal no município de Nonoai. Rio Grande do Sul, 1988. Relatório de Pesquisa, 1988. 19f. Mimeo.

MINAS GERAIS. Secretaria de Estado da Saúde. Situação do tétano neonatal. Belo Horizonte: Coordenadoria de Doenças Controláveis por Imunização, 1999 (Relatório Técnico).

MINAYO, M. C. S. O desafio do conhecimento. Pesquisa qualitativa em saúde 3. ed. São Paulo-Rio de Janeiro: Hucitec-Abrasco, 1994. 269p.

MIURA, E. Tétano neonatal. In: FARHAT, C. K. et al. Infectologia pediátrica. São Paulo: ATHENEU, 1994. p. 214-16.

MONTEIRO, C. A.; IUNES, R. F.; TORRES, A. M. A evolução do país e de suas doenças: Síntese, hipóteses e implicações. In: MONTEIRO, C. A (Org.). Velhos e novos males da saúde no Brasil: a evolução do país e de suas doenças São Paulo: Hucitec/Núcleo de Pesquisas Epidemiológicas em Nutrição e Saúde, USP, 2000a. p. 349-356.

MONTEIRO, C. A.; MONDINI, L e COSTA, R. B. L. Evolução da mortalidade infantil e do retardo de crescimento nos anos 90: Causas e impacto sobre as desigualdades regionais. In: MONTEIRO, C. A (Org.). Velhos e novos males da saúde no Brasil - A evolução do país e de suas doenças. São Paulo: Hucitec/Núcleo de Pesquisas Epidemiológicas em Nutrição e Saúde, USP, 2000b.p. 393-420.

OLA, P.; D’AULAIRE, E. A tarefa do doutor tétano. Seleções Reader's Digest, n. 44-51, jun. 2003.

OSIS, M. J. M. D. PAISM: um marco na abordagem da saúde reprodutiva no Brasil. Cadernos de Saúde Pública, v. 14, supl. 1, p. 25-32, 1998.

POLIS. Parteiras tradicionais do Amapá. Disponível em: http://www. polis. org. br/publicações. Acesso em: 12 ago. 2002.

ROCHA, J. M. Como se faz medicina popular. Petrópolis: Vozes, 1985. p. 63 
SCHRAMM, J. M. A.; SANCHES, O.; SZWARCWALD, C. L. Análise da mortalidade por tétano neonatal no Brasil (1979-1987). Cadernos de Saúde Pública, Rio de Janeiro, v. 12, n. 2, p. 217-24, 1996.

SERRUYA, S. J.; CECATTI, J. G.; LAGO, T. G. O programa de humanização no pré-natal e nascimento do Ministério da Saúde no Brasil: resultados iniciais. Cadernos de Saúde Pública, Rio de Janeiro, v. 20 n. 5, p. 1.281-1.289, 2004.

STARFIELD, B. Atenção Primária: o equilíbrio entre necessidades de saúde, serviços e tecnologia. Brasília: UNESCO, Ministério da Saúde, 2002.

TANAKA, A. C. d'A. Saúde materna e saúde perinatal: relações entre variáveis orgânicas, socioeconômicas e institucionais. 1986. Tese (Doutorado) - Faculdade de Saúde Pública da Universidade de São Paulo, São Paulo, 1986.

TANAKA, A. C. d'A; MITSUIKI, L. Estudo da magnitude da mortalidade materna em 15 cidades brasileiras. São Paulo: Unicef, 1999.

TAVARES, W. Contribuição ao conhecimento da distribuição natural do Clostridium tetani no Estado do Rio de Janeiro. 1985. 235f. Tese (Doutorado) - Faculdade de Medicina, UFF, Niterói, 1985.

TAVARES, C. M. de M.; TEIXEIRA, E. R. Trabalhando com as representações sociais na enfermagem. In: GAUTHIER, J. H. M.; CABRAL, I. E.; SANTOS, I.; TAVARES, C. M. de M (Org.). Pesquisa em enfermagem: novas metodologias aplicadas. Rio de Janeiro: Guanabara Koogan, 1998. p. 51-59.

TRIVIÑOS, A. N. S. Introdução à pesquisa em ciências sociais: a pesquisa qualitativa em educação. São Paulo: Atlas, 1987.

UNICEF. Guidilines for monitoring the availability and use of obstetric services. Nova York:UNICEF/OMS/FNUAP, 1997.

VERONESI, R.; FOCACCIA, R.; MAZZA, C. C. Tétano. In: VERONESI, R. Doenças infecciosas e parasitárias. 8. ed. Rio de Janeiro: Guanabara Koogan. 1991. p. 447-66. 
VICTÓRA, C. G.; GRASSI, P. R.; Schmidt, A. M. Situação de saúde da criança em área da região Sul do Brasil, 1980-1992: tendências temporais e distribuição espacial. Revista de Saúde Pública, v. 28, p. 423-432, 1994.

VICTÓRA, C. G. Pesquisa qualitativa em saúde: introdução ao tema. Porto Alegre: Tomo Editorial, 2000. p. 33-43.

VIEIRA, L. J. Contribuição ao estudo epidemiológico do tétano neonatal no Estado de Minas Gerais de 1989 a 1996: um enfoque de risco. 1998. 124f. Dissertação (Mestrado) Escola de Enfermagem da Universidade Federal de Minas Gerais, Belo Horizonte, 1998.

WHO. International statistical classification of diseases and related problema. 2. ed. Genebra, 1992. v. 1.

WHO. Weekly Epidemiology Record, v. 38, p. 277-282, 1993. 